DEPARTMENT OF THE INTERIOR UNITED STATES GEOLOGICAL SURVEY GEORGE OTIS SMITH, DIRECTOR

BULLetin 508

\title{
THE ONONDAGA FAUNA OF THE
} ALLEGHENY REGION

BY

E. M. KINDLE

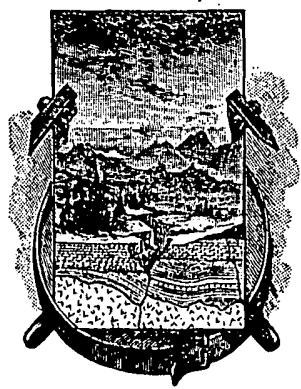

WASHINGTON

GOVERNMENT PRINTING OFFIOE

1912 



\section{CONTENTS.}

Introduction . Page.

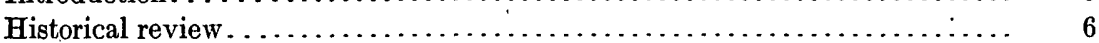

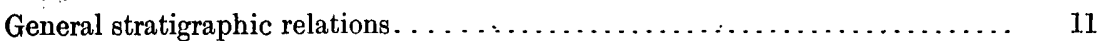

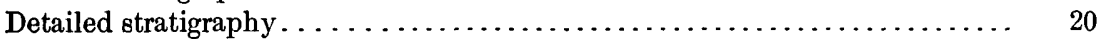

New York. . . . . . . . . . . . . .

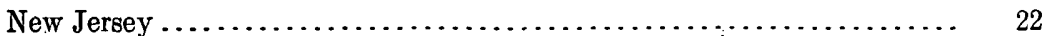

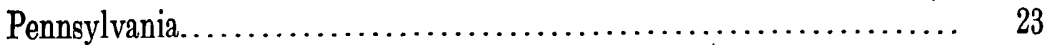

Maryland................................................. 35

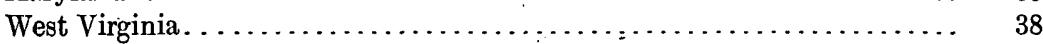

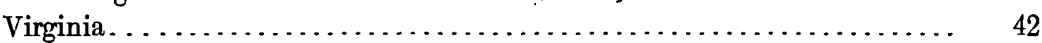

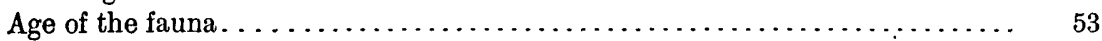

Paleogeographic significance of the fauna.........................., 63

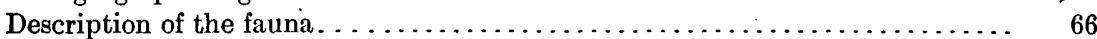

Colenterata........................................... 66

Echinodermata ......................................... 67

Vermes............................................. 67

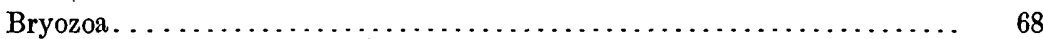

Brachiopoda........................................... 69

Pelecypoda............................................ 87

Gastropoda. . . . . . . . . . .

Pteropoda............................................ 103

Cephalopoda........................................ 106

Trilobita............................................. 107

Ostracoda............................................... 113

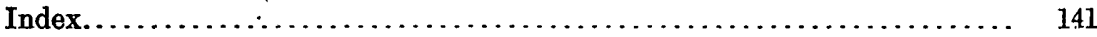

\section{ILLUSTRATIONS.}

Plate I. Chart showing sections of Onondaga formation from New York to Vir-

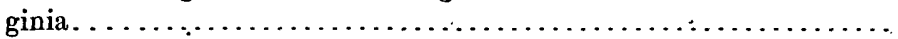

II-XIII. Onondaga fossils.......................... 117-140 



\title{
THE ONONDAGA FAUNA OF THE ALLEGHENY REGION.
}

\author{
By E. M. KINDLE.
}

\section{INTRODUCTION.}

The importance of the Onondaga limestone as a datum plane was early recognized in New York State. It was easily identified by the peculiar black cherts of some of its beds, and Amos Eaton made important use of it in his early surveys, before the characteristic fossils of this or any other American formation were known. As early as 1839 he wrote to Prof. Silliman regarding its importance to the field geologist as follows:

I used this rock as the line of reference for other strata, as strangers in New York City use Broadway as a place of reference for other streets. *** Its vast extent and the important disposition it holds among North American rocks will make it very useful to geological surveyors. ${ }^{1}$

From Hudson River to Lake Erie the Onondaga limestone is represented by a zone of frequently recurring outcrops across central New York State. Passing under Lake Erie, the fauna reappears in rocks of the same lithologic facies in northern and central Ohio, and reaches as far west as Louisville. The most westerly recorded appearance of the fauna is at the Bake Oven, in southwestern Illinois, so that it has an east-west extension of about 1,000 miles. In sharp contrast with this considerable westerly extension of the Onondaga fauna beyond its type region in eastern New York is the comparatively insignificant southerly extension of the fauna and formation as it has been generally recognized. The formation barely crosses Delaware River, according to most of the papers dealing with the stratigraphy of the Devonian in the Allegheny region, which give it a north-south extension of scarcely 200 miles. This insignificant southerly extension of a fauna which has been recognized as so persistent in a westerly direction seems more surprising when it is recalled that nearly all the other faunas characterizing the major divisions of the New York Devonian section have been traced southward from New York entirely across Pennsylvania into the Virginias. Thus, it is seen that the prevailing conception of the Onondaga fauna, which presumes its

\footnotetext{
1 Eaton, Amos, Cherty lime rock, or Corniferous lime rock, proposed as the line of reference for State
} geologists of New York and Pennsylvania: Am. Jour. Sci., 1st ser., vol. 36, 1839, pp. 62, 64. 
absence south of New York, gives to it an anomalous position as compared with the other important faunas of the Devonian section

- of New York. The evidence which I have gathered during several seasons of field work in the Allegheny region indicates that this conception is not well founded, and that the southerly extension of the Onondaga fauna is quite comparable in distance with its westerly extension. Faunal and stratigraphic details of this evidence appear in the following pages. My field studies have shown that the Onondaga fauna in the Allegheny region extends far south of the area in which nearly pure limestones were deposited during Onondaga time, into a region where shale-forming sediments partly or completely dominated those of calcareous type. This fauna has been found in nearly all the sections studied, from New York to Tennessee. Before these sections are discussed, a brief account of the opinions and conclusions of preceding authors on the occurrence of the Onondaga fauna south of New York will be presented.

\section{HISTORICAL REVIEW.}

In the county reports of the Second Pennsylvania Geological Survey the beds lying immediately above the Oriskany are referred to the Marcellus. However, in at least one of the earlier papers dealing with the Devonian section of Pennsylvania, the shale and limestone bands at the base of the Marcellus are referred to the "Upper Helderberg," or Onondaga. Ashburner includes in his section above the Oriskany 60 feet of shale and thin limestone bands which he assigns to the "Upper Helderberg (Post-Meridian) limestone.". He gives, however, no paleontologic data bearing on this correlation.

Although some of the earlier writers on the geology of Pennsylvania had included the "Corniferous" (Onondaga) in sections noted in that State, the opinion of Claypole that it was absent seems to have been acquiesced in by almost all later writers. Claypole stated his opinion very positively and asserted that it rested on paleontologic data, and the positiveness of his statement gave it weight with contemporary and succeeding writers. The correlation proposed by Claypole with reference to the Perry County section for the beds above the Oriskany was expressed as follows:

Overlying the Oriskany sandstone is a series of shales and limestones which paleontological evidence places in the Marcellus division of the Hamilton group. ${ }^{2}$

He does not, however, give the paleontologic evidence on which this correlation rests.

${ }^{1}$ Ashburner, C. A., A measured section of the Paleozoic rocks of central Pennsylvania from the top of the Allegheny River coal series down to the Trenton limestone: Proc. Am. Philos. Soc., vol. 16, 1877, pp. 1-19.

2 Claypole, E. W., A preliminary report on the paleontology of Perry County ${ }_{\llcorner}$etc.]: Second Geol. Survey Pennsyliania, Rept. F2, 1885, p. 64. 
Elsewhere Claypole gives several sections showing alternating thin bands of limestone and dark shale, which he states afford as good evidence on stratigraphic grounds for their reference to the Marcellus as to the "Corniferous." This reference he regards as confirmed by the presence of Marcellus fossils in several of the lower beds of shale, but these are not listed. Claypole's opinion of the correlation of this limestone with the Onondaga is expressed in the following quotation:

The limestone in question [thin beds in lower "Marcellus"] has been regarded as the representative of the Corniferous formation of the New York series, solely on account of its position at the base of the Marcellus black shale. But no trace of the great deposits of flint which characterize the horizon in New York are found in Perry County. Nor have any Corniferous fossils afforded the paleontologist satisfactory evidence of the correspondence of the two strata. ${ }^{1}$

Four years after the publication of the Perry County report the catalogue of the State Museum collections appeared, which contains Claypole's lists ${ }^{2}$ of Perry County fossils by localities. This catalogue includes several short lists of fossils from strata variously designated "Marcellus limestone," "Marcellus beds," "Marcellus shale," or "Marcellus formation." These lists are composed largely of unnamed species and species without stratigraphic significance, like Atrypa reticularis and Ambocelia umbonata. They contain also the species Anoplotheca acutiplicata ${ }^{3}$ and Dalmanites myrmecaphorus?.4 As they include these two Onondaga species, Claypole's lists can hardly be said to support his contention that the Onondaga is absent from the Perry County section.

In 1889 T. Rupert Jones described two new species of ostracodes from beds overlying the Oriskany in Perry County, Pa. Accepting Claypole's opinion of the age of these beds Jones refers them to the "noncalcareous shale of the Marcellus limestone." 5

Lesley ${ }^{6}$ did not agree with Claypole's declaration that the Onondaga formation was unrepresented in Pennsylvania. His argument for its presence in central Pennsylvania included no paleontologic evidence, however, and, being based mainly on the principle of the supposed parallelism of the strata, has received much less consideration than the opposite view, advanced by Claypole.

All the recent writers who discuss or refer to the lower part of the Devonian section of Pennsylvania have followed Claypole in assuming that the Onondaga formation and fauna are absent from Pennsylvania sections which expose the lower part of the Devonian, except in the immediate vicinity of the New Jersey boundary. This view is

1 Op. cit., p. 261.

\& Pennsylvania Geol. Survey, Rept. D3, 1889, pp. 123, 174.

I Idem, p. 171.

Idem, p. 131.

- Jones, T. R., On s.ome Paleozoic ostracodes from Pennsylvania: Am. Geologist, vol. 4, 1889, p. 338.

Q Geol. Survey Pennsylvania, Summary Rept., vol. 2, 1892, pp. 1143-1195. 
expressed by Ulrich and Schuchert in their paper on Paleozoic seas and barriers." These authors conceived that land surfaces existed throughout the "Cumberland basin from the end of Oriskany time to the initiation of Marcellus sedimentation."

Schuchert's first paleographic map of Onondaga time ${ }^{2}$ limits the Onondaga sea to the northern third of the State, the region of the present outcrops of the lower part of the Devonian ärd the territory to the south and southeast of them being shown as a land area in Onondaga time. In a later map of the "Middle Onondaga" sea by Schuchert ${ }^{3}$ its southern shore is drawn somewhat farther south but still well to the north of the Maryland line.

In discussing the Lower Devonian formations of Maryland Schuchert ${ }^{4}$ states that "during Upper Oriskany time sedimentation was again general and continued until the close of the Maryland Oriskanian. Then a land condition prevailed in the basin south of middle Pennsylvania throughout Esopus and Onondaga time."

Both Prosser ${ }^{5}$ and $\mathrm{O}^{\prime} \mathrm{Harra}^{6}$ have considered the lower part of the shale formation that follows the Oriskany sandstone in Maryland as representing in a general way the Marcellus of New York, with which they correlate it.

Prosser ${ }^{7}$ reports 21 species, without listing them, from the lower 500 feet of the Romney shale of Maryland and concludes that the "correlation of this Maryland black shale with the Marcellus of New York appears to be fairly well sustained." In this paper Prosser ${ }^{8}$ divides the Romney formation of Maryland into two members, called Hamilton beds and Marcellus shale.

In. writing the history of Maryland during Paleozoic time Willis assumed that the eastern shore of the Onondaga sea lay somewhere west of the Allegheny Mountains. He regarded the whole of the Romney or "black shale" as of later age than the Onondaga, and stated $^{\theta}$ that "its distribution corresponds to an eastward and southeastward migration of the coast from the shore of the Corniferous gulf over the low marshes of Appalachia."

Schuchert also assumed a hiatus at the top of the Oriskany-a break extending over southern Pennsylvania and across Maryland-as he

\footnotetext{
1 Rept. New York State Paleontologist for 1901, 1902, p. 652.

2 Schuchert, Charles, On the faunal provinces of the Middle Devonic of America and the Devonic coral subprovinces of Russia, with two paleographic maps: Am. Geologist, vol. 32, 1903, Pl. XX.

3 Schuchert, Charles, Paleogeography of North America: Bull. Geol. Soc. America, vol. 20, 1910, pl. 75.

- Schuchert, Charles, On the lower Devonic and Ontaric formations of Maryland: Proc. U. S. Nat. Mus., vol: 26,1903, p. 114.

6 Prosser, Charles, Description and correlation of the Romney formation of Maryland: Jour. Geology, vol. 12, 1904, pp. 361-372.

6 O'Harra, C. C., The geology of Allegany County: Maryland Geol. Survey, Allegany County, 1900, p. 103.

7 Op. cit., p. 364 .

8 Idem, pp. 362-367.

๑ Willis, Bailey, Maryland Geol. Survey, special publication, vol. 4, pt. 1, 1900, p. 60.
} 
indicates by the statement that no Esopus, Schoharie, or Onondaga deposits occur in Maryland or farther south. ${ }^{1}$

In the area mapped by N. H. Darton in Virginia and West Virginia the lowest beds of the Romney, which I refer to the Onondaga, were considered to represent the Marcellus. Concerning the fossils in the lower part of the Romney, Darton " states: "Those in the lowest beds comprise some species characteristic of the Marcellus."

The papers of J. J. Stevenson ${ }^{3}$ are among the first contributions to the correlation of the rocks of southwestern Virginia with those of New York. The Chemung fauna is the earliest Devonian fauna of which he furnished definite evidence. ${ }^{4}$ Although he referred the shales below the strata containing the Chemung fauna to the Hamilton, ${ }^{5}$ he recorded no Hamilton fossils. The "Corniferous" (Onondaga) he stated to be absent from the area studied by him in southwestern Virginia. ${ }^{\circ}$

The earliest suggestion of an Onondaga horizon in Virginia known to me appears in a paper by H. S. Williams, ${ }^{7}$ who says:

The next question arising was as to the age of the base of the black shale. The study of the Big Stone Gap sections also threw light on this problem. On the Kentucky side of the Cumberland Channel, as well as on the Appalachia side, there are frequently represented at the base of the black shales beds of brown iron ore. About Big Stone Gap this brown ore contains corals which appear to be of Corniferous age, and below is a sandstone capping the Helderberg limestone. At a single locality, under the woolen mill on the bank of the east branch of Powell River east of Big Stone Gap, in the place of the ore the limestone is quite filled with corals in place, followed immediately by the black shales with no intervening iron ore. This seems to fix the date of the beginning of the black shales for this region at an horizon closely corresponding to that of the Marcellus shale in the New York section.

As no evidence in support of this opinion beyond that contained in the above lines appears in Williams's paper, it may be regarded as having more suggestive than evidential value.

Four quadrangles in southwestern Virginia, mapped by M. R. Campbell, ${ }^{8}$ include a portion of the territory in which the Onondaga fauna occurs. Although Campbell makes no specific mention of this fauna and was evidently not aware of its occurrence in the region, unlike some of the authors mentioned in this review, he does not deny its presence. On the contrary, his columnar sections indicate

\footnotetext{
1 Proc. U. S. Nat. Mus., vol. 26, 1903, p. 422.

2 Monterey folio (No. 61), Geol. Atlas U. S., U. S. Geol. Survey, 1899, p. 4.

a Notes on the geology of Wise, Lee, and Scott councies, Va.: Proc. Am. Philos. Soc., vol. 19, 1882, pp. 87-107; A geological reconnaissance of parts of Lee, Wise, Scott, and Washington counties, Va.: Idem, pp. 219-262; Notes on the geological structure of Tazewell, Russell, Wise, Smythe, and Washington counties of Virginia: Idem, vol. 22, 1885, pp. 114-160.

4 Proc. Am. Philos. Soc., vol. 22, 1885, p. 139.

B Idem, p. 140.

- Idem, vol. 19, 1882, p. 233.

I On the southern Devonian formations: Am. Jour. Sci., 4th ser., vol. 3, 1897, p. 399.

${ }^{8}$ Estillville (No. 12), Pocahontas (No. 26), Tazewell (No. 44), and Bristol (No. 59) folios, Geol. Atlas U. S., U. S. Geol. Survey.
} 
no stratigraphic break within the Devonian and hence provide for the possible discovery of any one or all of the Devonian faunas.

The sections studied in my earlier work in the Allegheny region in Pennsylvania did not extend down to the horizon of the Onondaga limestone or the Marcellus shale. Some of the sections which were studied in Virginia in this earlier work, however, included what Williams ${ }^{1}$ considered, on rather meager evidence, it must be admitted, an early Middle Devonian horizon. Grabau, ${ }^{2}$ who found this evidence unfavorable to his hypothesis of a southward transgression of black shale in the Allegheny region, concluded that "the evidence adduced points to an early Upper Devonic age of the black shales at Hot Springs, rather than a lower Middle Devonic, as advocated by Williams." Farther north in Maryland, however, where the theory of the southward transgression of the black shale must assume an earlier age for these beds than in central Virginia, the black shale is, according to Grabau, "clearly of the age of the Marcellus of New York and in part it also represents the Onondaga." For the statement that the black shale in part represents the Onondaga no evidence is offered. Though correct, this opinion appears to have been deduced from the broader inference of the southward transgression of the black shale.

Schuchert, ${ }^{3}$ in a review of the paper by Williams and Kindle, just cited, stated that the faunules in question "are decidedly more Marcellus than Onondaga." Schuchert's unwillingness to admit the Onondaga age of any part of the Virginia section appears to have been due in part to his doubt of the correctness of my identification of Anoplotheca acutiplicata. With reference to this identification Prosser, ${ }^{4}$ in a later review of the same paper, regarded this identification as probably correct, "for the same species occurs near the base of the black shale or Marcellus member of the Romney formation in western Maryland. The Maryland specimens were examined by Dr. John M. Clarke, so that no question can be raised regarding their specific identity." It should be stated here that the collections on which the determination of the Onondaga age of the Virginia sediments was based were small and not fairly representative. In succeeding pages it will be shown that Anoplotheca acutiplicata and other Onondaga species occur not only in Virginia but in the West Virginia, Maryland, and Pennsylvania sections to the north.

R. S. Bassler ${ }^{5}$ has published several sections in southwestern Virginia, which include the beds below the black shale. Although his

1 Williams, H. S., and Kindle, E. M., Contributions to Devonian paleontology, 1903: Bull. U. S. Geol. Survey No. 244, 1905.

2 Grabau, A. W., Bull. Geol. Soc. America, vol. 17, 1906, p. 609.

3 Am. Jour. Sci., 4th ser.; vol. 19, 1905, p. 461.

- Am. Geologist, vol. 36,1905 , p. 50.

6 The cement resources of Virginia west of the Blue Ridge: Bull. Virginia Geol. Survey No. 2-A, 1909, pp. 258-273. 
paper is economic, it gives much valuable detail concerning the faunas of the limestones. The paleontologic notes do not extend to the Onondaga fauna, however, and the paper is mentioned here only because of its contribution to our knowledge of the beds which lie below those containing the Onondaga fauna.

The latest reference to the Onondaga fauna in the Allegheny region which has come under my notice occurs in a paper by Weller, ${ }^{1}$ whose observations, however, are of a generalized character, intended to summarize the more salient points in the several papers which have appeared on the faunas discussed. Weller's remarks on the geographic distribution of the Onondaga fauna in the Appalachian region differ from my conclusions in much the same way as those of the other authors already noted. It should be added, however, that Weller's paper does not undertake to give any new data on the region discussed, and the discrepancy between his conclusions and mine, as well as that between some other statements which have been noted and the facts which will be cited, can probably be traced back to Claypole's declaration that the Onondaga fauna is absent in most of the region south of New York.

\section{GENERAL STRATIGRAPHIC RELATIONS.}

Before considering the stratigraphic relations of the beds and fauna which constitute the subject of this paper, it is desirable to refer briefly to the general conditions controlling sedimentation during the Devonian period in what may be called the Allegheny province. The greater part of the province was occupied during Devonian time by a broad arm of the sea, known as the Appalachian Gulf. Along the eastern border of this gulf were deposited the 5,000 to 10,000 feet of Devonian sediments found in the Allegheny region.

Although the general tendency of earth movement in this region was toward subsidence, there were occasional intervals of uplift when the sea became shallow, as is shown by the ripple marks of the Portage. At other stages, such as the Genesee, with its fine black shales without wave marks, there was evidently deeper water. The great thickness of clastic sediments comprised in the Devonian system of this region.was derived largely from the land area that lay immediately east of the Appalachian Gulf and is known as Appalachia.

Faunal and stratigraphic studies in the Appalachion province should proceed with a clear recognition of the essential factors which determined in large degree the character of the faunas and sediments. The most important factors controlling the uniformity of a fauna are temperature, ocean currents, character of sedimentation, depth of

1 Weller, Stuart, Correlation of the Middle and Upper Devonian and the Mississippian faunas of North America: Jour. Geology, vol. 17, 1909, p. 261: 
water, food supply, and land barriers. Any considerable change in any one of these factors will give rise to a corresponding difference in the character of a fauna. These factors differ in relative importance in different regions. The factors of prime importance with reference to the character of the formations are source of materials, distance from shore line, and means of transportation. It is clear that land areas of crystalline rocks will afford sediments of different types from those composed of noncrystalline rocks, and that rivers in limestone lands will carry to the sea sediments differing widely. from those of rivers that are eroding in areas occupied by sandstone or quartzite. Likewise we may expect the sediments representing any one interval of time not only to differ with difference in their distance from the shore line of the sea in which they were deposited but also to differ according to their distance from river mouths and, to some extent, with reference to their relation to ocean currents. Allusion to principles so elementary as these might appear superfluous were it not for the fact they have obviously been lost sight of by the authors of some papers on stratigraphy, who appear to suppose that differences between contemporaneous faunas can be accounted for only by assuming the presence of land barriers. Quite as often we find the naïve reasoning that the absence in a particular area of a type of sediments which is generally characteristic of a particular formation indicates there a hiatus representing the time during which that formation was deposited in the region where its peculiar type of sediment is found. Such an assumption fails to take cognizance of the important stratigraphic principle that lithologic character remains uniform only over the area in which the sediments were uniform in character and amount. It is to be expected that the amount and kind of sedimentation will vary at a much more rapid rate in a direction normal to the coast than parallel to it. The areas of uniformity in sedimentation are in general parallel to the old shore lines of the Devonian sea.

Many of the Devonian formations of New York and the Allegheny region well illustrate this principle, thinning and grading laterally into very unlike formations of finer texture toward the west, while retaining a uniform character for a much greater distance toward the south and southwest. The Hamilton formation affords â notable example. In eastern Pennsylvania it inclu des much coarse sandstone and even some conglomerate. Farther west every trace of these coarse clastic materials has disappeared from the sections, and the thickness of the formation has been reduced about one-half. In the eastern ranges of the Alleghenies, however, sandstones are conspicuous in the Hamilton in three States. 
The Devonian formations occur in broad belts, crossing New York from east to west. In following these formations westward across the State of New York the faunal as well as the lithologic facies of some of them have been found to change completely. The contrast between the lithologic facies of the Portage formation in eastern and in west-central New York is less striking than that between its faunal facies in the two districts, which are totally unlike.

Although the Devonian formations as a rule retain their lithologic and faunal integrity for a much greater distance parallel to the old coast line of the Appalachian gulf than at right angles to it, still nearly all of them undergo great changes, both lithologic and faunal, in their southern extension. The lithologic peculiarities of formations which at the north are sharply differentiated tend to converge toward a uniform type of sediments at the south.

To illustrate this differentiation of the Devonian sediments into a greater number of lithologic units at the north than at the south, the Devonian geologic section of New York and of Maryland, as given by the geological surveys of the two States, may be compared. The New York section shows fourteen distinct divisions, ${ }^{1}$ not including some minor subdivisions, whereas the Maryland section shows but five subdivisions. ${ }^{2}$ This great difference in the number of formations recognized in New York and Maryland is due primarily neither to comparative incompleteness of the Maryland sedimentary record nor to lack of discrimination on the part of the Maryland geologists, but it represents a tendency to lithologic uniformity toward the south, which begins to be prominent only in Maryland. This tendency of the Middle Devonian formations above the Oriskany sandstone to lose their lithologic distinctions is shown in the following table, which indicates their stratigraphic relations and geographic distribution in the Allegheny region. With the exception of the Onondaga, which has generally been considered absent south of New York, the stratigraphic nomenclature of the table is that which has been used in United States Geological Survey folios and recent State Survey reports. This table illustrates vividly the preceding remarks regarding the well-marked lithologic differentiation of the Devonian section at the north and its slight differentiation at the south and shows also the relatior ${ }_{\llcorner}$of the Onondaga fauna and formation to other formations or lithologic groups.

1 Mem. New York State Mus. No. 3, 1900, p. 9.

2 Maryland Geol. Survey, Allegany County, 1900, pp. 94-109. 
Table showing decreasing differentiation of formations in equivalent beds from northeast to southwest.

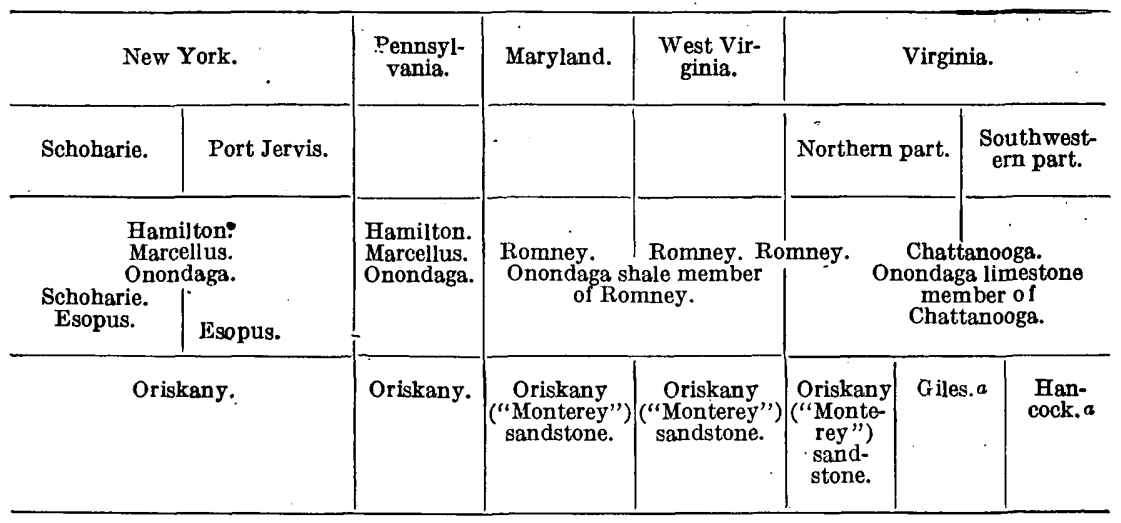

$a$ The intention here is not to correlate either the Giles formation or the Bancock limestone with the Oriskany sandstone, as their relative positions in the table suggest, but only to indicate their relation in the section to the Chattanooga shale and Onondaga limestone member.

The formational nomenclature which has been used in State and Federal reports relating to the Allegheny region illustrates the salient fact that the formations tend to converge toward a common lithologic type southward, but it is too much generalized and falls considerably short of representing all the facts with respect to subdivisions that can and should be discriminated. This nomenclature notably fails to recognize the important formation and fauna which constitute the subject of this paper. This formation, which will be called the Onondaga shale member of the Romney over most of the southern region, comprises in Pennsylvania a series of dark limestones and interbedded shales which lie between the Oriskany sandstone below and the fissile black carbonaceous shales of the Marcellus above. These stratigraphic boundaries are constant from the New Jersey line to and beyond James River in Virginia. The drab or dark shale is generally the predominant element of these strata in Pennsylvania, but in certain areas the limestones are the more prominent of the two, and some of these are pure enough to be burned for lime. Generally, however, the limestone bands carry a large percentage of argillaceous matter. After prolonged leaching these impure limestones acquire an appearance which affords but little suggestion of their original calcareous nature. Southward from Pennsylvania the calcareous element becomes less prominent until southwestern Virginia is reached; here over a small area we find a nearly pure limestone. The presence of limestones in the beds holding the Onondaga fauna, however, is not the only physical characteristic which distinguishes them from the fissile black shales above.

Another important distinguishing lithologic feature appears to have been overlooked. In Maryland, West Virginia, and Virginia, where 
the limestone is somewhat less prominent than in Pennsylvania, these lower shales, though variant in color, are noticeably lighter colored than those above the horizon at which calcareous beds are conspicuous. These upper strata are almost everywhere black, very fissile shales. The lower shales (Onondaga), on the other hand, comprise olive green, gray, buff, or cream colored beds, interbedded with a minor amount of black shale. These lower black shales differ fundamentally from the upper series in being generally though not invariably nonfissile and of the blocky type. The black shale in the lower terrane does not split or cleave in one direction more easily than in another. It shows in many sections much the same difference from a fissile shale that is shown by a piece of chalk or clay.

The fauna which characterizes these beds has up to the present time remained almost totally unknown, and this fact and the resulting erroneous assumption that these beds were a part of the Marcellus shale have probably caused the geologists who dealt with them south of the Pennsylvania-Maryland boundary to fail to recognize the Onondaga in their nomenclature. The geologists of the Pennsylvania State Survey, however, though unacquainted with the fauna of these beds, did not fail to recognize the fact that they constitute a lithologic unit distinct from either the beds above or those below. In Huntington County Ashburner ${ }^{1}$ as early as 1878, recognized the limestones and shales between the Oriskany and the Marcellus shale as a distinct formation and correlated it with the "Upper Helderberg" (Onondaga) of New York. In two counties in Pennsylvania I. C. White ${ }^{2}$ used a local name for these beds, calling them the Selinsgrove lower limestone and shale. Claypole, ${ }^{3}$ who supposed the strata under consideration to be characterized by a Marcellus fauna, divided his "Marcellus" formation into what may be considered three separate members, which he called Marcellus black shale, Marcellus limestone, and Marcellus lime shales.

These observations will suffice to show that though the Pennsylvania geologists were not familiar with the Onondaga fauna, they recognized the stratigraphic distinctness of the beds holding that fauna, and correctly correlated, at least one of them, on stratigraphic grounds alone, with the Onondaga of New York. The geologists working south of Pennsylvania have not entirely failed to recognize the distinctive lithologic features of these strata, although heretofore these beds have found no place in the formational nomenclature of the region. The geologic descriptions of the lower portion of the Romney shale in Maryland show the presence of limestones at a horizon corresponding to that of the lime shale which the Pennsylvania

1 Second Geol. Survey Pennsylvania, Rept. F, 1878, p. 223.

Idem, Rept. T3, 1885, p. 114.

8 Idem, Rept. F2, 1885, p. 62. 
geologists have all recognized at the base of the Marcellus. 'From Prosser ${ }^{1}$ I quote the following regarding the Maryland section:

About 150 feet from the bottom of the formation there are several bluish-gray fossil. iferous limestone bands. These are apparently never absent, although in the wellexposed Williams Road section none of them can be seen.. This is perhaps due to the effect of weathering, as certain evidence indicates their probable presence. These bands are individually rarely 3 feet, usually less than 1 foot, thick, but the total thickness in the best-exposed sections is more than 20 feet.

The above statement tallies with the testimony of the Pennsylvania geologists concerning the conditions at this horizon in Pennsylvania, as indicating a limestone and shale formation near the base of the Romney shale in Maryland. I would add to it the statement that the shales in this lower 100 to 150 feet in Maryland are generally of much lighter color than those of the Marcellus, in many places drab or olive. Those that are black are usually of the blocky type, without cleavage, and thus present marked contrast to the fissile Marcellus shale higher up.

In West Virginia and Virginia the distinctive lithologic features of these strata were partly recognized by the geologists who wrote the Piedmont and Franklin folios, although they did not, like the Pennsylvania geologists, treat these beds as separate members or formations. Darton and Taff ${ }^{2}$ describe these beds in the Piedmont area as follows: "The formation [Romney] includes occasional thin beds of fossilliferous limestone not far from its base."

A very similar description is given by Darton ${ }^{3}$ for the same beds in the adjacent area to the south.

Like Prosser's notes on the limestones in the lower Romney of Maryland, these observations on the limestone bands in the lower Romney of Virginia and West Virginia need to be supplemented by a statement of the lithologic characters of the shales associated with these limestone bands, which distinguish them from the shales of the Marcellus portion of the Romney.

Darton ${ }^{4}$ evidently recognized the same beds still farther south, in the Staunton quadrangle, for he states that "The formation includes occasional calcareous streaks not far from its base." $\mathrm{He}$ entirely omits to mention, however, other distinguishing lithologic features of this part of the Romney which I have fully shown in my section at Bells Valley, Va. (See pp. 43-45.)

The quotations given above indicate that the geologists who have written on the Romney shale recognized at least some of the distinctive lithologic characters of the beds holding the Onondaga fauna. In this connection it is necessary to consider briefly the definition

i Miaryland Geol. Survey, Allegany County, 1900, p. 105.

2 Piedmont folio (No. 28), Geol. Atlas U. S., U. S. Geol. Survey, 1896, p. 3.

${ }^{3}$ Franklin folio (No. 32), Geol. Atlas U. S., U. S. Geol. Survey, 1896, p. 3.

- Staunton folio (No. 14), Geol: Atlas U. S., U. S. Geol. Survey, 1894, p. 2. 
and lithologic features of the Romney shale and its relations to the Onondaga. The type locality of the Romney shale is Romney, W. Va. The name was proposed by Darton ${ }^{1}$ for a set of beds composed mainly of shales lying between the "Monterey" (Oriskany) sandstone below and the Jennings formation above. ${ }^{2}$ The Jennings has since been shown to carry the Portage and Chemung faunas. As thus defined, the Romney shale includes the beds holding the Onondaga fauna as well as the stratigraphic and faunal equivalents of the Marcellus shale and the Hamilton formation. Prosser ${ }^{3}$ has shown that the Romney includes the equivalents of the Hamilton and Marcellus formations of the New York section. It will be shown in this paper that it includes alse the equivalent of the Onondaga limestone.

The beds included in the Romney in Maryland and Virginia, both north and south of the type locality; are largely shales, forming valleys in which the limits of the different members can not be very readily observed. In the middle and southern Virginia region there is no such well-marked transition from the fissile black shale to the Hamilton above as can be easily recognized farther north, and it becomes most difficult to fix the precise limits of the beds which are to be correlated with the Marcellus and the Hamilton of Pennsylvania and New York. In much of this region, therefore, Romney shale becomes a useful term. It is a broader term than any of the formation names used in the New York section, for it includes the Onondaga, Marcellus, and Hamilton faunas. Hence, it is to be considered for the Virginia and Maryland region the approximate equivalent of the Ulsterian of Clarke ${ }^{4}$ and the Erian of Schuchert. ${ }^{5}$ In the more easterly sections, and toward the north, where the earlier named and more narrowly limited New York formations represented in the Romney can be discriminated on both faunal and lithologic evidence, these smaller units should be used.

As the eastern shore line of the Devonian sea is approached near the Potomac, sandstones are found to become a prominent element at the Hamilton horizon of the Romney, as they do in eastern Pennsylvania: This sandstone element is well developed in the Hedgesville section in West Virginia. Farther west and south both the faunal and the lithologic differences between the upper and lower portions of the Romney are less marked, as already pointed out.

1 Darton, N. H., Notes on the stratigraphy of a portion of central Appalachian Virginia: Am. Geologist, vol. 10, 1892, pp. 10-18.

2 In the original definition of the Romney shale Darton (idem, pp. 17-18) states that the formation contains "Cornilerous" species, but as none of the species cited are characteristic of the "Corniferous" this statement probably resulted from s, typographic error.

8 Prosser, C. S., Jour. Geology. vol. 12,.1004, pp. 361-372.

4 Mem. New York State Mus. No. 3, 1900, p. 9.

b Bull. Geol. Soc. America, vol. 20, 1910, p. 541. $20495^{\circ}-$ Bull. 508-12-2 
Where the lithologic differentiation is least prominent, however, the three types of faunas found in the Romney shale are still limited to the same relative parts of the section as farther north. The lowest of these faunas is confined to a sedimentary, series which includes, mainly, alternating drab or olive-green and black clay shales, with a few thin bands of impure limestone. Upon these lies a series of generally fissile black shales, with comparatively few drab or lightcolored shales. The uppermost division includes drab or sandy shales and sandstones carrying the Hamilton fauna. The lowest of these divisions, the Onondaga, is more persistent in its lithologic characters than the other two divisions of the Romney. Even where these two upper divisions have become nęarly indistinguishable by either their lithology or their faunas, the drab or dark shales with limestone bands and their distinctive Onondaga faunas may still be easily recognized. As the term Romney shale is useful to designate collectively these three recognizable divisions in parts of Maryland, West Virginia, and Virginia, it appears expedient to treat the Onondaga shale in that region as a member of the Romney shale.

In Virginia the limestone of the Onondaga becomes less and less prominent toward the southwest, almost disappearing in the James River region but reappearing in southwestern Virginia. South of James River the calcareous beds below the Marcellus, though more attenuated, can still be distinguished in good sections. In this southwestern region four quadrangles have been mapped by $M$. R. Campbell and a number of sections have been described by Williams and Kindle, but it appears that these geologists overlooked the Onondaga in this region, for they make no specific reference to it in their published work. ${ }^{1}$ It is present, however, over at least a portion of this southwestern area. At Big Stone Gap the Onondaga fauna occurs in a cherty limestone, 8 feet thick, which separates the black shale of the Chattanooga formation from the Hancock limestone, and is included in the Chattanooga as mapped. This limestone does not differ in physical character from typical exposures of the Onondaga limestone in New York State, but, being too thin to discriminate on maps and having been previously included in the Chattanooga shale as there defined, it will be treated as a member of the Chattanooga.

Summarizing the evidence which has been presented relative to the treatment of the beds holding the Onondaga fauna as a lithologic unit, I may say that I have shown, from the evidence of geologists, who know little or nothing about the faunas involved, that the Devonian section of the Allegheny region includes a set of calcareous shales which occupy a definite and uniform stratigraphic position from the New Jersey-Pennsylvania line to James River in Virginia. Within

1 Folios 12, 26, and 59, Geol. Atlas U. S.; Bull. U. S. Geol. Survey No. 242 
BULLETIN 508 PLATE I
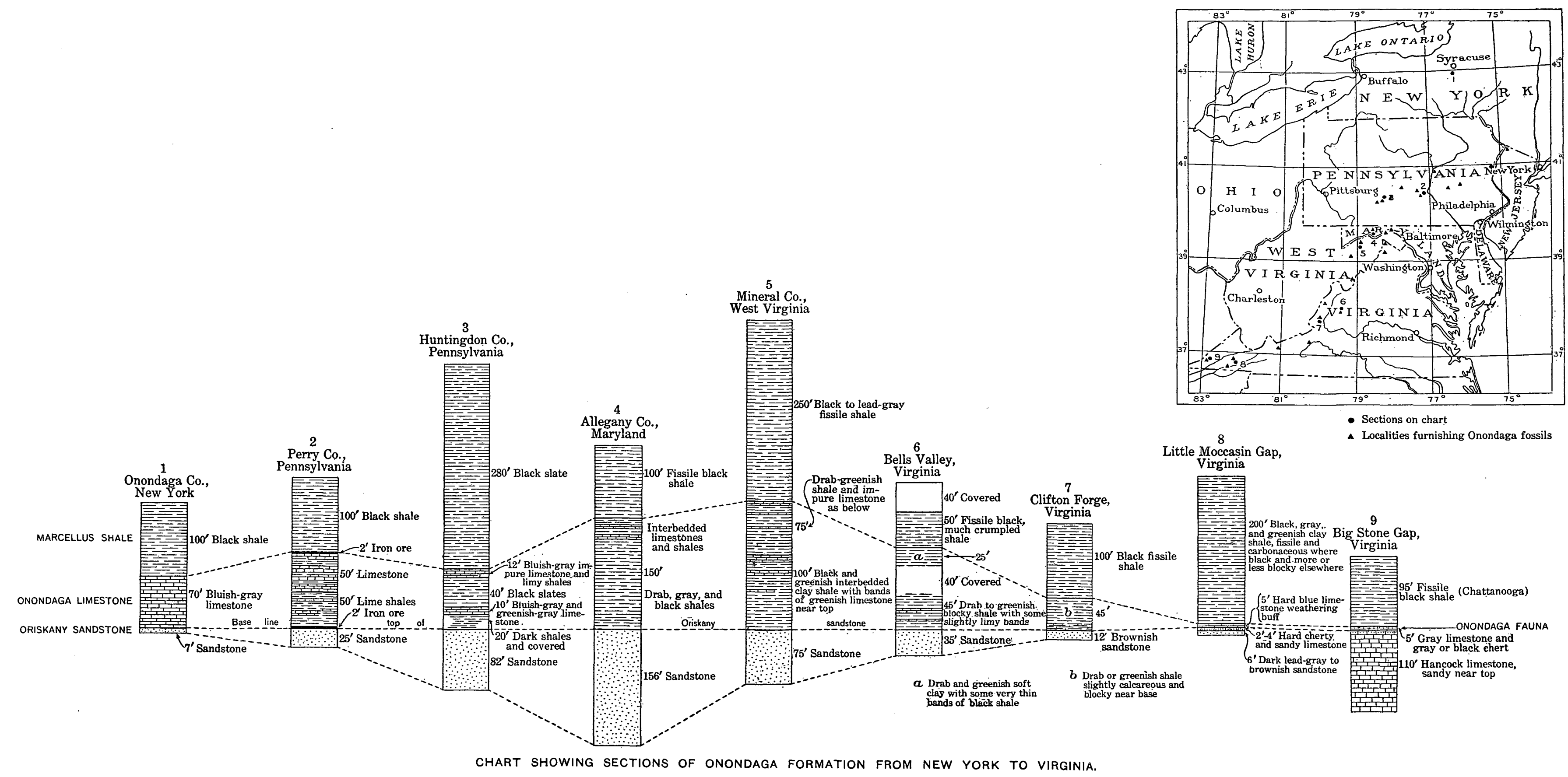

CHART SHOWING SECTIONS OF ONONDAGA FORMATION FROM NEW YORK TO VIRGINIA. 
this geographic district they lie above the Oriskany sandstone and below the fissile black shale, which, farther north, is generally called Marcellus, and which represents a part of the Romneyosouth of Potomac River. The same beds continue nearly to the Tennessee line, but become much thinner. They lie below and grade into black shales, like those found farther north, except in the vicinity of Big Stone Gap, where the change to the overlying black shale is abrupt, but in this southwestern region they generally rest on rocks that do not appear to be of Oriskany age. These shales which lie at the base of the Devonian shale series differ from the fissile black shales immediately above them not only in being somewhat calcareous but in being uniformly lighter in color, locally in part cream colored, and in being in many places nonfissile.

In the preceding discussion I have sought to show chiefly the lithologic and stratigraphic grounds for treating the beds under discussion as a distinct subdivision. Lest it might appear that the proposed discrimination of these beds as a distinct unit is based on their faunal rather than their lithologic distinctness, I have introduced into this general discussion of the stratigraphy the testimony of other geologists whose judgment in this respect was certainly not biased by a knowledge of the fauna. "The strength and the relations of this evidence can best be shown by assembling a few representative sections, which, for the reason just stated, are drawn as far as possible from papers already published. The accompanying chart of representative sections (Pl. I) shows that the stratigraphic relations of these beds are uniform from Pennsylvania to the middle portion of Virginia. The Allegheny sections are placed beside a section showing the Onondaga limestone and adjacent formations as they are developed in the type region of the Onondaga in New York State. The similarity of the stratigraphic position of the formation in central New York and in much of the Allegheny region is obvious.

The sections on the chart are based on published and unpublished data obtained from the sources indicated below:

1. Onondaga County, N. Y. After Clarke, J. M., and Luther, D. D., Bull. New York State Mus. No. 82, 1905.

2. Perry County, Pa. After Claypole, E. W., Second Geol. Survey Pennsylvania, Rept. F2, 1885.

3. Huntingdon, Pa. After White, I. C., and Ashburner, C. A., Second Geol. Survey Pennsylvania, Rept. F, 1878; Rept. T3, 1885.

4. Maryland. Generalized after Prosser, C. S., Maryland Geol. Survey, Allegany County, 1900.

5. West Virginia. Kindle.

6. Bells Valley, Va. Kindle.

7. Clifton Forge, Va. Kindle.

8. Little Moccasin Gap, Va. Kindle.

9. Big Stone Gap, Va. Kindle. 


\section{DETAILED STRATIGRAPHY.}

\section{NEW YORK.}

A brief account of the stratigraphy of the Onondaga and closely associated formations in southeastern New York is introduced here for convenience of comparison and correlation with the Allegheny sections.

In the Helderberg Mountains of eastern New York the Onondaga limestone exhibits its typical development, and in no other region can its relations to the adjacent formations be studied to greater advantage. These formations are exposed in the face of the bold and imposing cliffs of the Helderberg escarpment, which rises abruptly more than 1,000 feet above the broad valley of the Hudson. This is classic ground to American geologists, having served as the geologic nursery of such men as Eaton, Mather, Emmons, Conrad, Hall, and Agassiz. The writings of these authors, as well as many later papers, have contributed to the elucidation of the geology of the Helderberg Mountains. This area, therefore, serves well as a starting point for stratigraphic studies in the much less well-known region farther south. As a standard for comparison I may introduce here a typical section of the Devonian seen at and south of Countryman Hill, near the north end of the Helderberg Mountains. The greater part of this section, except the Marcellus and Hamilton formations, is exposed along the highway immediately west of the village of New Salem. The thicknesses given for the Hamilton and Marcellus are based on Prosser's Clarksville section, ${ }^{1}$ which was taken a few miles south of the New Salem section.

Section in the Helderberg Mountains, southwest of Albany.

Hamilton: Brownish arenaceous shales and sandstones with black arenaceous shales in lower 200 feet

Feet. 490

Marcellus: Black argillaceous shales with dark, slightly calcareous sandstones. This formation shows gradual transition to the arenaceous shales of the Hamilton.

Onondaga: Massive light-gray limestone with considerable chert locally. Brachiopods and corals common but not abundant...

Schoharie grit: An impure dark-gray limestone which weathers to a buff porous sand rock.........................

Esopus shale: Blackish or dark-gray arenaceous shales which contain few or no fossils except Spirophiton cauda-galli. ..........

Oriskany: Coarse sandstone varying from dark quartzitic rock to soft brownish sandstone. Fossils abundant...............

Becraft limestone: Gray coarse-grained heavy-bedded limestone with numerous fossils..............................

New Scotland limestone: Drab calcareous shale with some intercalated beds of blue limestone. Fossils abundant............

1 Prosser, C. S., and Rowe, R. B., Stratigraphic geology of the eastern Helderbergs: Fifty-first Ann. Rept. New York State Mus., vol. 2, 1899, p. 346. 
.

Manlius limestone: Dark-blue thin-bedded fine-grained limestone.

Tentaculites and ostracodes abundant.

The descriptions of the above section are taken from my notes, but the thicknesses are quoted from the carefully measured and more detailed sections published by Prosser and Rowe. ${ }^{1}$ The total thickness is indicated for each of the formations represented in the section except for the Hamilton, only the lower portion of which is present at the eastern margin of the Helderberg Mountains. The thickness given for the Hamilton represents only the portion exposed near Clarksville, ${ }^{2}$ a few miles south of Countryman Hill, which is perhaps little more than one-third of its entire thickness. About 4 miles west of New Salem nearly the entire Hamilton section is exposed in the high hill just south of the village of East Berne. Here it is mainly a sandstone formation, the interbedded shales representing a minor element.

Clarksville is the best-known locality for Onondaga fossils in the Helderberg region. The following is a list of the Onondaga fauna from this locality recorded by Prosser and Rowe. ${ }^{3}$

Meristella unisulcata (Con.) H.... Leptæna rhomboidalis (Wilck.) $\mathrm{H}$. $\&$ C.

Atrypa reticularis (Lin.) Dal.....

A. spinosa $\mathrm{H} . . . . . \ldots \ldots \ldots$.........

Pentamerella arata (Con.) H......

Stropheodonta concava H.......

S. textilis $\mathrm{H}$

Spirifer duodenaria H............

S. macra H. (?)................

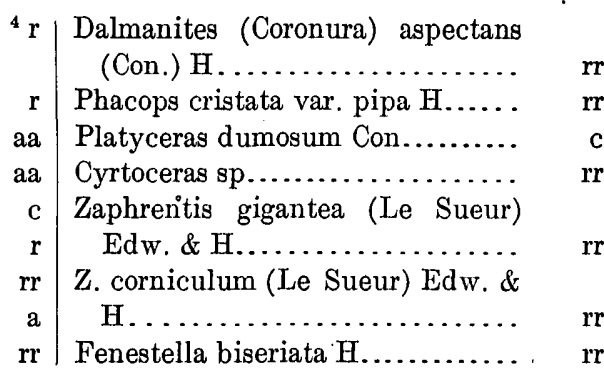

From the Countryman Hill section southwest of Albany the line of outcrop of these formations extends southward parallel to the Hudson to Kingston, thence southwestward to the New Jersey-! : Pennsylvania boundary at Tristates, N. J.

In the Schoharie Valley, which is the type region of the Schoharie grit, that formation is estimated to be 5 or 6 feet thick, and the Esopus shale below it is from 80 to 90 feet thick. ${ }^{5}$ In the northeastern part of the Helderberg region the Schoharie grit and Esopus shale are readily distinguishable, the former being a gray, highly siliceous limestone which weathers to a porous sandstone that is generally fossiliferous, and the latter a drab to blackish siliceous shale without

1 Op. cit., pp. $335,338$.

2 Idem, p. 346.

3 Idem, pp. 352, 353.

4 The following abbreviations are used in the fossil lists in this bulletin: a, abundant; aa, very abundant c, common; $r$, rare; rr, very rare.

6 Grabau, A. W., Guide to the geology and paleontology of the Schoharie Valley in eastern New York Bull. New York State Mus. No. 92, 1906, pp. 170, 180. 
lime, nearly or quite barren of fossils. Farther south, however, the distinctions between these two formations become vague and finally disappear. At Hudson, where these formations comprise, according . to Grabau, ${ }^{1}$ about 300 feet of "dark chocolate-colored gritty shales," the distinctions between the two are not very well marked and " 150 to 200 feet of strata lithically similar to the Esopus but more cleaved are referred to the Schoharie formation, since some of the characterteristic fossils have been found in them." ${ }^{2}$ Still farther south no line of division can be drawn between the two. At Kingston Van Ingen ${ }^{3}$ has applied the name Esopus grit to the entire mass of olivebrown fine-grained argillaceous grit that occupies the interval between the Onondaga limestone and the Oriskany sandstone. These grit beds have here a thickness of about 300 feet.

In the vicinity of Kingston and Rondout and southward into New Jersey the Esopus grit contains few fossils except Anoplotheca acutiplicata, which can be found at most localities where the formation occurs.

The very gradual transition of the Esopus shale into the Onondaga limestone at Kingston clearly indicates that the Schoharie is not represented by an unconformity in this region, but has become an integral part of the Esopus. With reference to this transition Van Ingen ${ }^{4}$ states that "the upper part of the Esopus grit merges into the lower portion of the Onondaga by such gradual changes that no line of demarcation can be drawn."

From the preceding summary of the more important facts concerning the relations of the Onondaga and subjacent formations in southeastern New York it appears that there is no stratigraphic break between either the Onondaga and Esopus or the Esopus and Schoharie. It is probable that sedimentation continued without interruption from the Oriskany into the Onondaga in at least a part of this area.

\section{NEW JERSEY.}

The grit series at Tristates, where it passes across the New YorkNew Jersey boundary, has been treated as a single formation by Weller, ${ }^{5}$ who applied to it the name Esopus shale. Anoplotheca acutiplicata occurs rather commonly in the formation near the schoolhouse and east of the river road $1 \frac{1}{2}$ miles below Tristates. .

At Tristates the Esopus is a very hard drab-colored siliceous shale, with slaty cleavage at right angles to the bedding. It weathers into

1 Grabau, A. W., Stratigraphy of Becraft Mountain, Columbia County, N. Y.: Bull. New York State Mus. No. 69, 1903, p. 1069.

2 Grabau, A. W., Bull. New York State Mus. No. 92, 1906, p. 181.

3 Van Ingen, Gilbert, Disturbed fossiliferous rocks in the vicinity of Rondout, N. Y.: Bull. New York State Mus. No. 69, 1903, p. 1204.

4 Idem, p. 1205.

5 Weller, Stuart, A report on the Paleozoic paleontology of New Jersey: Geol. Survey New Jersey, Paleontology, vol. 3, 1902, p. 102. 
fine splintery fragments. The very uniform character of the material composing it gives no indication of bedding planes where fossils are absent.

The Onondaga limestone, which lies immediately above the Esopus shale, forms a low, narrow ridge separating Delaware and Navesink rivers just above their confluence. The monument marking the junction of the States of New York, New Jersey, and Pennsylvania is located on the point of this ridge. The Onondaga limestone forms the east bank of Delaware River below the Navesink for several miles and outcrops at intervals below Tristates. In this region it is a hard, bluish-gray, slightly impure limestone containing an abundance of chert. At Tristates the Onondaga appears to contain a slightly greater percentage of argillaceous matter than it does farther north, but the difference is slight and the lithologic facies differs but little from that seen in the Countryman Hill section. The Marcellus shale at the top of the Onondaga shows no indication of a lithologic modification such as that which has reduced the Schoharie grit at the base of the Onondaga to an indistinguishable part of the Esopus north of the New Jersey line. The Marcellus continues on into Pennsylvania with the same fissile black shale facies that is seen in the Countryman Hill section.

Fossils are not abundant in the Onondaga limestone near Tristates and those that are present are difficult to extract from the tough cherty limestone. At the mouth of Neversink River, where the Onondaga limestone is well exposed, only two species were found, both characteristic Onondaga forms, namely, Odontocephalus ægeria or $O$. selenurus and Phacops cristata var. pipa. The faunule recorded by Weller ${ }^{1}$ from a locality a few miles below Tristates is probably a representative Onondaga faunule for this region. It is as follows:

Zaphrentis sp. undet.

Lingula sp. undet.

Leptæna rhomboidalis (Wilck.).

Schuchertella pandora (Bill.).

Rhipidomella vanuxemi (Hall).
Atrypa reticularis (Linn.).

Spirifer sp. cf. S. varicosus Hall.

Anoplotheca concava (Hall).

Platyceras sp. undet.

Anoplotheca acutiplicata is recorded by Weller from two localities in this region and appears to be a common species of the Onondaga in New Jersey as it is in Pennsylvania.

\section{PENNSYIVANIA.}

General conditions.-Near the mouth of Flat Brook Creek the Onondaga limestone crosses to the Pennsylvania side of Delaware River. Geologists ${ }^{2}$ have agreed in recognizing the presence of the

1 Weller, Stuart, op. cit., p. 104.

Lesley, J. P., Summary Rept. Geol. Survey Pennsylvania, vol. 2, 1892, pp. 170-172. White, I. C., Geol. Survey Pennsylvania, vol. G6, 1882, p. 120. Prosser, C. S., The Devonian system of eastern Pennsylvania and New York: Bull. U. S. Geol. Survey No. 120, 1894, pp. 3, 4. 
Onondaga and Esopus ${ }^{1}$ formations west of Delaware River in Pennsylvania as far as Stroudsburg, but their presence beyond this point to the southwest has generally been denied, as noted in preceding pages.

Throughout the 150 miles of outcrop of the Onondaga and Esopus formations from Albany, N. Y., to Stroudsburg, Pa., the lithologic and stratigraphic evidence of the identity of these two formations in the innumerable sections which may be studied is so clear and evident as to require no special reference to the paleontologic evidence. In the region southwest of Stroudsburg, however, consideration of both classes of evidence is indispensable to sound conclusions. In nearly all the sections some thin beds of limestone, interbedded with beds of drab gray or black shale, lie above the Oriskany sandstone. The limestones, however, contain characteristic Onondaga fossils, indicating that they were contemporaneous with the nearly pure Onondaga limestone found farther north. Their interbedding with the dark shales clearly shows that the black-shale sedimentation which overspread the entire area of the Onondaga limestone in New York at the end of Onondaga time began in the Allegheny region in Onondaga time.

Stroudsburg section.-At East Stroudsburg, $\mathrm{Pa}$., a few miles west of Delaware River, the Onondaga is still distinctly a limestone formation and exhibits the flint lenses and nodules so characteristic of the formation in New York. This limestone and nearly the entire thickness of the Esopus shale underlying it may be seen in the cut on the Delaware, Lackawanna \& Western Railroad one-half mile south of the Stroudsburg station and in the pasture just north of the cut. Onondaga fossils are abundant at the latter locality (station $22 a$, Stroudsburg, $\mathrm{Pa}$.) near the spring, where the faunule listed below was collected:

Zaphrentis simplex............. c| Chonetes mucronatus............ c

Cystiphyllum sp............... r r Cyrtina hamiltonensis........... r

Fenestella sp................. c c Leptæna rhomboidalis........... r

Cladopora sp................... c Pentagonia unisulcata $. . . \ldots \ldots \ldots . . . .$.

Chonetes sp................... c Tentaculites bellulus............. c

The Oriskany and Helderberg formations are not exposed at the Stroudsburg cut, but are well exposed, together with a portion of the Esopus, along the Delaware, Lackawanna \& Western Railroad near the paper mill 2 miles east of Stroudsburg. Exposures of the Onondaga limestone in the vicinity of the crossroads one-third mile north of the paper mill give a nearly complete section from near the base of the Helderberg limestone to the top of the Onondaga limestone. Below the paper mill the entire thickness of the Oriskany sandstone

1 Prosser, Lesley, and White use the older names "Corniferous" and "Cauda-galli" grit instead of Onondaga and Esopus. 
is seen in the railroad cut, where it stands vertical, forming the backbone of the ridge southeast of Stroudsburg, through which Broadheads Creek breaks: The Oriskany here is only about 50 feet thick. It is followed by dark ash-gray, tough, hard, siliceous shale, about 250 feet thick, which in some beds is slightly calcareous, and which has pronounced slaty cleavage nearly at right angles to the bedding. In lithologic character and stratigraphic position these siliceous beds correspond to the Esopus shale and appear to represent the extension of that formation into northeastern Pennsylvania. The Onondaga limestone, lying above the Esopus, has a thickness of nearly 200 feet. Its appearance indicates that it contains a considerable proportion of argillaceous material. A sample of the limestone from Stroudsburg has been reported ${ }^{1}$ by Lesley to show 19.9 per cent of "insoluble residue." . So large a percentage of noncalcareous material indicates that contemporaneous beds composed mainly of argillaceous material might be found at no great distance. Some of the Onondaga sections in western New York which show thin bands of shale separating limestone strata of much greater thickness suggest a similar probability. Eight separate thin bands of shale occur within a thickness of 25 feet of the Onondaga limestone at Williamsville, N. Y. As a formation which is chiefly limestone the Onondaga ceases to exist a short distance west of Stroudsburg and is represented by beds which in many places are more argillaceous than calcareous. That the impure limestone seen at Stroudsburg passes into a shale containing subordinate beds of limestone in the region west and southwest of Stroudsburg will be shown in succeeding pages.

West of Stroudsburg the Onondaga limestone outcrops typically about 2 miles west of town, just west of Michaels Creek on the Saylorsburg and Stroudsburg road. Beyond this point, however, lithologically typical exposures cease.

Saylorsburg section.-The area in which the Onondaga limestone should outcrop between Stroudsburg and Saylorsburg is covered by a considerable mantle of drift, but the nearly complete absence of outcrops of the formation in this region indicates that shale probably predominates 'over the limestone constituent of the formation southwest of Stroudsburg. The first satisfactory exposures of any part of the Devonian section which one encounters in going westward from Stroudsburg occur in the railway cut at Saylorsburg, about 15 miles west of Stroudsburg. The beds there exposed represent only the Oriskany and are indicated in the following section:

\section{Section at Saylorsburg, $P a$.}

b. Light buffish-brown coarse to medium coarse sandstone, with Oriskany fossils...................................

$a$. Very fine textured cream-colored or buffish tough shale........ 
Neither the beds above nor those below the Oriskany are exposed at Saylorsburg, but 2 miles west of that village the Helderberg limestone has been quarried extensively and is well exposed. Immediately north of these quarries the typical upper Oriskarry sandstone and its fossils are seen, and in prospect pits between the Helderberg limestone and the typical Oriskany sandstone the white clay representing the beds $a$ of the above section (lower Oriskany) is found. This white shale or clay as it occurs in the ridge immediately east of Saylorsburg is extensively utilized in making a milk-white enamel and brick. So far as known; this phase of the lower Oriskany is without parallel in the Allegheny region, these lower beds, as commonly developed in Pennsylvania, being dark-gray, brownish, or black, more or less calcareous, fine-grained sandstones. Attention is directed to this unusual facies of the lower' Oriskany because it occurs in precisely the same area in which a somewhat similar change occurs in the Onondaga formation and because in each area the change consists of a reduction in the calcareous content of the rocks. It is probable that similar physical conditions operated to produce this transformation in the two formations in this area.

White ${ }^{1}$ states that the Onondaga is "apparently thin and very arenaceous" in this region. Its failure to outcrop over considerable areas southwest of Stroudsburg indicates clearly its comparatively soft and argillaceous or arenaceous character in that region.

Lehigh River sections.-The Lehigh River section, which is about 5 miles west of Saylorsburg, indicates that the beds representing the Onondaga formation between Stroudsburg and Lehigh River are not only thinner and much less calcareous than the Onondaga to the northeast, but that they are likewise much less calcareous than the same formation to the southwest, in central Pennsylvania.

As with the white lower Oriskany shale and clay at Saylorsburg the unique physical characteristics of the Onondaga formation at Lehigh River has led to its exploitation for commercial purposes, one of the beds which I-refer to this formation having been worked for more than 100 years as a paint ore.

So far as observed the beds representing the Onondaga formation do not outcrop on Lehigh River and can be seen only in the drifts of the paint mines but nearly all the rest of the Devonian section is well exposed along the river above Hazard. The following section quoted from Lesley ${ }^{2}$ shows the general relation of the beds under consideration in the Lehigh River section:

1 Geol. Survey Pennsylvania, vol. G6, 1882, p. 119.

2 Lesley, J. P., Summary Rept. Geol. Survey Pennsylvania, vol. 2, 1892, p. 1175; Geol. Hand Atlas of Pennsylvania, 1885, p. 33. 
Section on Lehigh River above Hazard, $P a$.
f. Gray shales and sandstones (Hamilton) . . . . . . . . . . . . $\quad 760$
e. Fissile black shale (Marcellus) ...................... $\quad 800$
d. Cement layers................................... $\quad 30$
c. Shale with iron pyrites............................ $1-2$
b. Drab-colored clay ............................... 3-8

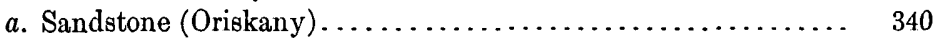

Lesley ${ }^{1}$ reports that a bed of 5 feet of limestone, which he considered of Onondaga age, lies at the base of the Marcellus shale in one of the paint tunnels near Lehigh River at Hazard, although he has not indicated it in the above section. Bed $c$ of the section furnishes the paint ore mined in the vicinity of Hazard and Bowman. The paint ore is carbonate of iron disseminated through a fine-textured shale in which nodules of iron pyrites also occur.

The "cement beds," $d$, above the ore, are shales sufficiently calcareous to be used for cement, thus approaching limestone rather closely in composition. Near Hazard the black shales above the cement beds of the paint mine contain Ambocolia umbonata, Leiorhynchus limitare, Strophalosia truncata, Bactrites aciculum, and Styliolina fissurella, indicating a Marcellus horizon.

The beds $b, c$, and $d$ of the above section are believed to represent the Onondaga formation. Owing to their depth and inaccessibility except in the paint mines no fossils were secured from them and their reference to the Onondaga formation is based on their stratigraphic position between beds containing a Marcellus fauna and the Oriskany sandstone. Their position in the section is identical with that of beds which, in other Pennsylvania and New York sections, are known to carry an Onondaga fauna. Above and below the horizon of the "paint and cement beds" the Devonian section corresponds closely with that of New York in both lithologic and faunal features.

Schuylkill River section.-In the Schuylkill River section, 25 miles southwest of Lehigh River, the fossils afford undeniable evidence of the presence of the Onondaga fauna. About 35 feet of dark bluishgray argillaceous limestone and interbedded calcareous shale outcrop in the wagon road on the south side of the river at Schuylkill Haven (station 27c). The following fauna occur in these beds:

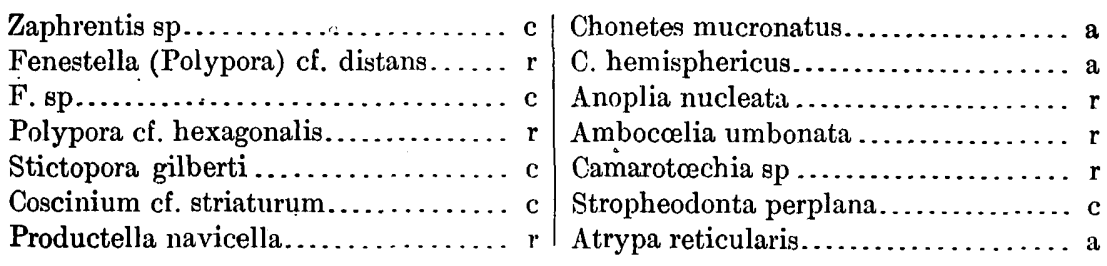

i Summary Rept. Geol. Survey Pennsylvania, vol. 2, 1892, p. 1175. 
Leptæna rhomboidalis

Schuchertella cf. perversa............. r

Pentagonia unisulcata.............. r

Spirifer acuminatus................ $r$

S. sp. cf. varicosus ............... c

Schizodus sp
Actinopteria sp.................. r

Platyceras sp.................. r $r$

Bellerophon leda................ r

Tentaculites cf. bellulus............ r

Phacops cristata................. $r$

The above association of species can be referred to no other horizon than that of the Onondaga formation, for, although characteristic Onondaga species, such as Spirifer acuminatus and Pentagonia unisulcata, have in a few places been recorded from a post-Onondaga horizon, others here present, such as Phacops cristata and Anoplia nucleata, though known at an earlier horizon, are unknown at any later one. The portion of the section immediately below the Onondaga is not exposed in this section, hence no data were obtained relative to the presence or absence of the Esopus.

The Oriskany sandstone is probably in few places more than 5 feet thick in the vicinity of Schuylkill River. No outcrops of it were observed, but its presence is shown by a narrow belt of coarse sandstone or conglomerate bowlders extending across the fields.

West of Schuylkill Haven, on the east side of Schuylkill River, near the Pennsylvania Railroad station, beds outcrop which seem to be the stratigraphic equivalents of the limestone with the Onondaga fauna. They comprise about 20 feet of blocky dark-bluish shales, weathering drab, with thin bands of hard dark-blue impure limestone containing trilobite fragments. A nearly complete section is exposed above these along the railroad up to and through the shales and sandstones of the Hamilton formation. In this section the Marcellus consists largely of clay shales, whose drab color is probably due in part to weathering. The lower part of these shales contain Leiorhynchus limitare and Styliolina fissurella.

Swatara Creek section.-The valley of Swatara Creek breaks across the Allegheny ridges 15 miles southwest of Schuylkill Haven, affording a good section across a portion of the Devonian rocks at Pine Grove. Alongs the wagon road about a mile south of Pine Grove the black Marcellus shale is exposed poorly below the Hamilton, which is here a massive, coarse-grained sandstone nearly 200 feet thick. The Onondaga is represented by no satisfactory outcrops, but loose pieces of black thin-bedded and very impure limestone are not uncommon at this horizon. These contain Anoplotheca acutiplicata, Chonetes mucronatus, etc.

Falling Spring section.-On the west side of Susquehanna River, in Perry County, the Onondaga may be seen at many localities at the base of the Marcellus shale. When found at drainage level or in the bed of a stream, it is a very hard, tough, argillaceous limestone, generally interbedded with dark or drab shales. If above drainage, the lime is often almost if not completely leached out, leaving a tough, 
blocky, shalelike rock. In its unaltered condition it is seen at Falling Spring on Shermandale Creek, as shown in the following section:

\section{Section at Falling Spring (station 20).}

c. Hard blue argillaceous limestone in layers 8 to 12 inches thick, interbedded with thinner layers of black shale........... 25

$b$. Drab, hard, gritty shale, closely mottled with gray wavy lines resembling worm trails........................... 40

a. Hard coarse gray to buff sandstone (Oriskany) $\ldots \ldots \ldots \ldots \ldots \ldots . \ldots \ldots$

In the limestone beds, $c$, the following fauna occurs:

Strophalosia truncata.............. a a Cranæna cf. romingeri............. r Chonetes sp..................... $\mathrm{r}$ Odontocephalus selenurus..........

No fossils were found in the 40 feet of drab mottled shale, $b$, immediately above the Oriskany, and in this respect it corresponds with the Esopus shale, much of which is barren. In physical features its resemblance to the Esopus of southeastern New York is marked. Like the Esopus shale, it occupies the interval between the Oriskany sandstone and the limestone beds containing an Onondaga fauna, thus suggesting its possible equivalence to the Esopus shale.

New Bloomfield sections.-Although Claypole failed to recognize the Onondaga fauna in Perry County, he described ${ }^{1}$ a section near New Bloomfield, in which he believed the Schoharie grit to be represented, basing his opinion on the discovery of Atrypa impressa, which he considered to represent the same type of the species seen in the Schoharie of New York. Although none of the sections studied by me seem to show conclusive evidence of the presence of the Schoharie grit in Pennsylvania, it may be represented by a portion of the shale of division $b$ in the Falling Spring section.

The most satisfactory exposure of the Onondaga which I have seen in Perry County occurs in the following section, ${ }^{2}$ at the southwest side of New Bloomfield, just above Clousers Dam. The Marcellus shale, which occupies the valley immediately south of the limestone outcrops, is not exposed in that vicinity.

Section at southwest side of New Bloomfield, above Clousers Dam (station 99).

$b$. Hard bluish-gray argillaceous limestone and interbedded dark: gray calcareous shale.......................... 56

a. Coarse crumbling sandstone (Oriskany) ................ 20

The beds of this section belong to a partly overturned fold, and show a northerly dip of $40^{\circ}$ instead of the southerly dip which as part of the south limb of a normal anticline they would exhibit. The limestone

1 On the equivalent of the Schoharie grit of New York in middle Pennsylvania: Proc. Am. Philos. Soc., vol. 20, 1883, pp. 534-536.

2. My attention was first đirected to this section by Mr. Luke Baker, of New Bloomfield, to whose zeal the Survey is indebted for a valuable collection of Onondaga fossils. 
and calcareous shale $(b)$ of the Onondaga outcrop for about 200 yards above the dam. A partial list of the fossils occurring here follows:

Zaphrentis cf. simplex.............. 'c Dalmanella lenticularis............. c

Orbiculoidea sp.................. $r$ Rhipidomella vanuxemi............ $\mathbf{r}$

Atrypa reticularis................ c Cyrtina hamiltonensis............ r

Ambocœlia umbonata............ r r Phacops cf. cristata ............. r

Anoplia nucleata ................ $\mathrm{r}$ Bollia ungula................. a

Imperfect exposures of leached beds of the argillaceous Onondaga limestone occur one-eighth mile southeast of New Bloomfield, at the Pulpit Rocks. The vertical beds of the Oriskany sandstone, which resist erosion more effectively than the adjacent formations, here form a hill crest of massive sandstone blocks. Immediately south of these (station $39 a$ ) the olive-gray blocky shale furnished the following species:

Leptostrophia perplana........... $\mathbf{r}$ i Styliolina fissurella.............. a

Stropheodonta cf. inequistriata....... $\mathbf{r}$ Phacops cristata var. pipa......... c

Rhipidomella vanuxemi............ a Acidaspis callicera............... c

Dalmanella lenticularis............. c. Odontocephalus sp............. r

Anoplea nucleata. .............. r $\mathbf{r}$ Bollia ungula .................. c

Nucleospira concinna.............. c Bythocypris favulosa............ c

Leptænisca australis n. sp........... c

Alinda section.-About 8 miles west of New Bloomfield and threefourths mile east of Alinda, opposite the Benjamin Zimmer farm, the Onondaga is well exposed in a roadside cutting. The beds include the Devonian section from near the top of the Onondaga nearly to the base of the Helderberg limestone.

Section three-fourths of a mile east of Alinda, Perry County, Pa.

a. Drab-gray clay shale, ostracodes abundant.............. 15

$b$. Hard blue-gray calcareous shale or very argillaceous limestone,

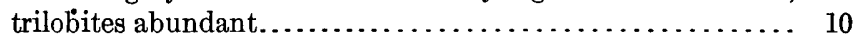

c. Drab shale with some limy bands.................. 15

d. Coarse conglomeratic sandstone (Oriskany) ............. 20

$e$. Soft buff sandstone, and covered.................... $80 \pm$

$f$. Drab shaly blue limestone, with interbedded chert at top.... $100 \pm$

Bed $b$ of this section has, as a result of the industry and enthusiasm of Mr. J. W. Shiveley, of Alinda, yielded some of the most complete specimens of trilobites found in the Onondaga (Pls. X-XI).

Iron-ore beds.- In many Perry County sections a band of iron ore 2 feet or less in thickness separates the Oriskany sandstone from the Onondaga shale, though it can seldom be seen except in old ore pits. One of the localities where it is present is $2 \frac{1}{4}$ miles southwest of New Bloomfield, on the Samuel Baker property, 180 yards south of the wagon road, where the old ore drift follows the top of the Oriskany, but neither the ore nor the shales immediately above it are now exposed. At the time when Claypole's survey of the county was in progress 
some of the ore pits were in operation, showing the thickness and relations of the two iron-ore beds in the Onondaga shale more clearly than they can be seen at present. Claypole ${ }^{1}$ gives the following generalized section of these beds:

Generalized section showing iron-ore beds.

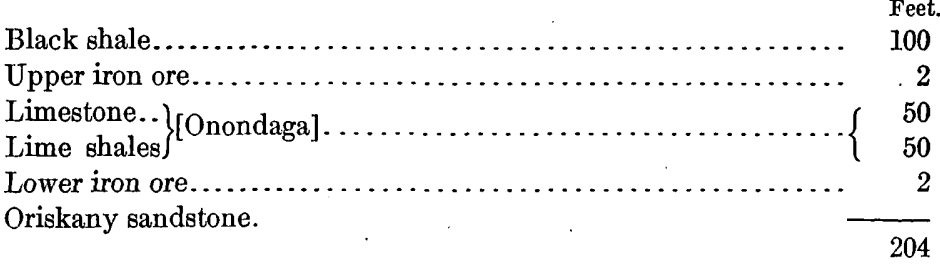

Selinsgrove section.-Near the forks of Susquehanna River, in central Pennsylvania, the Onondaga fauna occurs in dark bluish-gray argillaceous limestone, which is well exposed just below the Selinsgrove Junction bridge along the Northern Central Railroad. This bed, which is here about 70 feet thick, has been called the Selinsgrove lower limestone by White, ${ }^{2}$ who applied the name Selinsgrove shale to the light-gray shale below the limy beds. This shale, which seems to be barren, has a thickness of about 140 feet and appears to hold the same stratigraphic position as the Esopus. No complete list of the fauna occurring in the Selinsgrove limestone of White has been prepared. It includes, however, among others, Anoplotheca acutiplicata, Chonetes cf. hemisphericus, Ambocœlia umbonata, Orthoceras sp., Loxonema sp., Octonaria stigmata, and other ostracodes.

McVeytown section.-At McVeytown, 35 miles west of Susquehanna River, the Onondaga fauna is represented in the following section:

\section{Section at Mc Veytown (station SS).}

e. Hard dark-gray to black limestone, in 6 to 12 inch strata, which are somewhat argillaceous at the top.............. 15

d. Covered, mostly shale............................ 20

c. Greenish-gray shale, with three bands of limestone having an average thickness of about 6 inches. . . . . . . . . . . . 10

b. Covered .................................. $40 \pm$

a. Light-buff to white, fine-grained quartz sandstone (Oriskany). . $50 \pm$

Fossils were collected from beds $c$ and $e$ of the above section. The limestone bands, $c$ (station 33), afforded the following species:

Chonetes sp.

Ambocoelia cf. nana.............. r

A. umbonata.

Stropholosia cf. truncata.......... r

Rhipidomella vanuxemi........... c

Dalmanella lenticularis............ c

Nuculites modulatus n. sp.
Nucula cf. corbuliformis............ r Loxonema sp.................. $r$

Styliolina fissurella.............. a

Dalmanites $\mathrm{sp} . \ldots \ldots \ldots \ldots \ldots \ldots \ldots r$

Bollia ungula..................

Ulrichia conradi............. r 
fauna:

In the limestone, $e$, at the top of the section occurs the following

Orbiculoidea lodiensis var. media..... r

Chonetes mucronatus............ r

Stropholosia truncata............ c

Martinia? sp..................... c

Odontocephalus selenurus.......... c

Upper Reese section.-The most westerly outcrops of the Middle and Lower Devonian rocks in Pennsylvania are found in the belts of inclined strata which dip under the Allegheny front and trend southward or southwestward to the Maryland line from the vicinity of Hollidaysburg. Sections in this region which expose the Oriskany sandstone and the beds immediately following are very similar to those previously described from the more easterly sections. The following is a representative section taken at side of the highway a few miles east of Hollidaysburg and $1 \frac{1}{2}$ miles south of Upper Reese station.

Section $1 \frac{1}{2}$ miles south of Upper Reese station (station 31).
$a$. Fissile black clay shale (Marcellus)
Ft. in.
b. Covered.
$30+$
. Greenish thinly laminated shale................. 60
$d$. Gray, nearly pure limestone..................... 1

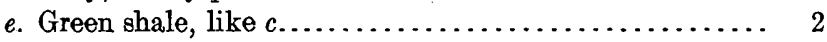
$f$. Dark, rather earthy limestone....................
g. Green shale, like $c$, with very calcareous bands....... 18
$h$. Dark-gray limestone......................... 1
$i$. Greenish clay shale....................... 2
j1. Fissile black clay shale, containing Chonetes mucronatus and Stropholosia.......................... 22
j2. Fissile black shale, as above, with Orbiculoidea and Conu- - laria .................................... 10
k. Covered, but shale weathering to light-colored clay. ... 10
l. Red iron-ore band........................... $6 \pm$
$m$. Buff crumbling sandstone (Oriskany)............. 20+

The faunal details are shown by the following lists of species collected from the several divisions of the section. Fossils are present in the lower beds, but the black shales $j 1$ and $j 2$ are the lowest beds that show an abundance of individuals, though few species.

Station $31, j 1$ :

Stropholosia truncata. . . . . . . . . . . . . . . . . . . . . . a

Chonetes cf. mucronatus........................... a

Station $31, j 2$ :

Orbiculoidea lodiensis var. media.................... a

Bactrites cf. aciculum. . . . . . . . . . . . . . . .

Conularia sp. . . . . . . . . . . . . . . . . . . . .

In the greenish clay shales, $i$, next above, the following species occur:

Styliolina fissurella. 
The beds that are richest in fossils in this, as in most other sections showing this fauna, are the calcareous beds. These are typically developed in $g$ of the section, which furnished the following species:

\begin{tabular}{|c|c|}
\hline $\begin{array}{l}\text { mbocœelia umbonata .......... } \\
\text { noplia nucleata ............ }\end{array}$ & $\begin{array}{l}\text { Dalmanites (Cryphæus) cf. boothi var. } \\
\text { calliteles. . } \ldots \ldots \ldots \ldots \ldots \ldots \ldots \ldots\end{array}$ \\
\hline holidops $\mathrm{cf}$. areolata........... & halus cf. cristata. \\
\hline prpna sp................... & Boll \\
\hline yliolina fissurella.......... & B. obesa............. \\
\hline
\end{tabular}

The fossils from the other calcareous bands $(c-h)$ of the upper part of the section are not separately listed but are included together in the following list:

Productella sp.................. $\mathbf{r}$ Anoplotheca acutiplicata............ c

Chonetes buttsi n. sp...............r

Ambocœlia umbonata ................ c

Atrypa reticularis

A. cf. camilla.................... r

Odontocephalus ægeria............ c

Leperditia? cf. subrotunda.......... r

Hollidaysburg section.-The stratigraphic relations of the Onondaga fauna to the Oriskany and Helderberg formations are well shown just east of Hollidaysburg along the highway and railroad on the east side of Brush Run. The section exposed here begins in the Helderberg limestone and includes the Onondaga. It is as follows:

Hollidaysburg section (station 28).

Feet.

$m$. Fissile black clay shale

$20+$

l. Greenish-buff blocky clay shale, with Loxonema, Anoplotheca, etc. (Onondaga) ........................ 10

$k$. Fine-grained buff crumbling sandstone, mostly disintegrated to sand (Oriskany) .............................. $55 \pm$

j. Rather fine-grained buff, loosely cemented sandstone, with numerous typical Oriskany fossils.

$i$. Dark lead-gray, very fine grained calcareous sandstone, with Oriskany fossils (large Lingula, etc.)..................

$h$. Buff or drab, very fine textured thin-bedded rock of extremely light weight and highly porous texture in strata 2 to 10 feet thick. Originally a highly calcareous limestone from which the lime has been wholly leached. Trilobites, Chonetes,

Conularia, etc................................ 35

g. Dark-gray; somewhat calcareous but very siliceous shale.... 160

$f$. Bluish-gray limestone and some interbedded dark shale..... 15

e. Blue-gray, rather coarse limestone at top, finer at base; chert balls in upper portion; fossils common............... 20

$d$. Shaly gray limestone........................... 10

c. Drab or gray earthy argillaceous limestone, with numerous distinctly shaly bands; the whole fossiliferous.......... 65

b. Blue-gray, somewhat impure limestone, but with some bands of crystalline limestone not seen in preceding; very fossiliferous .........................................

a. Dove-gray fine-grained limestone of sublithographic texture, in thin strata mostly 1 to 3 feet thick; very few fossils..... 
With the exception of ostracodes, fossils are scarce in the Onondaga fauna at this point. From $l$ (station 28) the following species were secured:

Orbiculoidea lodiensis var. media ..... a | Bactrites aciculum................ r Anoplotheca acutiplicata............ $r$ Bollia ungula.................. c Loxonema cf. pexata

Leperditia? cf. subrotunda.

Canoe Creek section.-The richest locality for the Onondaga fauna which was visited in Blair County was discovered by Charles Butts 2 miles west of Canoe Creek at the side of the wagon road. The exposures here show the following beds:

Section 2 miles west of Canoe Creek, Blair County, Pa. (station 32).

$d$. Greenish-gray or drab argillaceous limestone, with trilobites, Atrypa reticularis, Anoplotheca, etc.

Ft. in.

c. Yellow, green, and black clay shale, light colored at top; numerous fossils.

$10-15$ .................... 20

b1. Calcareous shale, with trilobites.................. 6

b. Drab or greenish papery shale with Chonetes mucronatus, etc..................................... 12

$a$. Buff sandstone and concealed (Oriskany)........... 8

From the limestone band, $d$ of the section, the following fauna was collected:

Zaphrentis sp................. c

Ambocœlia cf. umbonata ............ c

Chonetes buttsi n. sp.............. c

C. $s p \ldots \ldots \ldots \ldots \ldots \ldots \ldots \ldots, \ldots, r$

Atrypa reticularis................... c

Anoplotheca cf. camilla............. r r

A. acutiplicata.
Stropheodonta inequistriata..........
Schuchertella cf. perversa..........
Pleurotomaria crassa $\mathrm{n} . \mathrm{sp} . \ldots \ldots \ldots \ldots .$.
Styliolina fissurella................
Dalmanites (Coronura) aspectans?...
Phacops cristata var. pipa...........

The fauna from the remainder of the beds, which were not separately marked on the collections, are shown in the following list:

Lingula cf. ligea

Orbiculoidea sp.

Pholidops of areolata.

Strophalosia truncata................ c

Chonetes mucronatus................. a

C. buttsi n. sp..................... c

C. cf. setigerus............, , . . c

Ambocœlia umbonata ............... $\mathrm{r}$

Schuchertella cf. perversa.......... r

Anoplotheca acutiplicata........... c

Palæoneilo cf. constricta ............ r

Panenka cf. multiradiata............. c

Nucula sp
Loxonema cf. pexata............... r

Naticopsis sp.................. $r$

Platyceras sp......................

Bellerophon cf. pelops.............. c

B. sp. undet.................. $r$

Coleolus curvatus n. sp.............. c

Tentaculites sp................ r

Hyolithes cf: aclis................ r

H. cf. principalis................ r

Styliolina fissurella................ a

Orthoceras cf. subulatum........... c

Octonaria stigmata................ r

Bollia obesa..................... $r$ 
MARYLAND.

General relations.-In Maryland the stratigraphic relations of the Onondaga shale do not differ greatly from those seen in Pennsylvania. In general the impure limestone which in Pennsylvania lies at the base of the Marcellus is somewhat less important in Maryland, being in many places almost, if not entirely, supplanted by the dark and drab shales. The sections embracing the Onondaga include at the base the coarse buff-brownish or white Oriskany sandstone, which in most places is about 250 feet thick, though sometimes differing widely from this, and which is followed above by drab or dark-colored shale holding the Onondaga fauna and some thin bands of impure limestone. The shales in which drab or light colors predominate are followed by others that are chiefly of the black fissile type representing the. Marcellus and that contain few fossils besides Leiorhynchus limitare and Styliolina fissurella. This Marcellus shale is overlain by shale and sandstone with typical Hamilton fossils.

The above-noted shales and sandstones, although embracing three distinguishable types of sediments and three very unlike faunas, have been classed together under the name Romney shale by the geologists of the Maryland Survey. Prosser ${ }^{1}$ recognized the facts that the upper arenaceous shales and sandstones contained a characteristic Hamilton fauna and that the fissile black shales just below them represented the Marcellus of the New York section. The whole of the shale series, amounting to a thickness of about 1,600 feet, includes not only a Hamilton and a Marcellus fauna, but an Onondaga fauna as well at the base of the Marcellus, the three having the same relative stratigraphic limits as in the New York section. The general relations of these three members of the Romney are well shown in the three railway cuts at Twenty-first Bridge, in western Maryland. In the northern part of the Baltimore \& Ohio Railroad cut at this locality the Hamilton fauna occurs abundantly. The Marcellus shale immediately below is nearly barren, except for Leiorhynchus limitare, which is abundant in the lower beds exposed at the south end of the same cut. Two cuts of the Western Maryland Railroad at Twentyfirst Bridge expose the Onondaga shale, about 100 feet thick, lying below the Marcellus, showing the 8 or 10 feet of limestones with Goniatites at its top and a part of the Oriskany at its base. At this locality fossils are scarce in the Onondaga, but Anoplotheca acutiplicata is the abundant and dominant fossil at the second cut west of Twenty-first Bridge, as it is at most other localities in the Onondaga shale.

Hancock section.-The Onondaga fauna has been observed at several localities along the Potomac, in outcrops east of Cumberland, 
and at Tonoloway and Hancock. The Onondaga fauna was found in green blocky clay shale on the hill northwest of Hancock, just east of the old sand quarry. About 60 feet above the Oriskany sandstone at this locality (station 41c, Hancock, Md.) the following fossils were secured:

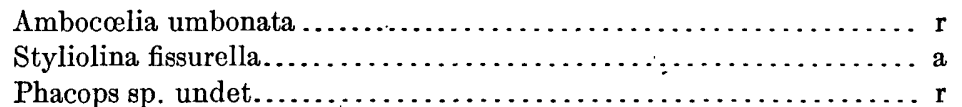

Typical thin, papery black shales of Marcellus type are exposed in the shale quarry about 50 feet above this fauna. The Marcellus here, as in most of the Allegheny sections, is largely concealed in the slopes of a valley excavated in the easily eroded beds of the Marcellus, which appear to have a thickness of not more than 400 feet at Hancock.

Tonoloway section.-The section at Tonoloway, opposite Great Cacapon, exposes nearly the whole of the Devonian below the Catskill, the only exception being the Marcellus, which is almost entirely concealed in the bottom of a small valley that reaches the Potomac along the strike of the beds of this portion of the section. At the base of the Marcellus, immediately above the Oriskany sandstone, about 60 feet of interbedded greenish-drab and black blocky shale representing the Onondaga is exposed. The following fauna was found in these beds (station $52 h$, Tonoloway, Md.) :

Strophalosia truncata............. $\mathrm{c}$ Styliolina fissurella.............. a

Rhipidomella vanuxemi ........... c Phacops cristata................ r

Ambocelia umbonata.............. c Bollia ungula.................. c

Nucleospira concinna............. c

Dalmanella lenticularis............ c

Anoplia cf. nucleata............... r

B. obesa..................... $r$

Craterellina ${ }^{1}$ n. g ............... r

Leptænisca australis $\mathrm{n} . \mathrm{sp} . . . . . . . . . \mathrm{r}$

Polygnathus sp. undet............ r

About 400 feet or more above the beds containing this fauna beds containing the typical Hamilton fauna appear in this section.

Cumberland section.-A section along the Williams road $3 \frac{1}{2}$ miles east of Cumberland, which shows a nearly continuous exposure of the beds from the Oriskany sandstone to the horizon of the Hamilton fauna, affords a clear conception of the essential characteristics of the different divisions of the Romney. Owing, however, to the presence of some minor folding and buckling of beds in the lower part of the section, to which Dr. Charles K. Swartz called the writer's attention, the precise thickness of some of the beds following the Oriskany sandstone can not be given. It appears that from this cause some of the beds of the Onondaga are duplicated, thus giving this member of the Romney a greater apparent thickness in this sec- 
tion than usual. Several successive faunules were collected from this section and their order of succession, beginning with a faunule from beds directly above the Oriskany sandstone, is indicated by the letters attached to them. The lowest division of the shales contains a profusion of individuals but a very small number of species, as indicated by the following list:

Lead-gray to black nonfissile shale 55 feet thick immediately above the Oriskany furnished the following species:

Orbiculoidea lodiensis var. media .... a $\mid$ Bactrites aciculum Anoplotheca acutiplicata............ a $\mid$ Enchostoma? sp.

A much more varied fauna occurs in the next division of the section, where the following species were found in part of division $c$ in argillaceous green and drab shales lying above the beds last named:

Station 45c, east of Cumberland, Md.

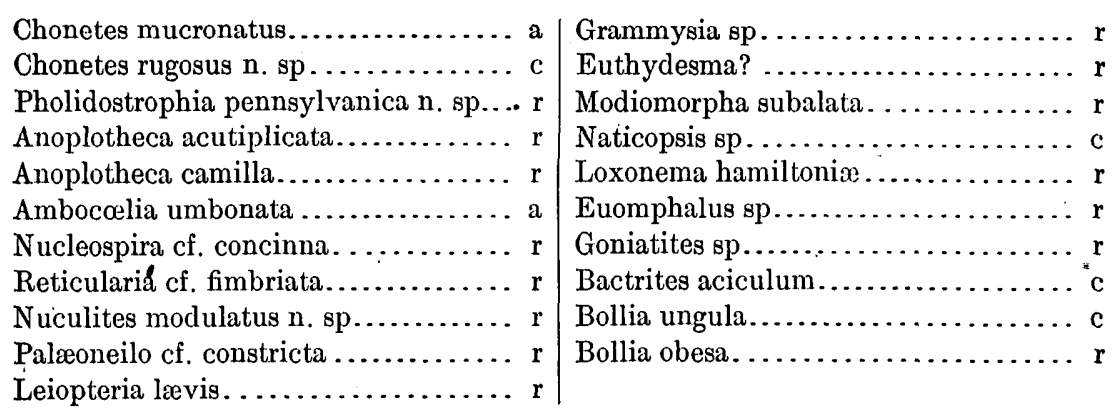

Although some species in this fauna, like Nuculites modulatus, are closely allied to or identical with Hamilton species, the presence of such species as Anoplotheca acutiplicata and Anoplotheca camilla, which have always been considered Onondaga or pre-Onondaga species, requires the assignment of this bed to the Onondaga horizon.

Still higher, in division $d$, we find the following species:

Station 45d, Cumberland, Md.

Pholidops cf. areolata

Anoplotheca acutiplicata

$\mathbf{r}$

Agoniatites cf. expansus.

This appears to be the highest fauna which shows definite affinities with the Onondaga.

In $g$ we find a Marcellus fauna, which is represented by the following congeries:

Station 45g, Cumberland, $M d$.

Strophalosia truncata. 
In this as in many other sections no very sharp line can be drawn between the sediments holding the Onondaga and the Marcellus faunas, the one grading into the other. Taken as a whole, however, the upper or Marcellus shales are decidedly blacker and comparatively freer from light-colored shales than is the lower series, in which green and drab-colored shales predominate.

The Tropidoleptus carinatus fauna was found in a bed of gray sandstone which lies not far above the base of the Hamilton member.

\section{WEST VIRGINIA.}

General conditions.-The belts of Lower Devonian rocks which cross Maryland in conformity with the Allegheny structure continue southward across the Potomac through northeastern West Virginia, with a south-southwesterly trend. The two belts of Devonian rocks on opposite sides of the New Creek Mountain anticline in Mineral County are the most westerly of the Lower Devonian rocks which reach the surface in West Virginia. Collections representing the Onondaga fauna were made from both of these belts, one at Rees Tannery, at the foot of the Allegheny Front, and the other at Ridgeville. Another section, including these rocks, was studied farther east, at Berkeley Springs.

The coarse Oriskany sandstone everywhere lies at the base of the Devonian shale series in West Virginia, as it does in Maryland and Pennsylvania. The Oriskany is well exposed in the vicinity of Keyser, where the New Creek Mountain uplift is cut through by the Potomac. Nearly opposite the station at Keyser the Oriskany rises above the Potomac and, arching up in New Creek Mountain almost vertically 400 feet above the river, forms the bold cliff at Queens Point opposite Keyser. South of the Potomac the east and west slopes of the New Creek Mountain ridge are each flanked by a belt of the Oriskany sandstone. Immediately above this formation in the section is the shale series called the Romney shale in the United States Geological Survey folios ${ }^{1}$ that describe this region and the Hamilton shales by the West Virginia State Survey. ${ }^{2}$ Neither of these terms is entirely satisfactory. The use of the term Hamilton involves the correlation of beds of Onondaga, Marcellus, Hamilton, and Portage age with the Hamilton formation of New York, which is manifestly indefensible. The use of the term Romney avoids questions of correlation, and in the ordinary formational sense, with various members, it is convenient and useful (p.. 18). As used in this bulletin the name Onondaga shale member is applied to the lowest lithologic division of the Romney, including the calcareous bands and lighter-colored shales near the base of the Romney.

1 Follos 28, 32, Geol. Atlas U. S., U. S. Geol. Survey, 1896.

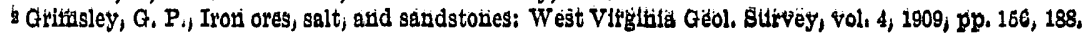


Ridgeville section.-The territory between Ridgeville and Berkeley Springs includes the type area of the Romney shale. Three distinct and successive faunas-Onondaga, Marcellus, and Hamilton-are included in the rocks assigned to this formation by Darton. ${ }^{1}$ The three types are limited, respectively, to three types of sediments which comprise the Romney. The lowest of these includes mainly alternating drab or green and black clay shales with a few thin bands of impure limestones. Following these are a series of generally fissile black shales with comparatively few drab or light-colored shales. The uppermost division includes drab sandy shales and sandstones with the Hamilton fauna. These two upper divisions in the more easterly sections are sharply differentiated lithologically, as at Hedgesville and Hancock. The different faunal and lithologic elements of the Romney shale are shown in the Ridgeville section, which is exposed on the east slope of New Creek Mountain along the wagon road near Ridgeville post office. It is as follows:

Ridgeville section, on east slope of New Creek Mountain, near Ridgeville,

W. Va. (station 51). Feet.

e. Drab sandy shale, becoming softer upward............... $300 \pm$

d. Black to lead-gray carbonaceous fissile clay shale............ 250

c. Greenish-drab shale and impure limestone as below, fossils common................................... $50 \pm$

b. Black and greenish interbedded clay shale, with bands of greenish earthy and very impure limestone near top; fossils abundant................................... $75 \pm$

a. Brownish-buff sandstone with Oriskany fossils (Oriskany sand-

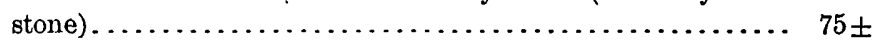

It will be noted that in the lower 150 feet of this section above the Oriskany light-colored beds predominate, whereas in the next 250 feet they are nearly or entirely absent. The lower 75 feet of shale, $b$, is characterized by the following fauna, indicating its Onondaga age:

Orbiculoidea lodiensis var. media..... c $\mid$ Nucula cf. corbuliformis........... r Lingula cf. ligea............... $\mathbf{r}$ Cypricardinia $s p \ldots \ldots \ldots \ldots \ldots \ldots$ Craniella hamiltoniæ............. c Lunulicardium curtum.......... r Pholidops cf. areolata.............. c Strophalosia truncata. .............. c Chonetes sp................... c Dalmanella lenticularis............ $\mathrm{r}$ Ambocœlia umbonata............ $r$ Anoplotheca acutiplicata............. a Cranæna cf. romingeri. ........... r $\mathbf{r}$ Pholidostrophia pennsylvanica $n$. sp... $\mathrm{r}$ Rhipidomella vanuxemi........... $\mathbf{r}$ Nuculites modulatus $\mathrm{n} . \mathrm{sp} . . . \ldots \ldots . \mathrm{r}$ Panenka cf. dichotoma ............ r Aviculopecten equilatera. ......... $r$ Actinopteria muricata............ c Platyceras sp................... r Naticopsis sp................. r Loxonema hamiltoniæ............ c Orthoceras sp. (small sp.).......... r $r$ Bactrites aciculum ?............. $r$ Hyolithes cf. aclis............... $r$ Phacops cristata................ $r$ Conolichas hispidus ?.............. $r$ Cryphæus cf. boothi var. calliteles.... c Bollia obesa................... c 
In $c$ of the section the fauna is similar to that of $b$, but less abundant. In the next division, $d$, the fauna is very meager. Unlike the preceding fauna, it includes no characteristic Onondaga species. In the lower part of $d(d 1)$ the following species, one of which may be regarded as a characteristic Marcellus fossil, are found:

Station $51 d 1$ :

Strophalosia truncata. . . . . . . . . . . . . . . . .

Leiorhynchưs limitare $\ldots \ldots \ldots \ldots \ldots \ldots \ldots \ldots \ldots \ldots \ldots \ldots \ldots$

In the upper part, $d 2$, ocsurs the following faunule:

Station 51d2:

Chonetes cf. scitulus.................................

Leiorhynchus limitare. .............................

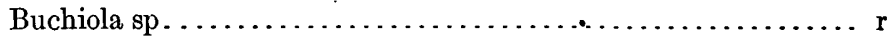

Both of these faunules are regarded as representing the Marcellus fauna. The beds containing them are overlain by a drab sandy shale, $e$, containing a very different fauna, in which the two most common species are Chonetes setigerus and Tropidoleptus carinatus. The presence of Tropidoleptus carinatus plainly indicates the Hamilton. The Hamilton fauna here appears to be rather meager, but farther east, at Hedgesville, the sandstones and shales of the Hamilton afford a fauna which in the number of species represented is as rich as at the average locality in central New York.

Rees Tannery section.-At Rees Tannery, station 50a, about $2 \frac{1}{2}$ miles west of the section just given, the lower part of the Romney afforded the following fauna, representing the Onondaga:

Zaphrentis sp................... $\mathbf{r}$ Nucleospira concinna............ r Orbiculoidea lodiensis var. media..... c Styliolina fissurella.............. a Ambocœlia cf. nana............... $r$ Dalmanites sp. undet............. $r$ Dalmanella lenticularis........... $r$ Phacops cristata................. c Anoplia nucleata ............... $r$ Bollia ungula............... c Anoplotheca acutiplicata.

Berkeley Springs section.-About $1 \frac{3}{4}$ miles south of Berkeley Springs, W. Va., the wagon road cuttings expose the Oriskany sandstone and the lower portion of the Romney including most of the shales holding the Onondaga fauna. The following section was noted here:

Section $1 \frac{3}{4}$ miles south of Berkeley Springs (station 43).

$f$. Fissile black shale, and covered .................... 250

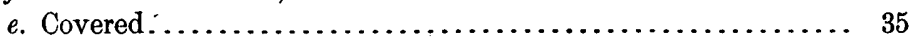

d. Black blocky argillaceous shale, full of fossils........... 20

c. Drab shale, weathering cherry-red in places; fossils scarce...... 18

$b$. Cream or light putty-colored clay and shale, with some buffish layers........................................ 10

a. Buffish-brown sandstone, crumbling to sand (Oriskany) ....... $60+$ 
The lowest fossils observed in the shales of this section occur in $c$; they are Craniella hamiltonix, Leptostrophia perplana, and Ambocelia umbonata.

In $d$ occurs the following fauna:

Chonetes sp. ................. r

Ambocœlia umbonata............. a

Nucleospira concinna. . . . . . . . . . c

Anoplia nucleata .............. c

Dalmanella lenticularis. . . . . . . . . a

Leptænisca australis $n$. sp........... c

Pholidostrophia pennsylvanica n. sp... r
Nucula cf. corbuliformis........... r

Cypricardinia ? sp............... r

Styliolina fissurella.............. a

Phacops cristata................ c

Cyphaspis cf. stephanophora. ....... r

Leperditia ? cf. subrotunda.......... r

The Marcellus in the section is imperfectly exposed and no fossils were observed in it.

Romney.-At the type locality of the Romney shale, Romney, W. Va., two faunas - the Onondaga and the Hamilton-are found. The meager Marcellus fauna is doubtless also present, though not observed. These faunas occur, respectively, in the lower and upper parts of the Romney. In the vicinity of Romney the Onondaga shale member may be seen along the road through Mill Creek Mountain Gap, $1 \frac{1}{2}$ miles southwest of town.. Here the section shows an abrupt transition from the gray, highly calcareous coarse sandstone full of Oriskany fossils to drab shale, approximately 100 feet thick, with some calcareous bands containing. the Onondaga fauna. Fossils are not so readily found as at many other localities. Among those collected are Anoplotheca acutiplicata, Dalmanella lenticularis, and Ambocolia umbonata.

The black shale representing the Marcellus is well exposed on the opposite side of the south branch of Potomac River and appears to be barren. A little higher up the hill to the eastward on the west side of Romney the black fissile shale is succeeded by olive to gray slightly sandy shale with Hamilton fossils, which may be collected near the railroad station at Romney.

Moorefield.-The Onondaga fauna occurs abundantly and in a good state of preservation 2 miles west of Moorefield along the road to Maysville. The stratigraphic relations of the beds here, however, are not clearly defined and the outcrops do not afford a very satisfactory section. At Maysville the Onondaga, together with the beds above and below it, is well exposed at the eastern end of Cosner Gap through New Creek Mountain. At this locality, as at many others, Anoplotheca acutiplicata is the most conspicuous fossil.

Fort Seybert.-The Onondaga doubtless occurs as far south in West Virginia as White Sulphur Springs, but Fort Seybert, in Pendleton County, is the most southerly point in this State at which the Onondaga fauna was collected. About one-half mile south of Fort Seybert the drab and dark shale of the Onondaga outcrops at the 
side of the Brandywine road. The fauna found at this point includes among other species Dalmanella lenticularis, Anoplotheca acutiplicata, Phacops cristata, and Bollia ungula. A typical Hamilton fauna, represented by a great abundance of fossils, occurs near this locality.

\section{VIRGINIA.}

General relations.-The shales in Virginia which contain an Onondaga fauna, except those in the extreme southwestern part of the State, have been included with the shales of Marcellus and Hamilton age under the name Romney shale in the folios of the United States Geological Survey. In the Bristol folio the term Romney is not used, and a considerable portion (at least 500 to 800 feet) of the beds which farther north are called Romney are known as the black Chattanooga shale. In the Staunton quadrangle 600 to 1,000 feet of dark shales are assigned to the Romney. The typical Hamilton fauna, which in Maryland and West Virginia characterizes the upper part of the Romney shale, has in central and southwestern Virginia given place to a facies of very different type from that found farther north. Except in the extreme southwestern part of the State, however, the Onondaga fauna, with which this paper is chiefly concerned, shows no important deviation from the facies seen in West Virginia and Maryland. At Big Stone Gap a distinct facies with a coralline fauna appears. With this exception the Onondaga fauna continues . to occupy the basal portion of the Devonian shale series in Virginia as in the more northerly States. In the region of James River it occurs in the lower part of the Romney, and nearer the Tennessee line it lies just at the base of the Chattanooga shale. The components of this fauna and its stratigraphic relations will be shown in the descriptions of some of the representative sections. In the James River region and northward, where the Onondaga shale grades into the next higher division of the Romney, it may conveniently be treated as a member of the Romney shale. In southwestern Virginia, the transition is an abrupt one, the Onondaga limestone being followed by a black shale called the Chattanooga shale. As the Onondaga is here only 5 feet thick - too thin to map-and as it has been included in the Chattanooga shale of this region, it will be treated as a member of the Chattanooga, as to the north it is treated as a member of the Romney shale.

Hayfield.- South and southwest of the sections which have been described in West Virginia the Onondaga shale may be found at the proper horizon along most of the wagon roads which cross the country at right angles to the general strike. The fauna of this shale occurs along the road from Winchester to Capon.Bridge and abundantly at Hayfield, where limestone beds comprise an important 
element in the Onondaga shale member. Anoplotheca acutiplicata occurs in them in abundance. A few hundred yards west of Hayfield the Oriskany is seen in the wagon road at the base of the Onondaga.

Shenandoah Alum Springs.-About 45 miles southwest of Hayfield • a small collection of the Onondaga fauna was made on the east side of North Mountain at Shenandoah Alum Springs. The fauna occurs here in drab-colored shales, which may be seen at the rear of the old iron-ore furnace. Among the fossils collected are Phacops cristata, Acidaspis callicera, and Octonaria cf. stigmata.

The section including the Onondaga is as follows:

Shenandoah Alum Springs section.

Feet.

Drab ash-colored shale, with Hamilton fossils at base......... $60 \pm$

Fissile black shale, with one or more bands of limonite ore. In lower part occur thin bands of very soft carbonaceous matter, with some large concretions of black limestone; fossils rare....... $300 \pm$

Drab to cream-colored shale, with Onondaga fossils........... $35 \pm$

Gray sandstone, coarse, conglomeratic, with typical Oriskany fossils..................................... $50 \pm$

Owing to structural complications it is impossible to give more than a rough estimate of the thickness of the Oriskany sandstone and the Marcellus member of the Romney at Shenandoah Alum Springs. The relationship of the Onondaga shale member to these beds, however, is perfectly clear; although its precise thickness was not determined.

Stribling Springs.-About 40 miles southwest of Shenandoah Alum Springs a portion of the Onondaga shale member appears to be partly exposed in the section at Stribling Springs just below the hotel grounds. The Oriskany, and apparently a part of the Onondaga member, is here cut out of the section by faulting.

Bells Valley.-Twenty-five miles southwest of Stribling Springs, along the trend of the structure, the following excellent section of the Lower Devonian rocks is exposed at Bells Valley, between the quarry and the church south of the station.

\section{Section at Bells Valley, Va. (station 57).}

l. Hard thin sandy shale and thin-bedded sandstone, with abundant Pararca, etc............................ $100+$

$k$. Drab to buffish soft clay shale, with Portage fossils........ $60 \pm$

$j$. Fissile black shale, with some bands of impure limestone..... $150 \pm$

$i$. Drab and dark lead-colored soft shale, with lenses and concretions of dark limestone; Buchiola speciosa very abundant. ... $60 \pm$

$h$. Covered ................................. $40 \pm$

g. Fissile black, much crumpled shale ................ 50

$f$. Drab and greenish soft clay, with some very thin bands of black shale holding a rich fauna....................... 25

e. Covered.................................. $40 \pm$

d. Drab to greenish blocky shale, with some slightly limy bands.. 45 
Feet.

c. Soft brownish sandstone, crumbling to sand (Oriskany)...... $35 \pm$

$b$. Dark-blue limestone, some chert lentils in upper part, and numerous fossils............................... $45 \pm$

a. Gray crystalline limestone....................... $50 \pm$

The first three divisions of this section above the Oriskany sandstone are referred to the Onondaga shale member of the Romney shale. In the lower shales, $d$, immediately above the Oriskany sandstone the following fauna occurs:

Orbiculoidea lodiensis var.media ..... c $\mid$ Buchiola sp..................... r

Strophalosia truncata. ............ c Bellerophon leda................ r

Nucleospira concinna?............. r Phacops rana.................... a

Cranæna cf. romingeri .............. a Bollia ungula.......................

Anoplotheca acutiplicata............ $\mathrm{r}$ Bythocypris favulosa...............

Similar to the above is the following fauna, which occurs in the next exposed division, $f$ :

Chonetes mucronatus. ............ $\mathrm{r} \mid$ Nucula corbuliformis............. r $r$

Leiorhynchus cf. limitare......... c Bellerophon leda............... r

Anoplia nucleata................ c Pleurotomaria sp.............. r

Ambocœlia umbonata ............ a Tentaculites gracilistriatus......... c

Anoplotheca camilla............., $\mathrm{r}$ Styliolina fissurella................ c

Actinopteria sp.................. c Bactrites cf. aciculum............ r

Buchiola sp.................. r r Bollia obesa................... c

Leptodesma sp................. $\mathrm{r}$

The next division, $g$, changes from predominating drab or lightcolored shales to black shale, and with this lithologic modification occurs a very marked change in the type of the fauna:

Leiorhynchus limitare. . . . ........ a $\mid$ Buchiola retrostriata.............. c

Leiorhynchus nysius.............. c Styliolina fissurella.............. a

Nuculites modulatus $\mathrm{n} . \mathrm{sp} . . . \ldots \ldots, \mathrm{r}$ Coleolus tenuicinctum............. r

In this fauna Buchiola retrostriata and Leiorhynchus nysius make their first appearance in the section as common or dominant species. Simultaneous with the appearance of these species in abundance is the disappearance from the section of Anoplotheca acutiplicata and Anoplia nucleata. The Onondaga fauna may therefore be considered to be limited to the shales $d, e$, and $f$.

In this region the Hamilton fauna has so completely lost the features which distinguish it farther north from the Marcellus that it is hardly practicable to separate the two faunas. The following fauna, $i$, and the one just listed are the representatives of this portion of the Devonian fauna in this section:

Chonetes cf. mucronatus............ $\mathbf{r}$ Orthonota? sp................ $\mathrm{r}$

Leiorhynchus limitare. . . . . . . . a a Styliolina fissurella.............. c

Buchiola halli................ a $\mid$ Goniatites sp................... r 
This fauna is followed by a typical Portage fauna of the western New York type. Still higher in the section and preceding the Chemung faunas is found the eastern Portage or Ithaca fauna.

Clifton Forge.-Near Clifton Forge, Va., the Onondaga member is well exposed along the Chesapeake \& Ohio Railway, both east and west of town. The following section is exposed along the railroad one-half mile west of the station:

Section west of Clifton Forge, Va. (station 58).
e. Drab and greenish shale
Feet.
d. Yellow and olive shale and sandstone.
$100 \pm$
c. Brownish-gray sandstone, with Oriskany fossils.
20
b. Gray subcrystalline limestone, with thin chert lentils in lower part. .
$a$. Black chert and interbedded limestone \} Helderberg ... $\begin{aligned} & 36 \\ & 54\end{aligned}$

In this section the angular unconformity between the Oriskany sandstone, $c$, and the Helderberg limestone, $a$ and $b$, is well shown at the side of the railroad. The slight thickness of the Oriskany in this section is evidently due to the unconformity, the greater part of it being absent. The Onondaga shale member is represented by the remainder of the section, $d$ and $e$.

The following fauna occurs in the lower 20 feet of the shale, $d$ :

Zaphrentis cf. simplex........... $\dot{\mathbf{r}} \mid$ Anoplotheca acutiplicata........... c

Procteria sp.................... r Pleurotomaria cf. trilix............ r

Pholidops sp................... $\mathrm{r}$ Actinopteria muricata............. c

Orbiculoidea lodiensis var. media.... $\mathrm{r}$ Styliolina fissurella.............. a

Ambocœlia umbonata. ........... r r Phacops cf. cristata.............. r

Strophalosia truncata. . . . . . . . . . r $\mathrm{r}$ Bollia ungula................... c

Anoplia cf. nucleata.............. $\mathbf{r}$ Ostracodes undet.............. a

Dalmanella lenticularis............ c

Three-fourths of a mile east of the Clifton Forge railroad station the railroad cuts expose the following section:

Section east of Clifton Forge, Va. (station 59).

Feet.

d. Black fissile shale, crushed and crumpled................ $100 \pm$

c. Drab or greenish shale, slightly calcareous and blocky near base. 45

$b$. Brownish coarse sandstone (Oriskany) ................. 12

a. Gray crystalline limestone........................ $5+$

The Onondaga ofauna is represented in the drab ohales, $c$, by the following fauna:

Cladopora sp.

Dalmanella lenticularis?............ c

Zaphrentis sp

Anoplotheca acutiplicata........... c

Crinoid stems.

Platyceras sp.................. $r$

Orbiculoiden sp......................

Anoplin sp .......................

Odontocephalus ægeria ............ r

Anoplia sp..............

Bollia ungula.................... c

Bythocypris favulosa............... $\mathbf{r}$ 
Mountain Grove.-Throughout the James River region the Onondaga shale member is characterized by an Onondaga fauna of the type seen in the preceding lists. Anoplotheca acutiplicata is generally present. The most westerly locality in this district in which this fauna was collected is at Mountain Grove, Bath County, near the West Virginia line. In the western part of Bath County the valley of Back Creek is cut for many miles in the soft shales of the lower part of the Romney. On one side of it the Oriskany sandstone and lower beds of more resisting character form Back Creek Mountain. On the other side the hard sandy shales of the Jennings. and Hampshire formations have given rise to the long mountain ridge called Little Mountain. At Mountain Grove Little Back Creek has cut directly across these formations and the Romney formation, exposing a good section of the rocks. The generally westerly monoclinal dip along this stream is somewhat complicated by local flexures, which make accurate estimates of the thicknesses of the lower subdivisions of the Romney impracticable. The general succession, however, is clearly indicated and is shown in the following section, in which the thicknesses are for the most part only approximate:

Mountain Grove section (station 61).

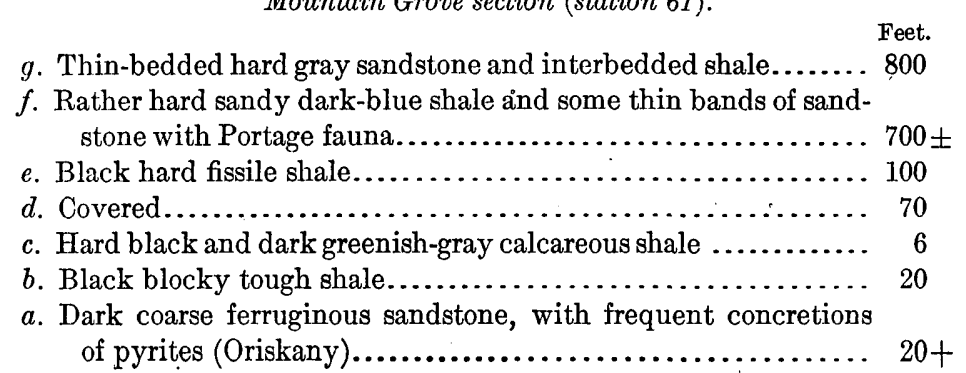

In the calcareous shale, $c$, near the base of the section the following species were found:

Orbiculoidea lodiensis var. media......................... a

Anoplotheca acutiplicata............................. c

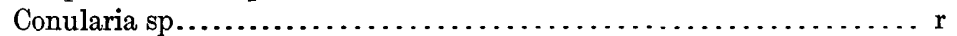

No fossils were found in the fissile black shales, $e$, which probably represent the Marcellus and Hamilton. Above these beds in hard sandy shales occurs a typical Portage fauna, and this is followed by the Chemung fauna in $g$.

Catawba Mountain.-About midway between James and New rivers a section was studied on the southeast slope of Catawba Mountain. The Onondaga shale member is exposed along the Red Sulphur Springs and Salem road, 7 miles northwest of Salem, and a short distance above the railroad. A portion of the section follows: 
Catawba Mountain section.

c. Feet.

c. Fissile black and drab shale, largely covered................ 1.00+

$b$. Light ash-colored or drab argillaceous soft shale (Onondaga

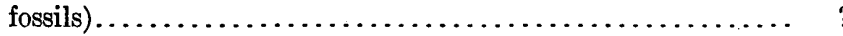

a. Coarse crumbling white sandstone with a few thin bands of purple sandstone; only a few small fragments of fossils seen... 200土

The light-colored argillaceous shale, $b$, contains Zaphrentis cf. simplex, Cladopora sp., Leptænisca-australis n. sp., Dalmanella lenticularis, Anoplotheca acutiplicata, Odontocephalus xgeria, Bollia ungula.

Little Walker Creek.-South of New River the Onondaga fauna is still associated with light-colored somewhat calcareous shales at or near the base of the Romney, which, together with shales above and below it, are exposed in the Little Walker Creek gap through Walker Mountain and along the highway east of the gap across Little Walker Mountain, in Bland County, $7 \frac{1}{2}$ miles northwest of Dublin, as shown in the following section:

\section{Little Walker Creek section (station 66).}

$h$. Drab sandstone and interbedded shale of light color, which crumbles readily to small many-sided fragments; typical Chemung fauna............................... $670+$

g. Tough, hard dark-gray siliceous shale merging into $f$ at base, with thin sandstone bands above; Portage fossils at base...... $600 \pm$

$f$. Black hard fissile shale ............................. 250 \pm

$e$. Covered and dark shale, calcareous near the base (not seen in the creek section but outcrops at the roadside about one-half mile up the valley, near a spring)..................... $75 \pm$

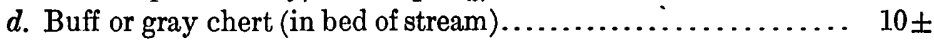

c. Soft coarse gray sandstone (Oriskany?)(in bed of stream)....... 20

$b$. Hard dark-gray calcareous fine-grained sandstone (in bed of stream) $\ldots \ldots \ldots \ldots \ldots \ldots \ldots \ldots \ldots \ldots \ldots \ldots \ldots \ldots \ldots \ldots \ldots \ldots \ldots \ldots \ldots, 2$

a. Hard gray quartzite...................................

The fauna which in this section is referred to the Onondaga occurs about one-half mile southwest of the gap at a spring by the side of the road to Sassin in a dark shaly limestone or calcareous shale. The species obtained here (station 66e) are the following:

Zaphrentis sp

Aulopora sp.

Chonetes cf. mucronatus. .......... r

Ambocœlia cf. nana................ à

Buchiola halli.................... a

Pterochænia fragilis............... c
Naticopsis sp.................. c

Parodiceras discoideum............. c

Bactrites cf. aciculum............. c

Tentaculites gracilistriatus.......... c

Phacops cristata var. pipa......... a

This faunule, it will be noted, indicates some departure in its composition from those previously listed and shows a greater contrast with the typical Onondaga facies than any of those hitherto recorded. 
The presence of Pterochænia fragilis, Buchiola halli, and Parodiceras discoideum might suggest that itorepresented the Marcellus or Hamilton were it not for the presence of the Onondaga trilobite, Phacops cristata var. pipa, which has not been recorded from beds younger than the Onondaga; for the two lamellibranchs named are known to have a long range, Pterochænia fragilis occurring in the Marcellus, Hamilton, and Portage in New York. Moreover, the faunal succession also suggests its Onondaga age. Though it is possible that this faunule represents the Marcellus it is placed provisionally with the Onondaga fauna.

In the black shale comprising the next division of the section the fauna seems to be limited to. a single species, Schizobolus concentricus, which occurs in abundance. This fauna is followed in the more sandy beds, $g$, higher up by a Portage fauna in which Paracardium doris is the dominant species. In the faunule from Little Moccasin Gap, next to be given, the intrinsic evidence of the fauna points unmistakably to its Onondaga age. An important fact about the Little Moccasin Gap faunule in this connection is that it is immediately followed by black shale in which Schizobolvos truncatus, as in the Little Walker Creek section, is the most abundant if not the only species. Thus both of these Onondaga faunules, though somewhat diverse in type, are directly followed by the Schizobolus truncatus fauna.

Little Moccasin Gap.-About 50 miles southeast of the Little Walker Creek section, at Little Moccasin Gap, 9 miles northwest of Abington, the greater portion of the Devonian section is exposed. The lower portion of the section as exposed in the vicinity of the gap is as follows:

\section{Little Moccasin Gap section (station 71).}

e. Greenish, buffish, and brownish clay shale, with Buchiola speciosa, etc. (Portage fauna) .................... 15

d. Black, gray, and greenish clay shale, fissile and carbonaceous where black and more or less blocky elsewhere........... 200土.

c. Hard blue argillaceous limestone, weathering to a buff soft blocky kind of shale similar to that generally representing the Onondaga. Chonetes carinatus, Chonetes mucronatus, etc. (rich fauna)............................. $5 \pm$

b. Hard cherty and sandy limestone, chert predominant and rocks generally appearing as a chert bed.................. 2-4

a. Dark lead-gray to brownish sandstone................. $6+$

The greenish shales, $e$, at the top of the section contain a.Portage fauna. In the fissile black shale element of the beds below, $d$, Schizobolus truncatus occurs in abundance, but apparently no other species. The Onondaga is represented by about 5 feet of argillaceous 
limestone, $c$, at the base of the shales, from which the following species were obtained:

Stictopora sp.................. c

Pholidops cf. areolata............ r

Strophalosia cf. truncata . . . . . . . . r

Chonetes mucronatus............. c

C. arcuatus.................. a

Ambocœlia umbonata ............ r

Schuchertella pandora............ r

Rhipidomella vanuxemi......... r

Atrypa reticularis................ $\mathrm{r}$

Stropheodonta cf. patersoni......... c
Spirifer disparalis.............. c

Merìstella nasuta . . . . . . . . . . . . r

Pentagonia unisulcata?........... r

Pterinea sp. undet............... c

Cypricardinia indenta........... c

Leiopteria cf. bigsbyi. . . . . . . . . r r

Conocardium cf. cuneus var. nasutum . . r

Odontocephalus ægeria?.......... r

Leperditia? cf. subrotunda......... r

Bythocypris favulosa............ c

Mendota.-About 15 miles south of Little Moccasin Gap, at Mendota, another collection was obtained, representing a facies of the Onondaga fauna very similar to that shown by the preceding list. The stratigraphic relations of the beds holding the fauna are similar to those which have been described at Little Moccasin Gap. Near the head of a ravine northwest of the schoolhouse at Mendota the rather coarse gray or brownish sandstone is followed by about a foot of hard blue argillaceous limestone weathering to soft fine-textured shaly rock of light-buff color. The sandstone appears to lie within the limits of Campbell's Hancock limestone $;^{1}$ the limestone is included in the Chattanooga shale of the folios on that region. The following species were collected from the limestone (station $72 l$, Mendota, Va.):

Zaphrentis sp................. r

Crinoid stems................. a

Strophalosia truncata........... r

Pholidops cf. areolata............ a

Chonetes lineata................. r

C. mucronatus.................. c

C. arcuatus.................... a

Stropheodonta $\mathrm{sp} . . . \ldots . \ldots . \ldots . \ldots . \mathrm{r}$

Camarotœchia sp . ............ r

Anoplia nucleata .............. a

Meristella nasuta. ............. r

Stropheodonta patersoni......... r

Spirifer cf. fimbriata.............. r

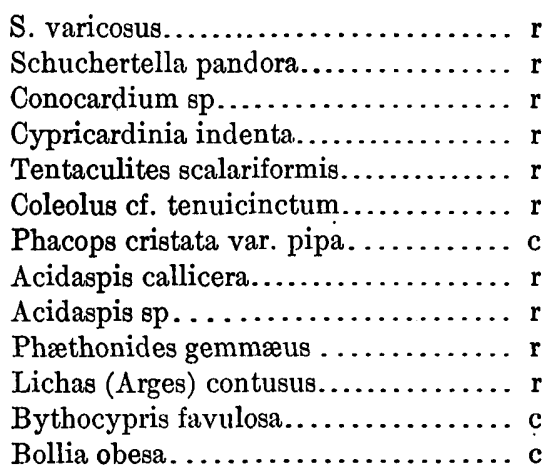

The beds following this fauna are black fissile shales having a thickness of more than 100 feet. The fauna characterizing these black shales (station 72k, Mendota, Va.) is indicated by the following list:

Schizobolus concentricus.

a Tentaculites sp.

Chonetes mucronatus.

Actinopteria sp.

Styliolina fissurella.

1 Campbell, M. R., Folios 59, 12, Geol. Atlas U. S., U. S. Geol, Survey.

$20495^{\circ}-\mathrm{Bull} .508-12-4$ 
In this, as in the two preceding sections, Schizobolus concentricus is the dominant species of the fauna following the Onondaga fauna. Instead of appearing alone, however, as in the other sections, it is here associated with species, common in the Marcellus shale. Schizobolus concentricus has been generally regarded as a Genesee species and was recorded only from the Genesee by Schuchert. ${ }^{1}$ In the Eighteen Mile Creek section, however, Grabau ${ }^{2}$ reported it to be "absent or unknown in the Genesee horizon but present in the Moscow shale below Genesee." More recently this species has been recorded from the Marcellus at Lancaster, N. Y. ${ }^{3}$ The Mendota section affords another example of its occurrence with a fauna of earlier horizon value than the Genesee. Marked uniformity in conditions of sedimentation prevailed in Virginia and West Virginia from the end of the Onondaga to the beginning of Portage sedimentation, as is attested by the uniform character of the black shales representing this interval in the sections. Hence the diverse faunas which characterize the Marcellus, Hamilton, and Genesee in central New York can not be expected in this region. In southwestern Virginia there is found, instead, between the Onondaga and Portage faunas, a fauna which in some sections appears to consist solely of the one species Schizobolus concentricus, although in places it is associated with a few other fossils, as shown in the last list of species given. This occurrence of the Onondaga fauna carries its southern range to within 8 miles of the Tennessee boundary. The fissile black shale which follows the lighter colored shales holding the Onondaga fauna in Virginia continues on across Tennessee into Georgia and Alabama. In Tennessee, however, the Onondaga fauna has not been found and is believed to be absent. At Clinch Mountain, northwest of Rutledge, Schizobolus concentricus is abundant in the Chattanooga shale.

Big Stone Gap.-In the region northwest of Mendota the principal change in the lower part of the Devonian section consists in the great thickening of the series of beds called the Hancock limestone. A thickness of 180 to 275 feet is credited to this formation in the Estillville quadrangle by Campbell, ${ }^{4}$ who describes the formation as "blue fossiliferous limestone, very sandy at top and bottom." A section intended to illustrate the relation of the upper part of these beds to the black shales, together with a list of one of the faunas characterizing them, has been published by Kindle. ${ }^{5}$ Apparently both Campbell and Kindle overlooked a series of interbedded gray limestones

1 Synopsis of American fossil Brachiopoda: Bull. U. S. Geol. Survey No. 87, 1897, p. 372.

8 Grabau, Amadeus, Bull. Buffalo Soc. Nat. Sci., vol. 6, 1899, p. 17.

3 Wood, Elvira, Bull. New York State Mus. No. 49, 1901, p. 157.

4 Estillville folio (No. 12), Geol. Atlas U. S., U. S. Geol. Survey, 1894.

5 Williams, H. S., and Kindle, E. M., Contributions to Devonian paleontology, 1903: Bull. U. S. Geol, Survey No. 244, 1905, p. 28. 
and black cherts which lie just above the sandy beds of the Hancock, separating them from the black shales above. These uppermost limestones with their black cherts present a striking physical resemblance to the typical Onondaga limestone of New York State. Theypresent, moreover, a marked lithologic contrast to the beds which immediately precede them. The latter, where leached by surface waters, in many places resemble sandstone more than limestone and in many places hold thin bands of quartz conglomerate in which pebbles 1 to 2 inches in diameter are not rare. The faunal contrast is as marked as the lithologic. The fossils present are almost entirely corals, which occur in such numbers as to form practically a coral reef. The fauna of these cherty limestones indicates that they should be correlated with the Onondaga limestone. In the Estillville folio they were included in the Chattanooga shale.

Reexamination of the section at Big Stone Gap previously described by Kindle from exposures along the Louisville \& Nashville Railroad, on the northwest side of town, failed to disclose the presence there of the beds under discussion. In that section the crumbling sandy beds of the Hancock limestone appear to be overlain directly by the black shale. This seems to indicate the local absence, probably through erosion, of the coralline limestone. The stratigraphic relations of this limestone and chert bed are shown in the following section, which is exposed under the old woolen mill on the southeast side of Big Stone Gap:

Woolen Mill section, Big Stone Gap. • $\quad$ Feet.

Fissile black shale................................ 20

Gray coralline limestone and interbedded black chert........... 8

Buff or brownish, somewhat calcareous sandstione ........... 20+

Another locality where this bed may be advantageously studied is $1 \frac{1}{2}$ miles northeast of Big Stone Gap, at the cave entrance on the opposite side of the highway from the sink of Wild Cat Creek, where a greater thickness of both the Hancock limestone and the Chattanooga shale is exposed.

Wild Cat Creek section.

Feet.

Fissile black shale................................ $35+$

Gray limestone and interbedded gray or black chert; corals in

great abundance...................................

Gray subcrystalline limestone, with much sandy and argillaceous matter in the upper part; many of the higher beds weather to a buff fine-grained sandstone; fossils abundant............ 60

Hard dark close-grained limestone, with very few fossils....... 50 
The following fauna, which characterizes the coralline limestone, is identical in the Wild Cat Creek and Woolen Mill sections:

Zaphrentis cornicula.

Z. cf. prolifica.

Cystiphyllum americanum.

C. sulcatum.

Blothrophyllum decorticatum.

B. americanum.

Heliophyllum halli.

H. cf. annulatum.

Diphyphyllum cf. gigas.

Cladopora cf. expiata.

C. cf. bifurca.

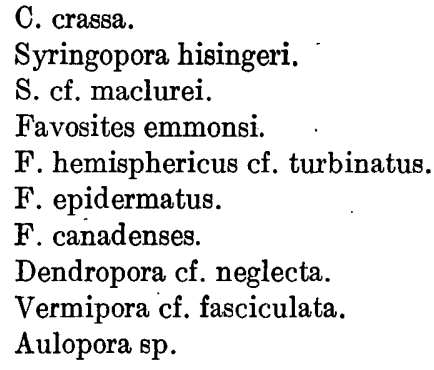

The above list comprises the total fauna found in this bed, with the exception of a few crinoid stems and a couple of small fragments of undetermined brachiopods. Most of these species are such characteristic Onondaga corals that they afford conclusive evidence of the Onondaga age of the limestone. They represent a coral reef which locally seems to have practically excluded other forms of marine life. This coral fauna represents a facies which differs as markedly from that found in the Onondaga shale of the middle Allegheny region as does the Onondaga fauna of the Jeffersonville limestone reef at the Falls of the Ohio. It is the result, doubtless, of bathymetric and other conditions similar to those which produced the coral fauna at the Falls of the Ohio and, like that fauna, it probably represents a portion of the sea bottom which was shallower than that occupied by the Onondaga fauna of the middle Allegheny region.

The fauna of the lower part of the Hancock limestone includes, . according to Bassler, ${ }^{1}$ Leperditia alta, Klodenella clarkei, and other fossils which he considers of Manlius age. Between this fauna and the coral fauna listed above another fauna distinct from both occupies most of the upper part of the Hancock limestone. Schuchert ${ }^{2}$ regards this fauna as representing the New Scotland and Coeymans. Bassler, ${ }^{1}$ recognizing the unusual character of the fauna, seems to regard it as of Coeymans age. The rather unique character of this fauna in the upper part of the Hancock limestone invites a more extended discussion in offering any final opinion as to its age than is here warranted. The most closely related fauna known to me is that in the Armuchee chert at Rome, Ga., but a final correlation must await more complete study, which it is expected will be presented in a future paper. It is sufficient at present to state that whatever its exact correlation may be the fauna just below the coral fauna is very

1 Bassler, R. S., The cement resources of Virginia west of the Blue Ridge: Bull. Virginia Geol. Survey No. 2-A, 1909, p. 273.

2 Am. Jour. Sci., 4th ser., vol. 19, 1905, p. 460. 
different from the Oriskany fauna generally found at the base of the Onondaga to the northeast.

In the lower part of the black shale following the Onondaga Schizobolus concentricus and Lingula ligea occur abundantly at most localities about Big Stone Gap. To these species, which were heretofore the only known representatives of the black shale fauna of this region, my recent collections have added other brachiopods and a rich conodont fauna. These will be listed and described in a later paper on the higher Devonian faunas of the Allegheny region.

The occurrences of the Onondaga fauna at Big Stone Gap and Mendota are the most southerly appearances. of the fauna which I have been able to recognize in Virginia. It is not improbable that the fauna may cross the Tennessee line into Hancock County, although I have failed to find it on the Tennessee side. South of Hancock County in eastern Tennessee the Onondaga fauna is undoubtedly absent, and this time interval is unrepresented in the sediments.

\section{AGE OF THE FAUNA.}

\section{GENERAL CONSIDERATIONS.}

In the preceding pages the stratigraphic relations of the several faunules which occur in the shale and impure limestone bands immediately following the Oriskany sandstone over most of the area have been set forth in detail, and the stratigraphic and paleontologic evidence as to their unity or membership in a common fauna has been given. The age of this fauna as a whole may now be considered.

This general consideration of the whole fauna is important because many individual faunules taken alone do not furnish entirely satisfactory evidence as to their age. In this respect, however, the faunules of this fauna are not peculiar or different from those of various other faunas which might be cited. Illustrations of this fact may be found in the faunules of the Onondaga fauna of New Jersey as listed by Weller. ${ }^{1}$ The faunule $2 \mathrm{~B}$ given by. Weller, for example, taken alone affords no clear evidence of the Onondaga, but when considered in connection with other faunules from the same horizon it leaves no doubt of its Onondaga age.

Examination of the list of species occurring in this fauna shows that the evidence which they afford as to its age is somewhat complex and requires detailed analysis to indicate its exact significance. The fauna includes species that are known in the Oriskany, the Onondaga, the Marcellus, and the Hamilton formations. Before considering the evidence in detail, certain important general factors which enter into the problem of age may be noted. 
It has been shown that the strata holding this fauna occupy a stratigraphic position similar to that of the Onondaga of central New York, being followed above by the Marcellus shale and resting upon the Oriskany sandstone. (See Pl. I.) South of New York, however, the Onondaga formation includes two distinct lithologic elementslimestones and shales, the latter in places including black shales, which approach in appearance the Marcellus shale. In these shales are certain species, like Styliolina fissurella and Bactrites aciculum, which are generally associated in the New York Devonian sections with dark shales. Although these two species are familiar forms in the Marcellus shale, they recur above it in the Devonian whenever shales of the Marcellus type appear in the section. Since these species recur above the Marcellus in the Genesee and Portage it is to be expected that they will probably occur below it wherever shale of the type with which they are always associated appears earlier than the Marcellus in the Allegheny province. In determining the age of shales of this type such species can therefore have little or no weight as evidence of Marcellus age if they are associated with species which are elsewhere known only from beds of Onondaga or earlier age. In most of the faunules these species, which have been recorded as of Marcellus or later age, are associated with species that are not known to occur later than Oriskany or Onondaga time.

So strong is the Oriskany element in the fauna that, if the stratigraphic evidence did not clearly show it to be above the Oriskany sandstone, much paleontologic evidence could be adduced for considering the fauna to-be of Oriskany age: Critical examination of the faunules in connection with the stratigraphic evidence, however, affords satisfactory grounds for correlating the strata and the fauna under consideration with the Onondaga limestone and its fauna.

\section{BIOLOGIC GROUPS.}

A comprehensive view of the intrinsic evidence which the fauna will afford regarding its age can perhaps be best secured by taking up for separate consideration the several biologic groups comprising it in their natural order. The value of the evidence furnished by these different groups will be found to differ, partly because of factors inherent in the faunas themselves, and partly because of fortuitous conditions relating to their collection or condition of preservation.

The trilobites, for instance, furnish the most important evidence given by any single group, not only because they are widely distributed, but because, being the most highly organized invertebrates in the Paleozoic faunas, they were correspondingly sensitive to the changing marine conditions which accompanied the development of successive formations and faunas. The trilobites are therefore the 
most trustworthy index fossils and horizon markers. Their comparatively slight tendency to recur or range beyond their normal horizon is well illustrated in the Chemung of New York State by the recurrent Hamilton fossils, which include many species of Brachiopoda and Pelecypoda, but only one species of the extensive Hamilton trilobite fauna.

The Crinoidea fail to appear in the lists of species here considered, not because the group is unrepresented in the fauna, but because the conditions were generally unfavorable to the preservation of determinable parts.

As might be expected in sediments in which shales are the prevailing element, corals are poorly represented. Only one species is at all common except in the extreme southwestern part of Virginia, where a rich coral fauna containing many index fossils of the typical Onondaga fauna is found. Owing, however, to the small area over which these corals occur they may be omitted altogether from the discussion of the fauna as a whole. If the fauna of this southwestern facies be left out, the evidence furnished by the Cœlenterata on the question of the age may be considered negligible.

The Bryozoa form another group that plays a small rôle in thc fauna for fortuitous reasons. This class of fossils occurs in a fairly satisfactory state of preservation at but two or three localities visited, and no special pains were taken to obtain them at these points.

\section{BRYOZOA.}

The following short list of the Bryozoa, although far from complete, includes the species which were collected and studied:

Cystodictya gilberti (Meek).

Polypora cf. distans (Hall).

P. cf. hexagonalis (Hall).
Coscinium sp. undet.

Fenestella sp. undet.

Hederella sp.

Cystodictya gilberti occurs in the collections from southwestern Virginia and northeastern Pennsylvania and is one of several species indicating the identity of the horizon considered in these widely separated localities. As indicating the age of the fauna its evidence is significant, since it has been recorded from but one Devonian formation-the Onondaga limestone. The other species in the list do not represent specific determinations, but two of them-Polypora cf. distans and $P$. cf. hexagonalis - are closely allied to if not identical with the species with which they are compared, both of which are Onondaga fossils. The evidence of the Bryozoa therefore points toward the Onondaga age of the fauna. 


\section{BRACHIOPODA.}

The species which comprise the brachiopod element of the fauna are shown in the following list:

Lingula cf. ligea Hall.

Pholidops cf. areolata Hall.

Orbiculoidea lodiensis var. media Hall.

O. lodiensis.

Anoplia nucleata.

Strophalosia truncata (Hall).

Productella navicella Hall.

Chonetes hemisphericus Hall.

C. cf. setigerus (Hall).

C. mucronatus Hall.

C. buttsi n. sp.

C. rugosus $\mathrm{n}$. sp.

C. arcuatus Hall.

Atrypa reticularis.

Stropheodonta perplana (Conrad).

S. patersoni Hall.

S. inequistriata (Conrad).

Leptænisca australis n. sp.
Leptæna rhomboidalis (Wilckens).

Schuchertella pandora (Billings).

S. cf. perversa.

Pholidostrophia pennsylvanica n. sp.

Dalmanella lenticularis (Vanuxem).

Rhipidomella vanuxemi (Hall).

Ambocclia umbonata.

A. cf. nana.

Cyrtina hamiltonensis Hall.

Spirifer acuminatus (Conrad).

S. varicosus Hall.

Reticularia cf. fimbriata (Conrad).

Pentagonia unisulcata (Conrad).

Anoplotheca acutiplicata (Conrad).

A. camilla.

Meristella nasuta (Conrad).

Nucleospira concinna Hall.

Cranæna cf. romingeri Hall.

The testimony of the brachiopods as to the age of the fauna can be brought out in one way by comparing the above list with lists of brachiopods from four of the Middle and Lower Devonian formations at a representative Devonian locality in eastern New York. Grabau's lists ${ }^{1}$ of the several faunas of the Devonian of the Schoharie Valley give the faunas of the Devonian formations from Marcellus to Oriskany, which, though incomplete, are fairly representative of these several faunas. Numerical comparison of the identical brachiopod species named in these several lists with those in the list above should indicate the fauna with which its affinity is strongest.

Comparison with Grabau's list of "fossils of the Onondaga limestone of the Schoharie region" 2 shows that $33 \frac{1}{3}$ per cent of the brachiopods in the fauna under discussion, or about 50 per cent of the brachiopods in Grabau's list, are common to both lists. In the Schoharie list, as in the one above, there are some species which occur more frequently in the Hamilton than in the Onondaga. Cyrtina hamiltonensis is a representative of this class.

Similar comparison with the brachiopods in Grabau's list from the Hamilton formation ${ }^{3}$ in the Schoharie region shows only six species common to the two lists-about 22 per cent of the Allegheny species and less than 25 per cent of Grabau's species.

1 Bull. New York State Mus. Nat. Hist. No. 92, 1906, pp. 317-332.

2 Idem, p. 328.

3 Idem, p. 329. 
Comparison with the Marcellus species of brachiopods in the Schoharie Valley as recorded by Grabau reveals a still greater degree of dissimilarity, only two species, or $6 \frac{1}{2}$ per cent, being common to the two lists.

The Oriskany fauna of the Schoharie region as reported by Grabau includes no species common to the two faunas.

The foregoing comparison of the brachiopod element of this fauna with that of four Lower and Middle Devonian formations in the Schoharie region shows very clearly that numerically the relationship to the Onondaga fauna is decidedly the strongest.

Although this comparison of the brachiopods of the fauna with the representative lists of the Onondaga and Hamilton brachiopods in the Schoharie Valley is strongly suggestive of the Onondaga age of the fauna, it will be more convincing to examine in detail the horizon values of the several species composing the list. The data indicating the known range of the several species has been compiled from Schuchert, ${ }^{1}$ and supplemented by examination of many more recent special papers.

Exclusive of new and doubtfully determined species the list on page 56 contains twenty-four species of brachiopods which are specifically determined. Nine of these are recorded from the Marcellus, Hamilton, and other later horizons, but not from the Onondaga or earlier horizons. Eleven are common to Onondaga and later faunas. Four are known from Oriskany and Onondaga faunas, but from no later horizon. Six are recorded from the Onondaga alone. Not a single species is limited in range to the Hamilton fauna. Briefly summarized, this analysis shows that the list contains seventeen species, which afford no precise evidence as to the horizon represented, not a single characteristic species of the Hamilton, and six species which elsewhere are recorded only from the Onondaga fauna.

The seventeen species treated in this analysis as having no precise value as horizon markers include two species, Spirifer acuminatus and Pentagonia unisulcata, which have generally been regarded as characteristic Onondaga species. Their occurrence in the Hamilton, however, is so very rare that they may be considered characteristic and normal representatives of the Onondaga. in a fauna of this type. Hence it appears that the list contains no guide fossils of the Hamilton and that about one-third of it consists of characteristic Onondaga fossils.

I Schuchert, Charles, Synopsis of American fossil Brachiopoda: Bull. U. S. Geol. Survey No. 87, 1897. 


\section{PELECYPODA.}

The pelecypod element of the fauna is represented by the following seventeen species:

Grammysia sp.

Palæoneilo cf: constricta.

Buchiola halli.

Nucula cf. corbuliformis

Nuculites modulatus n. sp.

Lunulicardium curtum.

Pterochænia fragilis.

Pterinea sp. undet.

Conocardium cf. cuneus var. nasutum.

\author{
Actinopteria muricata. \\ Aviculopecten equilatera. \\ Modiomorpha subalata. \\ Cypricardinia indenta. \\ Leiopteria lævis. \\ Panenka cf. dichotoma. \\ Panenka cf. multiradiata. \\ Panenka alternata.
}

Examination of the observed range of the fossils shows that only four are recorded as Onondaga species, the other thirteen all being known from either the Marcellus or the Hamilton. Taken alone the evidence of this group of fossils numerically would seem to point to the Marcellus age of the fauna-in the opposite direction from that of the preceding group. It includes, however, one species, Panenka alternata, which is unknown above the Onondaga. In explanation of the apparent conflict between the evidence. furnished by the Pelecypoda, on the one side, and by the Brachiopoda, Trilobita, and other groups, on the other, the fact may be cited that only a comparatively small pelecypod fauna is known from the typical or limestone facies of the Onondaga. As an example of the relative abundance of the Pelecypoda in the Hamilton and Onondaga formations, or at least of the relative amount of recorded information at an average locality, attention may be directed again to Grabau's lists of the Hamilton and Onondaga fossils in the Schoharie Valley. ${ }^{1}$ The Hamilton list includes seventy-five species of Pelecypoda, whereas the Onondaga list includes but one. Hall undertook to describe "all the well-known and determined species of Lamellibranchiate shells from the Upper Helderberg (Oriondaga), Hamilton; Portage, and Chemung groups"; ${ }^{2}$ but this work describes only a very small percentage of Onondaga Pelecypoda and a very large percentage of Hamilton species. The relative abundance of Pelecypoda in the lists of fossils obtained from these two formations seems to depend largely on the fact that one is a nearly pure limestone and the other is usually some type of shale. Lists of fossils from other Paleozoic horizons appear to bear out the observation that the pelecypods were most abundant under conditions favorable to the accumulation . of shales and sandstone and least abundant in clear waters. In an Onondaga facies similar to the usual Hamilton facies as great a percentage of Pelecypoda as of Brachiopoda common to both horizons

1 Bull. New York State Mus. No. 92, 1906, pp. 328-331.

2 Paleontology of New York, vol. 5, pts. 1 and 2, 1885, p. vii. 
might reasonably be expected in any given region. Most of these mollusks, however, would appear in recorded lists as Hamilton species, because the almost uniformly calcareous Onondaga rocks which have furnished the recorded fauna of the Onondaga represent a habitat that was comparatively unfavorable for these mud or sand-bottom loving creatures. In the sediments and fauna under consideration the rocks represent a facies which approaches much more closely to the Hamilton than to the usual Onondaga type, and it is natural that the Pelecypoda should have an apparent Hamilton aspect. They appear here for the first time in pre-Hamilton rocks because, for the first time, conditions were favorable to their existence.

Although the pelecypod fauna is deficient in positive elements indicating its Onondaga age it affords negative evidence of its preHamilton age in its entire lack of those Pelecypoda which are generally considered to belong among the distinctly characteristic Hamilton species. Some of the characteristic Hamilton shells which are conspicuously absent are Modiomorpha myteloides, Cypricardella bellistriatus, and Pterinea flabella. The absence of these common characteristic Hamilton pelecypods is as significant of the preHamilton age of the fauna as is the entire absence of Tropidoleptus carinatus from the brachiopod fauna.

\section{GASTROPODA AND PTEROPODA.}

The Gastropoda and the Pteropoda contribute, respectively, fourtoen and eleven species to the fauna, but the evidence they furnish concerning the age of the fauna is not proportionate to the number of species represented. This evidence is not sufficiently definite to require detailed consideration here. The gastropod list contains Bellerophon pelops, a fossil not recorded above the Onondaga limestone in the New York section. The pteropod group includes the species Tentaculites scalariformis, which is also an Onondaga species. Associated with these species, however, are others that are better known at Hamilton than at Onondaga horizons. Hence the evidence afforded by these groups, considered independently, is indecisive.

\section{CEPHALOPODA AND CONODONTS.}

The few species represented by the cephalopods and the conodonts in this fauna are also inconclusive and may be passed without discussion. 


\section{OSTRACODA.}

The fossils collected include many undetermined Ostracoda and probably several new species, which are necessarily omitted from the fauna as listed in this paper. The others are as follows:

Leperditia? cf. subrotunda.

Bollia ungula.

B. obesa.

Bythocypris favulosa.

Octonaria stigmata.

Ulrichia conradi.

Craterellina n. gen. n. sp. (MS.). ${ }^{1}$

In order to ascertain what light this group of fossils will throw on the age of the whole fauna, inquiry may be made as to their recorded range in regions outside the Allegheny province. One species, Bythocypris favulosa, has not been reported subsequent to its discovery at New Bloomfield by Claypole and may be omitted from consideration. Of the remaining six species one, Ulrichia conradi, has been recorded from the Hamilton and the other five from the Onondaga. One of them, Bollia ungula, has been reported also from the lower Oriskany by Ulrich and Bassler. ${ }^{1}$ Thus we find that more than 70 per cent of the species known in other regions are Onondaga. Whatever weight of evidence the one Hamilton species might carry for a post-Onondaga age is more than offset by the presence of the one Oriskany species and of a genus not hitherto recorded from any horizon later than the Oriskany. It is noteworthy that the two species recorded from the Marcellus in western New York ${ }^{2}$ are lacking and that the list includes no ostracode species known to occur in the Marcellus shale.

Perhaps no more striking evidence of the early Devonian or preMarcellus aspect of the ostracode fauna can be cited here than the fact that an expert student of this group was strongly inclined, after a preliminary examination of this part of the fauna alone, to regard it as representing an Oriskany horizon. One of the ostracode species suggesting an early Devonian horizon is a representative of the remarkable new genus Craterellina (MS.) described by Ulrich and Bassler from the lower Oriskany ${ }^{1}$ and unknown elsewhere from beds later than the Oriskany.

\section{TRILOBITA.}

The trilobites listed in this paper include a considerable number of species hitherto unknown south of New York State. These furnish most important evidence as to age, for with comparatively few exceptions Devonian trilobites do not cross formation boundaries in their range. From the Onondaga limestone of New York, Hall and Clarke have recognized forty-nine species of trilobites, of which only one occurs

1 Ulrich, E. O., and Bassler, R. S., Rept. Maryland Geol. Survey (in press).

2 Clarke, J. M., Bull. New York State Mus. No. 49, 1901, p. 131. Wood, Elvira, idem, pp. 142-173. 
in the Helderberg limestone, three in the Oriskany sandstone, and only a single characteristic species ranges upward into the Hamilton. ${ }^{1}$ That the results of more recent collections have not altered materially these conclusions is shown by examination and comparison of Grabau's lists of the trilobites in the Onondaga and the Hamilton formations of the Schoharie region. ${ }^{2}$ Inspection of these lists shows not a single species common to the two. From the Marcellus and the "Agoniatites limestone" no trilobites are recorded by Grabau. A somewhat similar result is obtained on comparing the trilobites recorded by Van Ingen ${ }^{3}$ from the Oriskany at Rondout and Glenerie, N. Y., with the New York trilobite fauna of the Onondaga as given by Hall and Clarke; only one species is common to the two lists. These citations of some of the more essential recorded data regarding the range of the Onondaga trilobites afford a basis from which to judge the significance of the large percentage of Onondaga species of the trilobites of the fauna under consideration.

The following list includes the species which have been recognized in the fauna:

\footnotetext{
Acidaspis callicera.

Phæthonides gemmæus.

Lichas (Arges) contusus.

Phacops cristata.

P. cristata var. pipa.

P. rana.

Conolichas hispidus?
}

\author{
Cyphaspis cf. stephanophora. \\ Odontocephalus ægeria. \\ O. selenurus. \\ Dalmanites (Coronura) aspectans? \\ D. sp. undet. \\ D. (Cryphæus) cf. boothi var. calliteles.
}

The above list of thirteen species contains three trilobites known in the Hamilton fauna. One of these, Phrthonides gemmæus, is the species which Hall and Clarke record as common to the Onondaga and Hamilton faunas in New York. The specific identity of another, Dalmanites (Cryphæus) cf. boothi var. calliteles, is not definitely determined; if it is the species with which comparison is made, it represents its first reported occurrence at a horizon earlier than the Hamilton. The third species, Phacops rana, is one of the very few Devonian trilobites having a wide range. It has its maximum development in the Hamilton but is known to range as high as the Chemung. It has been doubtfully reported from the Onondaga limestone in New York. ${ }^{4}$ In view of its great range its occurrence here is without special significance in reference to the age of the fauna. All of the other ten species are characteristic Onondaga trilobites. One of these, Odontocephalus xgeria, which is unknown above or below the Onondaga horizon, is one of the most widely distributed species in the fauna. The important and decisive fact which examination of the 
trilobites of the fauna discloses is that all the definitely determined species, with the exception of two which have been previously recorded from both the Onondaga and the Hamilton, are characteristic Onondaga species. This evidence of the Onondaga age of the fauna appears to be complete and conclusive.

\section{CONCLUSION.}

The evidence relating to the age of the fauna is both stratigraphic and paleontologic. It has been shown (pp. 11-19) that the calcareous shales holding this fauna are in most places underlain in the sections by the Orisiskany sandstone and are everywhere overlain by the dark fissile and comparatively barren shales of the Marcellus. These two limiting formations exhibit in general essentially the same lithologic characters throughout New York, Pennsylvania, Maryland, West Virginia, and most of Virginia. Both are, however, much thicker in the southern region than in the type region of the Onondaga limestone in New York. In the Helderberg Mountain region the Onondaga and the Hamilton faunas are separated by 300 feet of comparatively barren dark Marcellus shale and in western New York by shale of about half this thickness, whereas in Pennsylvania and in areas farther south these shales in many places haveoa thickness of more than 500 feet.

Though the succession from the Onondaga fauna to the Marcellus shale and fauna above is uniform throughout the Allegheny region, as it is in New York, the succession at the base of the fauna is not. everywhere precisely the same. In most of the territory the Onondaga rests upon the Oriskany, but in some of the Pennsylvania sections it immediately overlies beds representing the Esopus shale and possibly the Schoharie as well. In respect to its underlying formation, however, the Onondaga shows less variation in the Allegheny region than in New York where, in different areas, it is found to follow the Manlius, Oriskany, Esopus, and Schoharie. Thus we find that this fauna occupies in the Allegheny region the same relative position in the succession of faunas as the Onondaga formation does in the standard sections of New York. The stratigraphic evidence, therefore, points to the Onondaga age of the fauna.

All of the Devonian faunas are composed of indigenous and exotic species. Each fauna is distinguished from its predecessor by a greater or less number of the latter class-immigrants from some alien region. This fauna contains a number of indigenous species which have been passed on to it from the Oriskany fauna. Many of these indigenous species are found in the Hamilton also. Some of them, like Chonetes mucronatus, range from the Oriskany, where they first appear in eastern America, into the Hamilton. That the fauna does not represent a late phase of the Oriskany is indicated by the presence of 
a large percentage of exotic species which have been found elsewhere only in the Onondaga formation. On the other hand, the entire absence from the fauna of any of the species which can be regarded as exotic Hamilton species affords decisive evidence against the alternative hypothesis of early or prenuncial Hamilton age. Such species as Tropidoleptus carinatus, Spirifer audaculus, Modiomorpha myteloides, and Cypricardella bellistriatus which marked the appearance of the Hamilton fauna in eastern America are conspicuously absent from this fauna, which in this respect shows a striking contrast. with the limestone faunas described by Clarke and Wood $^{1}$ from the

- Marcellus shale of New York. Three of the above-named species are recorded in their faunas and plainly indicate a later fauna than the one under discussion here.

Both the faunal and the stratigraphic evidence, therefore, seem fully to warrant the correlation of the fauna with the Onondaga.

\section{PALEOGEOGRAPHIC SIGNIFICANCE OF THE FAUNA.}

The faunal and stratigraphic evidence which has been presented calls for a distinct modification of the current conception of the extent of the Onondaga sea in the eastern part of the United States. It is a noteworthy fact that nearly all the contributions to the knowledge of the Onondaga fauna have dealt with a nearly pure limestone fauna. If one were to seek a comprehensive idea of the character of the Onondaga sea and its sediments from the published descriptions of the fauna and the limestones holding it, he would get the conception of a sea in which only limestones were deposited. To anyone who admits that the factors controlling marine sedimentation were essentially the same in Paleozoic and in recent times, a Devonian sea in which only calcareous sediments accumulated is a manifest absurdity. We know of no continental or other seas in which there are not a variety of types of sediment accumulating simultaneously. Papers which have undertaken to deal with this fauna in a large way and weld its evidence into the new science of paleogeography have naturally been influenced by the fact that the only faunas from the Onondaga sea described except that of the Kanouse sandstone ("Newfoundland grit") of New Jersey ${ }^{2}$ were limestone faunas. Translated into the form of a paleogeographic map this class of evidence taken alone gives us a sea whose outlines ${ }^{\theta}$ inclose only limestone sediments.

In order to ascertain to what extent recorded evidence will permit the delineation of the shore line of the Onondaga sea within the limits

1 Clarke, J. M., Marcellus limestones of central and western New York and their fauna: Bull. New York State Mus. No. 49, 1901, pp. 115-138. Wood, Elvira, Marcellus limestone of Lancaster, Erie County, N. Y.: Idem, pp. 139-182.

. '2Weller, Stuart, Paleontology of New Jersey, vol. 3, 1903, p. 104. 
of the Eastern States so that it will appear consistent and rational with reference to the character of the known deposits of that sea, we may consider briefly the principal sources of its sediments. The comparatively thin mass of sediments which accumulated during the whole of the Devonian in the Central States-it was less than 200 feet thick in the Ohio Valley-affords satisfactory evidence that the land area adjacent to the Devonian sea on the west had slight relief and furnished comparatively little sediment at any time during the Devanian. On the east side of the Devonian sea, however, physiographic conditions were very different.

The greater part of the Allegheny province was occupied during the Devonian by a broad arm of the sea known as the Appalachian Gulf. Along the eastern border of this sea was deposited the 5,000 to 10,000 feet of Devonian sediments found in the Allegheny region. The chief source of this clastic material has been shown to be a land area known as the highlands of Appalachia, which lay immediately southeast of the Allegheny region. This old land area furnished to the interior Devonian sea of the Appalachian region, between the beginning of Middle Devonian time and the close of the Devonian, a mass of terrigneous sediments which, if restored upon a sea-level plain of Appalachia, "would constitute a mountain range closely resembling in height, extent, and mass the Sierra Nevada of California."

The paleontologic and stratigraphic data which have been presented in preceding pages show that Onondaga sediments are present in the Allegheny region and that they are mainly of noncalcareous or clastic type, as might have been expected from theoretical considerations. The discovery of an Onondaga fauna in the Allegheny region, in the series of drab or dark shales and thin interbedded argillaceóus limestones that have been described, thus very materially supplements the hitherto one-sided character of the available data relating to the nature of the fauna and sediments of the Onondaga sea. The sediments holding this fauna are of a character that might naturally be formed on some portion of the Onondaga sea floor, as is indicated by analogy with the processes of sedimentation now in operation in the largest continental seas. We may now consider the bearing of the data which have been cited on the modification of the current conception of the eastern shore line of the Onondaga sea in the eastern United States.

The Onondaga formation extends not far south of Delaware River, according to most of the papers dealing with the stratigraphy of of the Devonian in the Allegheny region, thus giving it a north-south extension of scarcely 200 miles. The evidence which has been presented, however, indicates that the southerly extension of the Onondaga fauna is quite comparable in distance with its westerly extension. 
The field studies of the writer have shown that the Onondaga fauna in the Allegheny region extends far south of the area in which nearly pure limestones were deposited during Onondaga time, into a region where shale-forming sediments partly or completely dominated those of calcareous type. This fauna has been found in nearly all the sections studied from New York to Tennessee.

The direct bearing of these new data on the paleogeography of Onondaga time is obvious. They indicate the extension of the eastern shore line of the Onondaga sea in a southwesterly direction from southeastern New York to the east of the Allegheny region instead of far to the west of it, as previously drawn in paleogeographic maps, across the States of Ohio, Indiana, and Kentucky. In the light of this new evidence it appeairs that the eastern shore line of the Onondaga sea trended southwestward across north-central New Jersey and southeastern Pennsylvania. It probably traversed the States of Maryland and Virginia near the present axis of the Blue Ridge. From southwestern Virginia this shore line appears to have trended westward not far from the Kentucky-Tennessee line as far as the valley of Tennessee River, where it resumed its southerly trend.

$20495^{\circ}-$ Bull. 508-12-5 


\title{
DESCRIPTION OF THE FAUNA. ${ }^{1}$
}

\section{COLLNTERATA. ${ }^{2}$}

\section{Genus ZAPHRENTIS Rafinesque.}

Zaphreñtis ef. SIMPlex Hall.

\author{
Plate II, figure 1.
}

1843. Cf. Stromboaes simplex. Hall, Geology New York, Survey Fourth Geol. Dist., 1843, p. 209, fig. 6.

1876. Cf. Zaphrentis simplex. Hall, Illus. Dev. Fos., 1876, pl. 21, figs. 5-11.

A few imperfect shale molds and casts of a coral closely resembling and probably identical with this species occur in the collection. The best preserved of these, here figured, exhibits the following features:

Corallum. smooth, gently and regularly expanding from the base; deflected near the base; calyx deep.

Distribution.-New Bloomfield, Pa., and Clifton Forge, Va.

\section{Genus PLEURODICTYUM Goldfuss.}

Pleurodictyum sp. undet.

Plate II, figure 3.

The species of poriferous coral here figured has been found at only two widely separated points-Perry County, Pa., and the James River valley, Va. The occurrence of this peculiar coral at about the same level above the Oriskany at localities so far apart as these has perhaps more stratigraphic than tectological interest, as the material, although indicating clearly the same species at the two localities, hardly justifies reference to any described species. It is comparable with the species illustrated by Davis ${ }^{3}$ under the name of Procteria papillosa Davis, but is believed to belong to Pleurodictyum.

The specimens are contained in a hard drab shale, which preserves none of the original corallite material, showing only shale molds of the individual corallites and of their numerous mural pores, their size and relations.

1 No attempt has been made to give complete synonymy except for the Pelecypoda. In other groups the citation of the original description and one or more papers in which figures have been published is given for the convenience of the reader. For additional synonymy reference may be made to Bull. U.S. Geol. Survey Nos. 63, 87, and 173, and to Miller's North American geology and paleontology.

${ }^{2}$ A rich coral fauna of Onondage age was discovered in sou thwestern Virginia after the plates and descriptions of species for this paper had been completed. This fauna comprised about 20 additional species, which will be found lister on p. 52 .

${ }^{3}$ Kentucky fossil corals, pt. 2, 1885, pl. 41, figs. 15-21. 
The best preserved specimen shows a corallum 6 millimeters in diameter composed of six corallites. Base nearly flat; corallites connected by numerous intermural pores. Most of the lateral pore fillings appear as-spines in the specimens. The figured specimen shows only four of the original six corallites which belonged to it.

Distribution.-New Bloomfield, Pa., and Clifton Forge, Va.

\section{Genus CYSTIPHYLLUM Lonsdale.}

Cystiphyllum americanum Edwards and Haime.

Plate II, figure 2.

1843. Cystiphyllum cylindricum Lonsdale. Hall, Geology New York, Survey Fourth Geol. Dist., 1843, p. 209, figs. 1, 2.

18,51. Cystiphyllum Americanum. Edwards and Haime, Polyp. Foss. Terr. Pal., 1.851, p. 464 , pl. 13, fig. 4 .

1876. Cystiphyllum americanum. Rominger, Geol. Survey Michigan, 1876; vol. 3, pt. 2, p. 133, pl. 50, figs. 1, 2, and 4 .

This is one of the most abundant species in the coral fauna of southwestern Virginia. It is unknown in the shale and argillaceous beds which generally represent the Onondaga in the Allegheny region.

Distribution.-Big Stone Gap, Va.

\section{Genus BLOTHROPHYLLUM Billings.}

\section{Blothrophyllum decorticatum Billings.}

Plate II, figure 4.

1859. Blothrophyllum decorticatum. Billings, Canada Jour., 1859, vol. 4, p. 130.

1876. Blothrophyllum decorticatum. Rominger, Geol. Survey Michigan, 1876, vol. 3, pt. 2, p. 113, pl. 41, figs. 1 and 2.

This characteristic Onondaga coral is common in an excellent state of preservation in the coral reef fauna of southwestern Virginia.

Distribution.-Wild Cat Creek and Big Stone Gap, Wise County, Va.

\section{ECHINODERMATA.}

The presence of crinoids in this fauna is attested by a few crinoid stems and some deeply notched plates; but even these are comparatively rare and no determinable remains of the Echinodermata have been found.

\section{VERMES. \\ Genus POLYGNathus Hinde.}

Polygnathus sp. undet.

Plate II, figure 5.

Base slightly arched; teeth nearly uniform in size, 10 or more in number, conical, and acutely pointed. The base has a length of about 3 millimeters and the teeth a height of 0.5 millimeter. 
The only specimen observed is incomplete, a portion of the base and the basal portion of some of the teeth having been broken away.

Distribution.-In black blocky shale at Tonoloway, Md.

\section{BRYOZOA.}

\section{Genus HEDERELLA Hall.}

Hederella sp. undet.

This genus is represented by an undetermined delicate filiform species which occurs in the black shale.

Distribution.-East of Cumberland, Md.

\section{Genus CYSTODICTYA Ulrich.}

Cystodictya gilberti (Meek).

1871. Ptilodictya (Stictopora) Gilberti. Meek, Proc. Acad. Nat. Sci. Philadelphia, 1871, p. 63.

1873. Ptilodictya (Stictopora) Gilberti. Meek, Paleontology of Ohio, vol. 1, 1873, p. 194, pl. 18, figs. 1 a-c.

The specimens representing this species display prominently the arching transverse undulations of growth and the radiating longitudinal lines of the mesotheca on most individuals. The cells of the fronds are less perfectly preserved.

Distribution.-Schuylkill Haven, Pa.

\section{Genus CoscINiUM Keyserling.}

Coscrnium sp. undet.

An undetermined species of Coscinium in the collection resembles somewhat C. striatum, but has larger meshes than that species.

Distribution.-Schuylkill Haven, Pa.

\section{Genus FENESTELLA Lonsdale.}

Fenestella sp. undet.

A number of poorly preserved specimens comparable with $F$. parallella are included in the collection.

Distribution.-Schuylkill Haven, Pa.

\section{Genus POLYPORA McCoy.}

Polypora cf. distans (Hall).

1883. Cf. Fenestella distans. Hall, Trans. Albany Inst., vol. 10, 1883, p. 166 (abstract, 1.881, p. 23).

1883. Cf. Fenestella (Polypora) distans. Hall, Rept. State Geologist New York for 1882, 1883, pl. 30, figs. 2-3, ? 6-10, 15, 16.

The collections contain one specimen representing the noncelluliferous face of a frond, which probably belongs to this species. 
Polypora cf. hexagonalis (Hall).

1883. Cf. Fenestella hexagonalis. Hall, Trans. Albany Inst., vol. 10, 1883, p. 169 (abstract, 1.881, p. 27).

1883. Cf. Fenestella (Polypora) hexagonalis. Hall, Rept. State Geologist New York for 1882, 1883, pl. 31, figs. 14-20.

The specimens provisionally referred to this species agree with $P$. hexagonalis in the superficial characters, which alone can be examined in the material at hand.

Distribution.-Schuylkill Haven, Pa.

\section{BRACHIOPODA.}

Genus IINGULA Brugière.

Lingula cf. Ligea (Hall).

Plate II, figure 6.

1860. Cf. Lingula ligea. Hall, Thirteenth Rept. New York State Cab. Nat. Hist., 1860, p. 76.

1867. Cf. Lingula ligea. Hall, Nat. Hist. New York, Paleontology, vol. 4, 1867, p. 7, pl. 1, fig. 2.

Shell subelliptical, sides parallel, posterior margin gently rounded from the obtuse or slightly pointed beak, anterior margin broadly rounded. Surface covered with fine concentric striæ. The specimens studied show no indication of the obsolescent radiating striæ said by Hall to characterize L. ligea.

Distribution.-Abundant in dark shale 2 miles west of Canoe Creek, Blair County, Pa. Less abundant at Ridgeville, W. Va.

\section{Genus ORBICULOIDEA D'Orbigny.}

Orbiculoidea Lodiensis var. media (Hall).

Plate II, figures 9, 10, 11.

1863. Discina media. Hall, Sixteenth Rept. New York State Cab. Nat. Hist., 1863, p. 27.

1867. Discina media. Hall, Nat. Hist. New York, Paleontology, vol. 4, 1867, p. 20, pl. 2, figs. 25-29.

Shell subcircular or broadly elliptical. Dorsal valve moderately convex normally but commonly much depressed by pressure. Apex pointed and excentric, placed one-third to one-fourth the length of the shell from the posterior margin. Interior of the valve marked, by a weak linear septal ridge about a millimeter in length, just anterior to the apex and in the longitudinal axis of the shell. Ventral valve slightly convex or nearly flat. Foramen making an elevated ridgelike platform in the interior of valve. Surface of shell marked by fine regular striæ with intermediate spaces about twice their width.

Distribution.-Abundant at most localities from northeastern Pennsylvania to northern Virginia. 


\section{Orbiculoidea cf. lodiensis (Vanuxem).}

1842. Orbicula lodensis. Vanuxem. Geol. New York, Survey Third Geol. Dist., 1842, pi 168 , fig. 1 .

At one or two localities a shell has been collected which is similar to the preceding but with finer, less elevated and closer spaced concentric striæ. The finer striæ and very faintly marked fine radiating lines seem to identify it with this species.

Distribution.-Mountain Grove, Va.

\section{Genus PHOLIDOPS Hall.}

\section{Pholmops cf. areolata (Hall).}

Plate II, figures 7,8 .

1863. Cf. Pholidops areolata. Hall, Sixteenth Rept. New York State Cab. Nat. Hist. 1863, p. 31.

1867. Cf. Pholidops areolata. Hall, Nat. Hist. New York, Paleontology, vol. 4, 1867, p. 31 , pl. 3 , figs. 4,5 .

A minute Pholidops closely related to if not identical with $P$. areolata, is frequently met with in this fauna.

The shell is subovate, the width of the posterior portion being slightly greater than that of the anterior. Surface marked by strongly lamellose concentric striæ. The mold of the interior of the ventral valve shows a strongly impressed muscular scar, deepest anteriorly, somewhat resembling the impression of a bovine hoof.

Distribution.-Blair County, Pa.; Ridgeville, W. Va.; Clifton Forge; Mendota, and Little Moccasin Gap, Va.

\section{Genus CHONETES Fischer de Waldheim.}

\section{Chonetes hemisphericus (Hall).}

Plate III, figures 15, 16.

1857. Chonetes hemispherica. Hall, Tenth Rept. New York State Cab. Nat. Hist., 1857, p. 116, figs. 1-3.

Shell hemispherical with auriculate hinge line. Surface covered by regular rounded striæ. Some of these bifurcate toward the middle of the shell, and a few arise as intercalated striæ, but many continue from the beaks to the margin as simple striæ. The striæ number from 40 to 65 in specimens studied. Extremely fine concentric striæ may be observed on some specimens. No spines are preserved in the specimens studied. This species has been recognized at but one locality, where it is abundant. The highly arched ventral valve, auriculate hinge line, and generally simple radiating striæ suffice to establish its identity.

Distribution.-Schuylkill Haven, Pa. 
Сhoneteis cf. Setigerus (Hall).

Plate III, figure 17.

1843. (f. Strophomena setigera. Hall, Geol. New York, Survey Fourth Geol. Dist., 1843 , p. 180, fig. 2 ; p. 222 , fig. 3.

The specimens here referred to are rather larger than ordinary specimens of Chonetes setigerus. The rentral valve is conspicuously arched and is marked by about sixty rounded radiating striæ, most of which arise through bifurcation at various distances from the beak. The specimen figured indicates nearly vertical spines, the two on the right being deflected by pressure. The spine on left of beak indicates their vertical habit, which shows no tendency to the.primary lateral deflection generally seen in $C$. setigerus.

Distribution.-Selinsgrove Junction, $\mathrm{Pa}$ :

\section{Chonetes mucronatus Hall.}

Plate III, figures $13,14$.

1843. Strophomena mucronata. Hall (non Conrad), Geology of New York, Survey Fourth Geol. Dist., 1843, p. 180, fig. 3.

Shell moderately convex. Surface of each valve covered by twelve to twenty-four coarse plications, most of which are simple. In some specimens a few of the plications bifurcate near the margin. Less than half the plications originate in the umbonal region or at the beak, the others starting at the hinge line on either side of the beak. Very fine concentric striæ may be seen on exceptionally preserved shells. Two extremely slender spines originate from the hinge line of the ventral valve and extend outward parallel with it and with each other so as to give often the appearance of a single spine, appearing to be the mucronate extension of the hinge line. In some specimens the length of one of these spines greatly exceeds the width of the valves. This species is clearly identical with the Marcellus species originally described by Hall as Chonetes mucronatus, but in the character of the spines and in the absence of a nonplicated area at the cardinal angles it differs from C. Taticosta of the Onondaga which Hall ${ }^{1}$ identified with $C$. mucronatus. The spines of $C$. laticosta are much shorter and lack the almost complete parallelism with the hinge line seen in $C$. mucronatus.

Distribution.-Chonetes mucronatus is one of the most abundant species in the fauna. It is found nearly everywhere from New York to southwestern Virginia. 


\section{Chonetes Buttsi n. $\mathrm{sp}$.}

Plate IV, figures 1-4.

Shell semicircular in outline, the ventral valve depressed convex, dorsal valve nearly flat. Surface covered by seventy-five to one hundred fine regular striæ increasing by bifurcation and intercalation. Well-preserved specimens show very fine concentric striæ crossing these. Two or three acicular spines on each side of the beak of the ventral valve extend nearly at right angles to the hinge line. These are remarkable for their extreme and uniform slenderness from base to tip. The outermost pair arise just inside the points of the hinge line and are inclined slightly outward for a fraction of a millimeter at the base; then they assume the vertical direction. The spines generally have a length equal to or greater than that of the shell. One specimen representing a pathologic individual is interesting as showing the development of the spines under unusual conditions. The shell near the left cardinal angle is absent as a result either of failure to develop normally or of having been broken away. This results in nearly half the hinge line on that side of the shell being absent. The three spines belonging on this side of the shell are present, however, and have developed from the margin of the shell, which fortuitously represents the outer portion of the hinge line. The form nearest allied to this species is Chonetes setigerus, the main points of difference being in the number of striæ, size, convexity and length of spines. C.buttsi has about double the number of striæ of $C$. setigerus and averages about twice its size. The spines of the latter species are also notably shorter than those of the former, and $C$. buttsi is a much more depressed form than $C$. setigerus.

Dedicated to Mr. Charles Butts, of the United States Geological Survey.

Distribution.-This species occurs abundantly 2 miles west of Canoe Creek, Blair County, Pa. It has not been found elsewhere.

\section{Chonetes Rugosus n. $\mathrm{sp}$.}

Plate IV, figures 5-7.

Shell medium size, transverse in outline, slightly convex on the ventral side. Surface marked by fine closely placed striæ numbering about one hundred. All of the striæ bifurcate before reaching the margin, some of them repeatedly. Six to ten concentric undulations or corrugations cross the striæ. These are strongest in the median and anterior portion of the shell and die out toward the anterior margin. The hinge line is mucronate, the extremities extending considerably beyond the sides of the shell. A strong riblike process or pseudo hinge line arises from the hinge line about midway between the beak and the extremity of the mucronate extension, curves very gently upward from the hinge line, and extends to or beyond its 
extremities. A peculiar nonstriated earlike process is subtended between the hinge line proper and the pseudo hinge line. This, on the inner surface, is marked by a series of closely spaced diagonal denticulations. Dorsal valve and internal characters are unknown.

The peculiar denticulated earlike expansion posterior to the hinge line distinguishes this from any other Chonetes. A single specimen doubtfully referred to this species shows two short outwardly directed spines on each side of the beak. Ordinary spines have not been observed on any other specimens referred to this species.

Distribution.-In soft drab shales at Cumberland, Md.

Chonetes, (Eodevonaria) arcuatus Hall.

Plate III, figures 9-12.

1857. Chonetes arcuata. Hall, Tenth Rept. New York State Cab. Nat. Hist., 1857, p. 116.

1867. Chonetes arcuata. Hall, Nat. Hist. New York, Paleontology, vol. 4, 1867, p. 119, pl. 20, figs. 7 a-f.

Shell semielliptical or semicircular and decidedly gibbous. Surface covered with very fine rounded striæ which increase by bifurcation and intercalation. These number one hundred or more on mature individuals. Very fine concentric striæ cross the radiating striæ. The ventral valve has a well-developed area inclined at about $35^{\circ}$ to the plane of the valves. The inner margin of the area is bordered by fifteen to twenty strong crenulations on each side of the beak. A low rounded septum extends from one-third to one-half the distance from the beak to the front of the shell. Well-marked muscular scars lie on either side of the septum, as shown in the figure. The specimens studied vary in size with respect to width from 16 to 30 millimeters.

Distribution.-Abundant at Mendota and Little Moccasin Gap, Va.; not observed farther north.

\section{Genus ANOPLIA Hall and Clarke.}

\section{Anoplia nucleata Hall.}

Plate V, figures 8-11.

1857. Leptæna nucleata. Hall, Tenth Rept. New York State Cab. Nat. Hist., 1857, p. 47.

1859. Leptæna? nucleata. Hall, Nat. Hist. New York, Paleontology, vol. 3, 1859, p. 419 , pl. 94, fig. 1.

Shell small, concavo-convex, and strongly arched. Surface without striæ or plications. Interior of both valves strongly pustulose. Ventral valve very gibbous in the umbonal and median region, beak incurved. In the interior a strong septum extends from the beak about one-third the distance to the front of the shell. In nearly all specimens this septum terminates abruptly. In a few individuals, 
however, it is continued forward a short distance beyond its normal terminus as a pair of rather faintly developed, divergent, $Y$-shaped arms. Most of the specimens from Mendota, Va., show molds of the extremely slender tube, which originates on the inner surface of the shell, midway between the beak and the cardinal angle just inside the inner margin of the area, and crosses diagonally the marginal portion of the valve with a slight curve. It terminates at the side of the beak in a minute point, which apparently does not reach the outer surface of the shell.

Dorsal valve moderately and regularly concave. Outer surface marked by a minute tripartate median process just inside the hinge line. This comprises two short divergent lobes and a third median lobe stronger than the lateral one, having a length of about onethird millimeter. The interior of this valve is characterized by two slender, sharp median ridges. These diverge slightly as they extend forward from the base of the cardinal process and terminate about two-thirds the distance from the hinge line to the front. A narrow, elongate muscular scar occupies the posterior half of the space between these ridges. Outside this pair of median ridges is a second pair of poorly defined and very divergent ridges which appear to mark the outer limits of muscular areas.

The peculiar short, tripartite process on the exterior of the dorsal valve of this shell was correctly figured by Hall and Clarke ${ }^{1}$ in their work on the Brachiopoda, but in the latest figures ${ }^{2}$ of this shell a specimen which is evidently a mold of the exterior of a dorsal valve has been figured by Clarke as an interior.

Distribution.-One of the most widely distributed species in the fauna; collected at Schuylkill Haven, New Bloomfield, and Blair County, Pa.; Tonoloway, Md.; Berkeley Springs and Rees Tannery, W. Va.; Bells Valley, Clifton Forge, and Mendota, Va.

Genus PHOLIDOSTROPHIA Hall and Clarke.

Pholidostrophia pennsyluanica $n$. $\mathrm{sp.}$

Plate V, figures 1, 2.

Shell small, concavo-convex or plano-convex. Ventral valve depressed convex, greatest width at hinge line and salient cardinal angles. Surface without radiating striæ but with some indications of lamellose lines of growth. The impression of a single dorsal valve supposed to belong to this species is slightly concave and shows a very short, slender septum extending 1 millimeter from the hinge line. The collection contains six or seven specimens. An average

1 Natural history of New York, Paleontology, vol. 8, pt. 1, pl. 20, fig. 16, 1892.

2 Mem. New York State Mus. No. 9, 1908, pl. 41, fig. 16. 
specimen has a width of 8 millimeters at the hinge line and a length of 6 millimeters.

This shell resembles both $P$. iowensis (Hall) and Stropheodonta hunti Clarke in its smooth exterior. It is smaller than either of these, however, and does not possess the crescent-shaped ridges which characterize the dorsal valve of $P$. iowensis. The absence of these may leave some doubt as to the propriety of referring this shell to Photidostrophia, but the smooth surface and the general features of the shell strongly indicate its relationship to this group of the Stropheodontas.

Distribution.-Blair County, Pa.; Cumberland, Md.; Ridgeville and Berkeley Springs, W. Va.

\section{Genus LEPTOSTROPHIA Hall and Clarke.}

\section{Leptostrophia perplana (Conrad).}

Plate II, figures 12, 13; Plate III, figure 1.

1842. Strophomena perplana. Conrad, Jour. Acad. Nat. Sci. Philadelphia, vol. 8, 1842 , p. 257, pl. 14, fig. 11.

Characteristic examples of this species showing the finely striated, slightly concavo-convex shells have been found at two localities. Two of these are here figured.

Distribution.-Schuylkill Haven and Bloomfield, Pa.

\section{Genus STROPHEODONTA Hall.}

Stropheodonta patersoni Hall.

Plate III, figures 5,6 .

1857. Strophomena (Strophodonta) patersoni. Hall, Tenth Rept. New York State Cab. Nat. Hist., 1857, p. 114, figs. 1-5.

The two specimens referred to this species represent ventral valves semielliptical in outline. The hinge line is marked by very fine and shallow denticulations. The surface has about 20 strong, elevated, and widely separated strix, most of which originate at or near the beak. Eight to ten very fine strix occupy the interspaces between the stronger striæ. These interspaces are also interrupted by nodelike elevations, which appear to represent more or less regular concentric wrinkles which do not cross the stronger striæ.

Distribution.-Mendota, Va. 
Stropheodonta inequistriata Conrad.

Plate III, figures 2-4.

1842. Strophomena inæquistriata. Conrad, Jour. Acad. Nat. Sci. Philadelphia, vol. 8, 1842, p. 254, pl. 14, fig. 2.

The specimens representing this species are all ventral valves showing only external features. The surface is characterized by about 20 strong, sharp, radiating striæ, nearly half of which originate at the beak and the remainder by interstitial addition in the posterior half of the valve. Eight to ten very fine, radiating striæ occupy the space between each pair of stronger striæ at the front of the shell, and half this number in the posterior third of the shell. Extremely fine, concentric striæ cross them. Very fine denticulations border the inner margin of the hinge area.

Distribution.-New Bloomfield, Pa., and Little Moccasin Gap, Va.

\section{Genus SCHUCHERTELLA Girty.}

\section{SCHUChERTELLA PANDORA (Billings).}

Plate III, figures 7, 8.

1860. Streptorhynchus pandora. Billings, Canadian Jour., vol. 5, 1860, p. 226, figs. $12,13$.

Shell symmetrical subplano-convex, the dorsal valve being moderately convex, the ventral nearly flat or depressed convex. Width about one-fourth greater than length. Surface covered by very sharp, elevated striæ which increase almost entirely by interstitial addition and are crossed by fine, closely placed, crenulating striæ. Ventral valve with a moderately wide area, which is vertically striated and inclined backward. Triangular delthyrium closed by a convex deltidium. Valve slightly convex in the umbonal region and flattened toward the margin. Dorsal valve with a rather narrow area; surface slightly depressed along the median line and near the cardinal angles, regularly convex elsewhere. The three nearly perfect specimens which are referred to this species measure 17, 21, and 26 millimeters in length.

Distribution.-Blair County, Pa.; Little Moccasin Gap and Mendota, Va.

Schuchertella cf. Perversa (Billings).

1857. Cf. Orthis perversa. Hall, Tenth Rept. New York State Cab. Nat. Hist., 1857, p. 137.

1860. Cf. Orthisina alternata. Hall, Thirteenth Rept. New York State Cab. Nat. Hist., 1860, p. 81, figs. 1, 2; p. 112.

The collection includes a number of Schuchertellas which differ most conspicuously from the preceding species by being much 
smaller and less symmetrical. These are referred provisionally to $S$. perversa.

Distribution.-Schuylkill Haven and Blair County, Pa.; and 3 miles east of Cumberland, Md.

Genus LEPTENA Dalman.

\section{LEPTANA RHOMBOIDALIS (Wilckens).}

1769. Conchita rhomboidalis. Wilckens, Nachricht von selten Versteinerungen, 1769, p. 77, pl. 8 , figs. 43,44 .

1841. Strophomena undulosa. Conrad, Fifth Ann. Rept. Geol. Survey New York, 1841, p. 54.

Distribution.-This well-known species appears to have very scanty distribution in this fauna. It has been found at but two localities: Schuylkill Haven and New Bloomfield, Pa.

\section{Genus STROPHALOSIA King.}

Strophalosia truncata (Hall).

Plate V, figures 5-7.

1843. Strophomena pustulosa. Hall [non Productus pustulosus Phillips], Geology New York, Survey Fourth Geol. Dist., 1843, p. 189, fig. 4.

Shell small, usually 3 to 8 millimeters in width; concavo-convex, the ventral valve very gibbous and the dorsal valve slightly concave or nearly flat. The ventral valve has a sharply truncated umbo, the truncated face being often slightly concave. Hinge line generally slightly shorter than the greatest width of the shell. Surface of valve covered by irregularly placed short ridgelike tubercles and fine concentric striæ. Slender spines, which are generally missing in the specimens, extended forward from the tubercles. The dorsal valve has the hinge line marked by four or five coarse crenulations or corrugations on each side of the beak. These are seen on both sides of the valve. Surface of valve marked by a few spine bases. Interior of valve with a very slender linear septum extending nearly to middle of valve but not reaching the hinge line.

This is a very common and widely distributed species occurring both in the soft shales and the hard limestone bands of the beds holding this fauna.

Distribution.-Schuylkill Haven, McVeytown, Perry County, and Blair County, Pa.; Cumberland, Md.; Ridgeville, W. Va.; Little Moccasin Gap and Mendota, Va. 
Genus PRODUCTELLA Hall.

Productella navicella Hail.

Plate V, figure 3.

1857. Productus navicellus. Hall, Tenth Rept. New York State Cab. Nat. Hist., 1857, p. 172.

1867. Productella navicella. Hall, Nat. Hist. New York, Paleontology, vol. 4, 1867, p. 156, pl. 23, figs. 1-3, 9-11.

This species is represented in the collection by two specimens, a fragmentary dorsal valve and a ventral valve. The latter agrees with Hall's figures and description of the species in its gibbous arcuate form, concentric striæ, and spines, but has on its anterior two-thirds costæ which are rather stronger and more regular than indicated by Hall. There are about twenty-one of these at the anterior margin of the shell.

Distribution.-Schuylkill Haven, Pa.

\section{Genus LEPT杘ISCA Beecher.}

\section{LEPTÁNISCA AUSTRALIS n. sp.}

Plate IV, figures 8-12.

Outline variable, as shown in figure; length generally less than width; hinge line somewhat shorter than greatest width of shell. Shell concavo-convex. Ventral valve moderately convex. Surface marked by fine radiating striæ, which are clearly defined only in the anterior part of the shell, and which are crossed by very fine concentric striæ and stronger lines of growth. The muscular pit of the ventral valve is bordered laterally by the dental lamellæ which curve toward each other slightly near the anterior margin of the pit. These lamellæ, as they extend into the shell and away from the surface of the valve, are inclined laterally or away from each other. A short, low median septum extends across the muscular pit from the posterior nearly or quite to the anterior margin of the pit. Molds of the interior of the ventral valve indicate a strongly postulose surface, increasing regularly in coarseness from the margin of the shell to the margin of the muscular impression. The collection contains a single, somewhat imperfect, mold of the interior of a dorsal valve believed to belong to this species. The distinctly bipartite character of the posterior portion of the cardinal process is shown and, somewhat indistinctly, the quadripartite appearance of the anterior portion of the process is seen. A low thick median ridge is present in the anterior part of the mold.

The species of this genus from America ${ }^{1}$ previously described are all Helderberg shells. In surface characters they are quite unlike the

1 I am informed by Prof. Charles Schuchert (letter of Mar. 14, 1912) that Leptænisca is represented in the Silurian of Gotland by Strophomena rugata Lindström. He says further, "In this connection we should not forget that Davidsonia bouchardiana is undoubtedly closely related to Leptænisca and this specics may have come directly out of $L$. rugata (Lindström). All these forms appear to be related to Leptæna rhomboidalis." 
present species. Two of them appear from the figures to be nonstriated species, but the third, L. concava, has radiating striæ of unequal strength, each fifth or sixth being stronger than the intermediate ones. In this species the striæ are all of about equal strength.

Distribution.-This species occurs in a soft black clay shale about 30 feet above the Oriskany sandstone, $1 \frac{3}{4}$ miles south of Berkeley Springs, W. Va., and in a drab shale about same distance above the Oriskany at New Bloomfield, Pa.

Genus DALMANELIA Hall and Clarke.

Dalmanella lenticularis (Vanuxem).

Plate V, figures 12-16.

1842. Orthis lenticularis. Vanuxem [non Wahlenberg], Geology of New York, Survey Third Geol. Dist., 1842, p. 139, fig. 4.

Shell suborbicular, subplano-convex. Cardinal angles obtuse or rounded. Greatest width about one-fourth greater than length of hinge line. Ventral valve with a subcarinate gently rounded median elevation from which the shell slopes regularly to each side. A welldeveloped muscular impression bordered laterally by strong hinge teeth characterizes the interior. The dorsal valve is depressed convex, with a shallow but distinct mesial depression extending the length of the shell. A strongly marked muscular scar extends to the middle of the valve. A broad, low, and in some specimens indistinct median ridge divides it longitudinally. Posteriorly it terminates in a bifurcated cardinal process.

The entire surface is covered by coarse bifurcating striæ, somewhat irregular in size, grouped in fascicles of four or five. These are crossed by fine concentric striæ. The specimens are somewhat smaller than those figured by Hall.

Distribution.-Abundant throughout most of the region. Has been collected at New Bloomfield and McVeytown, Pa.; Berkeley Springs and Ridgeville, W. Va.; Tonoloway, Md.; and Clifton Forge, Va.

\section{Genus RHIPIDOMELLA Oehlert.}

Rhipidomella vanuxemi (Hall).

Plate V, figures 17-19.

1857. Orthis vanuxemi. Hall, Tenth Rept. New York State Cab. Nat. Hist., 1857, p. 135 , figs. $1-7$.

The specimens referred to this species are a little smaller than the average size of $R$. vanuxemi as seen in the Hamilton. Few of those observed exceed a length of 14 and a width of 16 millimeters, these being the dimensions of one of the larger specimens. In other fea- 
turés than size they correspond closely to the ordinary type of this shell.

Distribution.-McVeytown and New Bloomfield, Pa.: Tonoloway, Md.; and Ridgeville, W. Va.

\section{Genus LEIORHYNCHUS Hall.}

LEIORHYNCHUS cf. LIMITARE.

1842. Cf. Orthis limitaris. Vanuxem, Geology of New York, Survey Third Geol. Dist., 1842, p. 146, fig. 3.

A form closely resembling the characteristic Marcellus species $L$. limitare occurs in one of the Virginia faunules on James River. It has not been observed elsewhere below the Marcellus fauna.

Distribution.-Bells Valley, Va.

Genus ATRYPA Dalman.

Atrypa Reticularis (Linn.).

Plate V, figures 24,25 .

1767. Anomia reticularis. Linné, Systema Naturæ, ed. 12, vol. 1, 1767, p. 1132.

1867. Atrypa reticularis. Hall, Nat. Hist. New York, Paleontology, vol. 4, 1867, p. 316, pl. 52, figs. 1-3, 7-12; pl. 53, figs. 3-19; pl. 53A, figs. 22, 23.

This species is not as generally distributed as some others but is rather frequently found in the impure limestone bands. When present it is apt to occur in abundance.

It shows a stage of development of the specific characters similar to that generally seen in the Onondaga fauna. Figures 11 to 13 of Hall's illustrations of the species very well represent the average of the type seen in this fauna both as to size and general proportions. The shell is generally moderately gibbous with a sinus which varies from well developed to a slightly sinuous line at the front. The breadth generally slightly exceeds the length, but the reverse is sometimes seen, as in the specimen figured. The maximum width observed is 27 millimeters.

None of the large highly ventricose or lamellose forms frequently seen in the Devonian of the Central States have been observed in this fauna.

Distribution.-Schuylkill Haven, New Bloomfield, Blair County, Pa.; Little Moccasin Gap, Bells Valley, Va.; Berkeley Springs and Ridgeville, W. Va. 


\title{
Genus CYRTINA Davidson.
}

\section{Cyrtina hamiltonensis Hall.}

\author{
Plate V, figure 4.
}

1857. Cyrtia hamiltonensis. Hall, Tenth Ann. Rept. New York State Cab. Nat. Hist., 1857, p. 166.

1867. Cyrtina hamiltonensis. Hall, Nat. Hist. New York, Paleontology, vol. 4, 1867, p. 268, pl. 27 , figs. $1-4$.

This species is represented in the collection by a ventral and dorsal valve. These exhibit most of the characteristic features of the species-high area and slightly twisted beak in ventral valve, entire surface finely punctate with three or four rounded plications on each side of the fold and sinus. In the extreme weakness and indistinctness of the outer-plications, however, these specimens differ somewhat from the forms of $C$. hamiltonensis seen in the Hamilton.

Distribution.-New Bloomfield, Pa.

\section{Genus SPIRIFER Sowerby.}

\section{Spirifer aCuminatus (Conrad).}

Plate VI, figures $17,18$.

1839. Delthyris acuminata. Conrad, Third Ann. Rept. New York Geol. Survey, 1839 , p. 65.

1842. Delthyris prora. Conrad, Jour. Acad. Nat. Sci. Philadelphia, vol. 8, 1842, p. 263.

1843. Terebratula acuminatissima. Castelnau, Essai Syst. Silurien de l'Amérique Septentrionale, 1843, p. 40, pl. 14, fig. 16.

Shell large and ventricose with valves forming a prominent $V$-shaped elevation at the front. Ventral valve is impressed by a broad deep angular sinus which is greatly extended upward at the front. Transverse striæ mark the concave surface of the ventral valve.

Dorsal valve with sharp angular fold extending from the beak to the front. From the sides of this fold the surface of the valve slopes abruptly to the lateral and anterior margins.

Entire surface of shell covered by strong radiating plications; the intermediate ones bifurcate near the middle of the valve, giving dichotomous plications over the anterior median portion of the shell. These plications are crossed by fine concentric striæ which become somewhat lamellose near the front. Traces of the fimbriate character of these can be seen on a portion of the shell.

Distribution.-Schuylkill Haven, Pa.

$20495^{\circ}-$ Bull. 508-12—6 


\section{SPIRIFER VARICOSUS Hall.}

Plate VI, figure 16.

1857. Spirifer varicosa. Hall, Tenth Rept. New York State Cab. Nat. Hist., 1857, p. 130.

1861. Spirifer varicosa. Billings, Canadian Jour., vol. 6, 1861, p. 255. figs. 63, 64.

This shell is represented by a single well-preserved dorsal valve from Virginia and several fragmentary specimens from Pennsylvania. The hinge line is rather long, terminating in salient angles. On the Virginia specimen there are 10 plications on each side of the fold, all strong and elevated except near the cardinal angles, where one or two are short and indistinct. The median fold is duplicate, a depressed line running down the middle. Strong lamellose striæ cross the plications and fold. Very fine radiating striæ are visible over the best-preserved portions of the shell.

Distribution.-Mendota, Va.; Schuylkill Haven, Pa.

\section{Genus RETICULARIA McCoy.}

Reticularia cf. fimbriata (Conrad).

1842. Cf. Delthyris fimbriatus. Conrad, Jour. Acad. Nat. Sci. Philadelphia, vol. 8, 1842, p. 263.

1858. Cf. Spirifer fimbriatus. Hall, Geol. Survey Iowa, vol. 1, pt. 2, 1858, p. 505, pl. 4, fig. 5 .

The collection contains three small specimens of a Reticularia having a breadth along the hinge line of about 5 millimeters and having three to four plications on each side the fold and sinus. These probably represent either immature individuals or a dwarfed form of $R$. fimbriata.

A fourth specimen in the collection is a fragmentary ventral valve comparable and possibly identical with this species. The broad rounded sinus and the four or five rounded plications on each side of it are covered by very fine radiating striæ. These are crossed by concentric striæ which give a slightly fimbriate appearance to the surface of the shell, which, however, is much less pronounced than in ordinary examples of $R$. fimbriata.

Distribution.--Selinsgrove Junction, Pa., and Cumberland, Md.

Reticularia cf. modesta (Hall).

Plate VII, figure 6.

1859. Cf. Spirifer modestus. Hall, Nat. Hist. New York, Paleontology, vol. 3, 1859, p. 203, pl. 28, fig. 1 .

The southwestern Virginia collection includes a single brachial valve of uncertain specific identity which is comparable with $R$. modesta.

Distribution.-Mendota, Va. 


\section{Genus AMBOCGLIA Hall.}

\section{Ambocolia umbonata (Conrad).}

1842. Orthis umbonata. Conrad, Jour. Acad. Nat. Sci. Philadelphia, vol. 8, 1842, p. 264 , pl. 14, fig. 4.

1860. Ambocolia umbonata. Hall, Thirteenth Rept. New York State Cab. Nat. Hist., 1860, p. 71.

The specimens referred to this species show considerable variation and may possibly include an undescribed species. Although one of the most abundant and widely distributed species in the fauna, it generally occurs in soft shales, which furnish rather poorly preserved and often flattened material, whose character scarcely justifies detailed consideration of the variations. Hall ${ }^{1}$ states that the surface of this species is marked by "very fine radiating and concentric striæ." In most of the specimens, both in my collection and in other collections bearing the name $A$. umbonata, the surface is smooth. Some specimens, however, show well developed concentric striæ, but none have been observed showing radiating striæ. Shells with a strongly lamellose dorsal valve are not uncommon. These as well as smooth shells frequently show a distinct fold near the front of the dorsal valve.

Distribution.-Schuylkill Haven, New Bloomfield, Blair County, Pa.; Hancock and Cumberland, Md.

Amboccelia umbonata var. cf. Nana Grabau.

Plate V, figures 20-23.

1900. Amboccelia umbonata var. nana n. var. Grabau, Sixteenth Rept. State Geologist New York, for 1896, 1900, pp. 276-278, text figs. 3-7.

An Amboccelia with a rough surface marked with numerous minute tubercle-like elevations, apparently spine bases, is represented by a few individuals at two localities. The ventral valve shows a distinct sinus and lamellose surface. The dorsal valve has not been observed. This little shell resembles A. nana and is probably identical with it.

Distribution.-McVeytown, Pa., and Rees Tannery, Mineral County, W. Va. 
Genus ANOPLOTHECA Sandberger.

\section{Anoplotheca acutiplicata (Conrad).}

Plate VI, figures 1-15.

1841. Atrypa acutiplicata. Conrad, Fifth Ann. Rept. New York Geol. Survey, 1841, p. 54.

1862. Atrypa acutiplicata. Hall, Fifteenth Rept. New York State Cab. Nat. Hist., 1862, pl. 11, fig. 17.

The shell is planoconvex in form, orbicular to ovate acute in outline. Shell with six to eight and rarely nine strong angular plications on each valve. On the ventral valve one of these occupies the sinus. while two are elevated into a fold on the anterior half of the opposite valve. Posteriorly they are depressed slightly below the adjacent plications. In some gerontic shells the lateral plications show a tendency to become obsolete toward the anterior margin of the shell. Strong lamellose lines of growth cross the plications. This shell as a rule is much depressed in form but occasionally a markedly gibbous form is seen. In one of these the depth of the shell equals more than half its length. There is a considerable variation in the amount of elevation of the folds at the front in shells from the same locality and zone, as will be seen in the figures. Average-sized specimens have a breadth of 12 to 15 millimeters, but a few individuals show a width of 20 millimeters. The breadth usually slightly exceeds the length.

A strong median ridge and dental sockets characterize the interior of the dorsal valve. Corresponding to the latter in the ventral valve are prominent articulating teeth. Slightly anterior to these in the median line is a small well-marked anterior adductor muscular impression. The borders of the posterior impression may or may not be well marked. In many specimens a delicate linear ridge 3 or 4 millimeters in length passes longitudinally through the muscular impression. In some specimens this ridge is very short and is confined to the anterior part of the impression. It may be crossed by a shorter transverse ridge limiting the anterior margin of the ridge and giving it a barblike effect.

Comparison of the types of this species with the specimens from Pennsylvania and from localities farther south shows that the latter undoubtedly belong to this species. For convenience of comparison of the figures one of the types is here refigured in connection with my specimens.

Distribution.-Probably the most abundant and widely distributed species in the fauna. Occurs in most of the collections obtained from New York to southwestern Virginia. 
Anoplotheca camilla (Hall).

1867. Calospira concava. Hall [non Hall, 1863], Nat. Hist. New York, Paleontology, vol. 4, 1867, p. 329.

1867. Colospira camilla. Hall, idem, pl. 52, figs. 13-19.

This rather diminutive brachiopod is represented by only a few positively determined specimens in the collections. Although comparatively rare, it has been found in both the noncalcareous shale and the limestone in three States, and is probably coextensive with the fauna in its distribution.

Distribution.-Blair County, Pa.; Cumberland, Md.; and Bells Valley, Va.

\section{Genus PENTAgONIA Cozzens.}

Pentagonia unisulcata (Conrad).

1841. Atrypa unisulcata. Conrad, Fifth Ann. Rept. Geol. Survey, New York, 1.841, p. 56.

1862. Atrypa unisulcata. Hall, Fifteenth Rept. New York State Cab. Nat. Hist., 1862, pl. 11, fig. 10.

This well-known brachiopod is represented in the collections by fragmentary material unsuitable either for figuring or for detailed description.

Distribution.-Schuylkill Haven, Pa.; Little Moccasin Gap, Va. (?).

Genus MERISTELLA Hall.

Meristella nasuta (Conrad).

Plate VII, figure 7.

1842. Atrypa nasuta. Conrad, Jour. Acad. Nat. Sci. Philadelphia, vol. 8, 1842, p. 265. 1860. Meristella nasuta. Hall, Thirteenth Rept. New York State' Cab. Nat. Hist., 1860, p. 93, figs. 8-9.

This shell is represented by the ventral valves of two mature individuals from southwestern Virginia. The ventral valve is very gibbous, the profile seen from the side forming nearly a half circle. Regularly convex in the median line without trace of sinus. A prominent linguiform extension characterizes the middle of the anterior margin. Surface marked by a few lamellose lines of growth on the anterior half of the shell. Other features not preserved. A deep subquadrate muscular scar marks the interior of the valve.

Distribution.-Mendota and Little Moccasin Gap, Va. 
Genus NUCLEOSPIRA Hall.

- Nucleospira concinNa (Hall).

Plate VII, figures 3-5.

1843. Atrypa concinna. Hall, Geology of New York, Survey Fourth Geol. Dist., 1843, p. 200 , fig. 3 .

1867. Nucleospira concinna. Hall, Nat. Hist. New York, Paleontology, vol. 4, 1867, p. 279 , pl. 45 , figs. $33-57$.

This species is represented by numerous ventral valves, but the dorsal valve has not been observed. Nearly all of the specimens represent casts of the interior, but one silicified specimen shows the bases of the fine setæ over the anterior third of the shell and a highly papillose surface over the remainder. Another of the external characters exhibited in these specimens is a narrow impressed line extending from the beak to the front, varying in intensity in different individuals. The molds of the ventral valve show a narrow, low septum extending from the beak about one-third the distance to the front. The outline of the muscular scars is not very clearly shown in the specimens. Two narrow ridges on either side the septum appear to limit them in the casts.

Distribution.-New Bloomfield and Blair County, Pa.; Berkeley Springs and Rees Tannery, Mineral County, W. Va.; Cumberland and Tonoloway, Md.; Bells Valley and Mendota, Va.

\section{Genus MARTINIA McCoy.}

\section{Martinia? sp.}

A single dorsal valve of undetermined species is doubtfully referred to this genus. It is slightly convex and characterized by a broad, low fold rising scarcely above the rest of the valve.

\section{Genus CRAN ExNA Hall and Clarke.}

Cranena ef. romingeri (Hall).

Plate VII, figures 1, 2.

1863. Cf. Terebratula romingeri. Hall, Sixteenth Rept. New York State Cab. Nat. Hist., 1863, p. 48, figs. 22, 23.

Shell small, subcircular or elliptical, the front often truncate. Surface covered with fine concentric striæ, often with strong lamellose lines toward the front. Shell structure punctate. This shell, which may provisionally be referred to $C$. romingeri, occurs in great numbers as flattened shells in the shale at two localities. It is much smaller than the representatives of the species figured by Hall, rang.ing from $2 \frac{1}{2}$ to 8 millimeters in length.

Distribution:-Bells Valley, Va., and Ridgeville, W. Va. 


\section{PELECYPODA.}

\section{Genus GRAMMMYSIA De Verneuil.}

\section{Grammysia sp.}

This genus is represented by a single specimen showing only the anterior portion of a right valve. It represents a species of the same general type as $G$. subarcuata.

Distribution.-Cumberland, Md.

\section{Genus PALEONEILO Hall.}

\section{Palajoneilo cf. constricta (Conrad).}

Plate VII, figure 10.

1842. Cf. Nuculites constricta. Conrad, Jour. Acad. Nat. Sci. Philadelphia, vol. 8, 1842 , p. 249 , pl. 15, fig. 8 .

1843. Nucula bellatula. Hall, Nat. Hist. New York, Geology, vol. 4, 1843, p. 196, text fig. 7, p. 197, table illust. 40, fig. 7 .

1847. Nucula bellatula. Owen (Hall), Am. Jour. Sci., 2d ser., vol. 3, 1847, p. 62, fig. 7 , in text.

1857. Nucula bellatula. Billings, Canadian Nat. Geology, vol. 1, 1857, p. 473, pl. opp. p. 400 , fig. 6.

1861. Nucula bellatula. Lincklaen, Fourteenth Rept. New York State Cab. Nat. Hist. (August), 1861, pl. 14, fig. 7.

1869. Cf. Palxoneilo constricta. Hall, Prelim. Notice Lamellibr., pt. 2, December, 1869, p. 7.

1882. Cf. Palæoneilo constricta. Whitfield, Geology of Wisconsin, vol. 4, 1882, p. 335, pl. 26, figs. 13, 14.

1883. Cf. Palæoneilo constricta. Hall, Nat. Hist. New York, Paleontology, vol. 5, pt. 1, Lamellibr. (adv. copy), 1883, pl. 48, figs. 1-15; pl. 51, fig. 17.

1884. Cf. Palæoneilo constricta. Hall, [First] Rept. State Geologist New York, 1884, pl. 7, fig. 16.

1885. Cf. Palæoneilo constricta. Hall, Nat. Hist. New York, Paleontology, vol. 5, pt. 1, Lamellibr., pt. 2, 1885, p. 333, pl. 48, figs. 1-16; pl. 51, fig. 17.

1889. Cf. Palæoneilo constricta. Miller, North Am. Geol. and Pal., 1889, p. 499, text fig. 881.

1896. Cf. Palæoneilo constricta. Kindle, Bull. Am. Paleontology, vol. 2, 1896, p. 42. 1899. Cf. Palæoneilo constricta. Grabau, Bull. Buffalo Soc. Nat. Sci., vol. 6, 1899, p. 256, text fig. 173.

1900. Cf. Palæoneilo constricta. Grabau, Sixteenth Rept. State Geologist New York, for 1896, 1900, p. 257.

1903. Cf. Palæoneilo constricta. Cleland, Bull. U. S. Geol. Survey No. 206, 1903, p. 64 .

1904. Cf. Palæoneilo constricta. Clarke, Mem. New. York State Mus. No. 6, 1904, pp. 311, 356, 357, pl. 15, figs. 9-13.

1904. Cf. Palroneilo constricta. Raymond, Annals Carnegie Mus., vol. 3, 1904, p. 169.

1906. Cf. Palæoneilo constricta. Grabau, Bull. New York State Mus. No. 92 (Fiftyeighth Ann. Rept., vol. 3, for 1904), 1906, p. 330.

1906. Palæoneilo constricta. Slocom, Field Columbian Mus., geol. ser., vol. 2, No. 8, 1906, p. 265. 
1908. Palæoneilo cf. constricta. Clarke, Mem. New York State Mus. No. 9, 1908, p. 233 , pl. 24 , fig. 6 .

1911. Palæoneilo constricta. Cleland, Bull. Wisconsin Geol. and Nat. Hist. Survey No. 21, 1911, p. 102, pl. 20, figs. 9, 19, 20, 21, 22.

A Palæoneilo having apparently most of the essential characters of $P$. constricta occurs in the same bed with numerous specimens of Chonetes mucronatus. It has the constricted postero-basal margin and fine concentric striæ of that species, but is rather more gibbous in the umbonal region than ordinary examples of $P$. constricta.

Distribution.-Blair County, Pa., and Cumberland, Md.

\section{Genus BUCHIOLA Barrande.}

Buchiola halli Clarke.

1885. Glyptocardia speciosa (pars). Hall, Nat. Hist. New York, Paleontology, vol. 5, pt. 1, Lamellibr., pt. 2, 1885, p. 426, pl. 70, fig. 9 [not figs. 2-8 nor pl. 80, fig. 10].

1904. Buchiola halli. Clarke, Mem. New York State Mus. No. 6, 1904, pp. 301-302, pl, 10, figs. 15, 16.

Clarke has separated under the name Buchiola halli a Marcellus species which Hall originally included under the same name with the Portage species Glyptocardia speciosa. ${ }^{1}$ The two forms are quite distinct and with the larger Marcellus species I have identified several speci-. mens showing the strong nodose ribs and large size characterizing $B$. halli. The smaller species (Buchiola speciosa) occurs at the Portage horizon in most of the sections but has not been observed in the Onondaga.

Distribution.-Sassin, Va.

Genus NUCULA Lamarck.

\section{Nucula ef. CORBULIFormis Hall.}

Plate VII, figure 15.

1869. Cf. Nucula corbuliformis. Hall, Prelim. Notice Lamellibr., pt. 2, December, 1869 , p. 2.

1883. Cf. Nucula corbuliformis. Hall, Nat. Hist. New York, Paleontology, vol. 5, pt. 1, Lamellibr. (adv. copy), 1883, pl. 46, figs. 24-37.

1885. Cf. Nucula corbuliformis. Hall, Nat. Hist. New York, Paleontology, vol. 5, pt. 1, Lamellibr., pt. 2, 1885, p. 319, pl. 46, figs. [10, 11]? 24-34 [35-37]?.

1889. Cf. Nucula corbuliformis. I.esley, Geol. Survey Pennsylvania, Rept. P4, 1889, p. 469, 3 text figs.

1896. Cf. Nucula corbuliformis. Kindle, Bull. Am. Paleontology, vol. 2, 1896, p. 42.

1899. Cf. Nucula corbuliformis. Grabau, Bull. Buffalo Soc. Nat. Sci., 1899, p. 253, text fig. 169A.

1901. Cf. Nucula corbuliformis?. Kindle, Twenty-fifth Ann. Rept. Indiana Dept. Geol. Nat. Res., 1901, p. 677, pl. 14, fig. 5. 
1903. Cf. Nucula corbuliformis. Cleland, Bull. U. S. Geol. Survey No. 206, 1903, p. 63.

1904. Cf. Nucula corbuliformis. Raymond, Annals Carnegie Mus., vol. 3, 1904, p. 169.

Three or four small Nuculas found in the collection are closely allied to, if not identical with, $N$. corbuliformis. The figured specimen is somewhat flattened by pressure. In general outline and in the fine close concentric striæ it does not appear to differ materially from the New York examples of $N$. corbuliformis.

Distribution.-McVeytown, Pa.; Berkeley Springs, - $\dot{\mathrm{W}}$. Va.; and Bells Valley, Va.

\section{Genus NUCULITES Conrad.}

Nuculites modulatus n. sp.

Plate VII, figures 13, 14.

Shell elongate ovate, length usually about two-thirds the width. Cardinal line nearly straight or slightly arcuate. Basal margin regularly arcuate, anterior and posterior margins broadly rounded. A nearly vertical clavicle extends from the hinge line just anterior to the beaks two-thirds the distance to the basal margin.

Valves moderately convex in the umbonal region, less convex in the lower and posterior portions. Beaks anteriorly placed, appressed and not rising above the hinge line. Umbonal slepe undefined and broadly rounded, blending with the depressed posterior border. Transverse teeth slightly arched, with the crest toward the beaks. Surface marked by fine concentric striæ. Three specimens measure 7,8 , and 8 millimeters in height and 11,14 , and 13 millimeters in length. This species is rather closely allied to Nuculites oblongus from the Hamilton. It is distinguished from this shell, however, by the greater proportional width, the broader, more regularly rounded, posterior margin, and the less pronounced umbonal slope.

Distribution.-McVeytown, Pa.; Cumberland, Md.; Ridgeville, W. Va.; Bells Valley, Va.

\section{Genus LUNULICARDIUM Munster.}

\section{LunULICARDIUM CURTUM Hall.}

Plate VII, figure 16.

1870. Lunulicardium curtum. Hall, Prelim. Notice Lamellibr., pt. 2, 1870, p. 97.

1883. Lunulicardium curtum. Hall, Nat. Hist. New York, Paleontology, vol. 5, pt. 1, Lamellibr. (adv. copy), 1883, pl. 71, figs. 12-23.

1884. Lunulicardium curtum. Hall, [First] Rept. State Geologîst New York, 1884, pl. 10, fig. 1.

1885. Lunulicardium curtum. Hall, Nat. Hist. New York, Paleontology, vol. 5, pt. 1, Lamellibr., pt. 2, 1885, p. 437, pl. 71, figs. 18-23.

1889. Lunulicardium curtum. Miller, North Am. Geol. and Pal., 1889, p. 486, text fig. 841 . 
1899. Lunulicardium curtum. Grabau, Bull. Buffalo Soc. Nat. Sci., vol. 6, 1899, p. 264, text fig. 185.

1903. Lunulicardium curtum Cleland, Bull. U. S. Geol. Survey No. 206, 1903, p. 66. 1903. Lunulicardium curtum. Wilson, Proc. Onondaga Acad. Sci., Syracuse, vol. 1, 1903, p. 85.

The single specimen referred to this species is a mold which shows the plications and surface striæ imperfectly. The features that are clearly shown are an ovate-subtrigonal outline with anterior and basal margins regularly curving. Entire posterior side truncate with narrow alate margin. Valves moderately convex. Beaks prominent, incurved, and directed forward. Surface marked by about 25 plications.

Distribution.-Occurs in dark shale associated with Anoplotheca acutiplicata at Ridgeville, W. Va.

\title{
Genus PTEROCHEnIA Clarke.
}

\section{Pterochania fragilis (Hall.)}

\author{
Plate VII, figures $8,9$.
}

1843. Avicula fragilis. Hall, Nat. Hist. New York, Geology, vol. 4, 1843, p. 222, text figs. 1, 2; table illus. 51, figs. 1, 2.

1847. Avicula fragilis. Owen (Vanuxem), Am. Jour. Sci., 2d ser., vol. 3, 1847, p. 165, figs. 1, 2, in text.

1860. Avicula fragilis. Emmons, Man. Geology, 1860, p. 148, text fig. 2 .

1861. Avicula fragilis. Lincklæn, Fourteenth Rept. New York State Cab. Nat. Hist. (August), 1861, pl. 16, figs. 16, 18.

1877. Aviculopecten fragilis. S. A. Miller, Cat. North Am. Pal. Fos., 1877, p. 184.

1883. Lunulicardium fragile. Häll, Nat. Hist. New York, Paleontology, vol. 5, pt. 1, Lamellibr. (adv. copy), 1883, pl. 71, figs. 1-14.

1884. Lunulicardium fragile. Hall, [First] Rept. State Geologist New York, 1884, pl. 10, fig. 3.

1885. Lunulicardium fragile. Clarke, Bull. U. S. Geol. Survey No. 16, 1885, p. 23.

1885. Lunulicardium fragile. Hall, Nat. Hist. New York, Paleontology, vol. 5, pt. 1, Lamellibr., pt. 2, 1885, p. 434, pl. 71, figs. 1-14.

1885. Lunulicardium fragile. Clarke, Bull. U. S. Geol. Survey No. 16, 1885, p. 62.

1887. Lunulicardium fragile. Williams, Bull. U. S. Geol. Survey No. 41, 1887, p. 38, pl. 3, fig. 7 .

1889. Cf. Lunulicardium fragile. Lesley, Geol. Survey Pennsylvania, Rept. P4, 1889, p. 363. (Left-hand text figure only.) Also vol. 2, p. I.

1899. Lunulicardium fragile. Grabau, Bull. Buffalo Soc. Nat. Sci., vol. 6, 1899, p. 263, text fig. 183.

1900. Lunulicardium fragile. Grabau, Sixteenth Rept. State Geologist New York, for 1896,1900 , p. 259.

1901. Lunulicardium fragile. Kindle, Twenty-fifth Ann. Rept. Indiana Dept. Geol. Nat. Res., 1901, p. 575.

1902. Lunulicardium fragile. Wood, Bull. New York State Mus. No. 49, 1901, p. 168, pl. 9, figs. 18, 19.

1903. Lunulicardium fragile. Cleland, Bull. U. S. Geol. Survey No. 206, 1903, p. 66.

1904. Pterochænia fragilis. Clarke, Mem. New York State Mus. No. 6, 1904, p. 249, pl. 5, figs. 1-10.

1906. Pterochænia fragilis. Kindle, Jour. Geology, vol. 14, No. 7, 1906, p. 633. 
This species has been observed at but one locality, where it occurs abundantly. The specimens all appear to belong to the "broadly spatulate or elongate form" ${ }^{1}$ which Clarke considers the normal and usual expression of the species. The shells show some variability in the surface markings. The lines of growth give a distinctly lamellose appearance to the surface of some specimens which is not seen in others. Fine radiating striæ have been observed on the surface of but one specimen. An average specimen has a length and height of 5 millimeters. A larger fragmentary specimen shows a height of 15 millimeters.

Distribution.-Occurs in dark shale at Sassin, Va.

Genus PTERINEA Goldfuss.

1

Pterinea sp. undet.

Plate VIII, figure 4.

The collection from southwestern Virginia includes two left valves of an undetermined Pterinea. The best-preserved specimen, which is figured, though nearly flat, snows evidence of having been moderately convex in the crumpled fracture line resulting from pressure. The shell is large and erect; height and length nearly equal; margin regularly curved. Hinge line straight, equal to or greater than the greatest length of the shell. Beak anterior; ear small, limited by a distinct sulcus; wing broad and rather sharply delimited from the rest of shell. Surface of the valve marked by strong elevated radii which are separated by wide flat interspaces. These show a slight posterior curvature in the upper portion of their course. The ear and wing are marked by radii of much less strength than the body of the valve, but the entire surface is cancellated by concentric striæ of equal strength, which are rather widely spaced. In outline and general appearance this shell is comparable with $P$. consimilis of the Chemung. The radii of $P$. consimilis, however, are flattened and those of this species are rounded.

Distribution.-Little Moccasin Gap, Va.

\section{Genus CONOCARDIUM Bronn.}

Conocardium cf. CUNEUS var. NASUTUM.

1883. Cf. Conocardium nasutum. Hall, Nat. Hist. New York, Paleontology, vol. 5, pt. 1, Lamellibr. (adv. copy), 1883, pl. 67, figs. 12-20.

1885. Cf. Conocardium cuneus var. nasutum. Hall, Nat. Hist. New York, Paleontology, vol. 5, pt. 1, Lamellibr., pt. 2, 1885, p. 410, pl.'67, figs. 12-20.

1901. Cf. Conocardium cuneus var. nasutus. Kindle, Twenty-fifth Ann. Rept. Indiana Dept. Geol. Nat. Res., 1901, p. 688. 
The collections from Pennsylvania and Virginia contain two poorly preserved specimens of a small Conocardium. They appear, so far as can be judged from the character of the material, to represent this species.

Distribution.-New Bloomfield, Pa., and Little Moccasin Gap, Va.

\section{Genus ACTINOPTERIA Hall.}

\section{Actinopteria muricata Hall.}

Plate VIII, figure 6.

1843. Avicula muricata. Hall, Nat. Hist. New York, Geology, vol. 4, 1843, p. 180, text fig. 5 ; p. 181; table illus. 39 , fig. 5 .

1847. Avicula muricata. Owen (Hall), Am. Jour. Sci., 2d ser., vol. 3, 1847, p. 59, fig. 5 , in text.

1883. Actinopteria muricata. Hall, Nat. Hist. New York, Paleontology, vol. 5, pt. 1, Lamellibr. (adv. copy), 1883, pl. 17, figs. 1-3.

1884. Actinopteria muricata. Hall, Nat. Hist. New York, Paleontology, vol. 5, pt. 1, Lamellibr., pt. 1, 1884, p. 108, pl. 17, figs. 1-3.

1884. Actinopteria muricata. Hall, Thirty-fifth Rept. New York State Mus. Nat. Hist., 1884, p. 297.

1884. Actinopteria muricata. Hall, [First] Rept. State Geologist New York, 1884, pl. 3, fig. 14.

1884. Actinopteria muricata. Hall, Prelim. Notice Lamellibr., pt. 1, 1884, pl. 3, fig. 14. 1885. Actinopteria muricata. Hall, Nat. Hist. New York, Paleontology, vol 5, pt. 1, 1885, p. 108, pl. 17, figs. 1-3.

1902. Actinopteria muricata. Wood, Bull. New York State Mus. No. 49, 1901 (1902), p. 168.

Shell small, oblique, and strongly auriculate. Wing triangular, flat, and mucronate. It is delimited from the body of the shell by a nearly straight line extending from the beak to the posterior margin. A shallow sulcus and broad low fold extending from the beak separates the triangular ear from the rest of the shell. A specimen of average size has a height' of $6 \frac{1}{2}$ and a length of 8 millimeters. Test covered by 12 to 18 prominent elevated striæ, widely spaced. These terminate in short spines at the margin, which are seldom preserved. Very fine radiating striæ may be observed between these on wellpreserved shells. The surface is cancellated by concentric striæ, which, together with the radiating striæ, cover the wing.

Distribution.-Occurs in soft drab shales associated with one or two other aviculoid shells in Blair County, Pa.; Ridgeville, W. Va.; and Clifton Forge, Va. 


\section{Genus AVICULOPECTEN McCoy.}

\section{Aviculopecten equilatera (Hall).}

Plate VIII, figures 2,3 .

1843. Avicula equilatera. Hall, Nat. Hist. New York, Geology, vol. 4, 1843, p. 180, text fig. 7; p. 181; table illus. 39, fig. 7 .

1847. Avicula equilatera. Owen (Hall), Am. Jour. Sci., 2d ser., vol. 3, 1847, p. 59, fig. 7 , in text.

1859. Aviculopecten equilatera. Hall, Twelfth Rept. New York State Cab. Nat. Hist., 1859 , p. 89.

1861. Avicula equilatera. Lincklæn, Fourteenth Rept. New York State Cab. Nat. Hist. (August), 1861, pl. 12, fig. 7.

1889. Aviculopecten equilaterus. Lesley, Geol. Survey Pennsylvania, Rept. P4, 1889 , p. 74,1 text fig.

1891. Aviculopecten? equilatera. Whitfield, Annals New York Acad. Sci., vol. 5, 1891, p. 551, pl. 11, fig. 16.

1893. Aviculopecten? equilatera. [May $=$ A. invalidus] Whitfield, Geol. Survey Ohio, Paleontology, vol. 7, 1893, p. 445, pl. 7, fig. 16.

Shell small and slightly oblique, depressed convex. Hinge line straight, equal to greatest length of shell. Beak nearly central on hinge line. Anterior cardinal angle apparently mucronate; margin of shell below the cardinal line slightly sinuate and gently rounded to the posterior margin, which is nearly straight but is directed slightly backward in descending from the hinge line to the rounded posterior margin. Surface covered with 15 to 20 strong rounded plications, which are crossed by finer concentric undulations.

The species is represented by two left valves which appear to be identical with the Marcellus species described by Hall.

Distribution.-Ridgeville, W. Va., and Blair County, Pa.

Genus MODIOMORPHA Hall.

\section{Modiomorpha subalata (Conrad).}

Plate.VIII, figure 1.

1841. Cypricardites subalata. Conrad, Fifth Ann. Rept. New York Geol. Survey, 1841, p. 53.

1869. Modiomorpha subalata. Hall, Prelim. Notice Lamellibr., pt. 2, December, 1869, p. 77.

1883. Modiomorpha subalata. Hall, Nat. Hist. New York, Paleontology, vol. 5, pt. 1, Lamellibr. (adv. copy), 1883, pl. 39, figs. 1-16; pl. 41, figs. 5-9.

1884. Modiomorpha subalata. Hall, [First] Rept. State Geologist New York, 1884, pl. 6, fig. 10.

1885. Modiomorpha subalata. Hall. Nat. Hist, New York, Paleontology, vol. 5, pt. 1, Lamellibr. 2, 1885, p. 283, pl. 35, figs. 6, 7; pl. 39, figs. 1-14, 16.

1889. Modiomorpha subalata. Lesley, Geol. Survey Pennsylvania, Rept. P4, 1889, p. $\bullet 416,1$ text fig.

1896. Modiomorpha subalata. Kindle, Bull. Am. Paleontology, vol. 2, 1896, p. 43.

1899. Modiomorpha subalata. Grabau, Bull. Buffalo Soc. Nat. Sci., 6, 1899, p. 250, text fig. 166.

1900. Modiomorpha subalata. Grabau, Sixteenth Rept. State Geologist New York for 1896, 1900, p. 254. 
1903. Modiomorpha subalata. Cleland, Bull. U. S. Geol. Survey No. 206, 1903, p. 70. 1906. Modiomorpha subalata. Grabau, Bull. New York State Mus., No. 92 (Fiftyeighth Ann. Rept., vol. 3 for 1904), 1906, p. 330.

1909. Modiomorpha subalata. Stauffer, Bull. Ohio Geol. Survey, 4th ser., No. 10, 1909, p. 165.

The collection contains but one specimen of this species-a right valve. Its salient features are as follows: Beak anteriorly placed; basal margin nearly straight; cardinal margin sloping upward slightly from the beak. The specimen has been broken by pressure near the middle and bent downward posteriorly. Posterior margin obliquely truncate. A strong, angular, umbonal ridge extends from the beak to the posterior basal border. Surface marked by fine concentric striæ and some lamellose lines of growth.

Distribution.-In tough dark-drab shale at Cumberland, Md.

\section{Genus CYPRICARDINIA Hall.}

\section{Cypricardinia indenta (Conrad).}

Plate VII, figures 11, 12.

1842. Cypricardites indenta. Conrad, Jour. Acad. Nat. Sci. Philadelphia, vol. 8, 1842 , p. 244, pl. 12, fig. 12.

1870. Cypricardinia indenta. Hall, Prelim. Notice Lamellibr., pt. 2, January, 1870, p. 83.

1883. Cypricardinia indenta. Hall, Nat. Hist. New York, Paleontology, vol. 5, pt. 1, Lamellibr. (adv. copy), 1883, pl. 79, figs. 6-23.

1884. Cypricardinia indenta. Hall, [First] Rept. State Geologist New York, 1884, pl. 11, figs. 11, 12.

1884. Cypricardinia indenta. Walcott, Mon. U. S. Geol. Survey, vol. 8, 1884, p. 182, pl. 5, fig. 14; pl. 15, fig. 11.

1885. Cypricardinia indenta. Hall, Nat. Hist. New York, Paleontology, vol. 5, pt. 1, Lamellibr., pt. 2, 1885, p. 485, pl. 79, figs. 6-16, 23; pl. 96, fig. 2.

1889. Cypricardinia indenta. Lesley, Geol. Survey Pennsylvania, Rept. P4, 1889, p. 176, 1 text fig.

1892. Cypricardinia cf. lamellosa. Clarke, Am. Jour. Sci., 3d ser., vol. 44, 1892, p. 413. 1899. Cypricardinia indenta. Grabau, Bull. Buffalo Soc. Nat. Sci., vol. 6, 1899, p. 268, text fig. 191.

1900. Cypricardinia indenta. Grabau, Sixteenth Rept. State Geologist New York, for 1896,1900 , p. 260.

1900. Cypricardinia indenta. Clarke, Mem. New York State Mus., vol. 3, No. $3,^{\cdots}$ ), p. 36 , pl. 4 , figs. $18-20$.

1901. Cypricardinia indenta. Kindle, Twenty-fifth Ann. Rept. Indiana Dept. Geol. Nat. Res., 1901, p. 685, pl. 15, figs. 8, 8a.

1902. Cypricardinia indenta. Wood, Bull. New York State Mus. No. 49, 1901 (1902), p. 168 .

1903. Cypricardinia indenta. Cleland, Bull. U. S. Geol. Survey No. 206, 1903, p.72.

1904. Cypricardinia indenta. Raymond, Annals Carnegie Mus., vol. 3, 1904, p. 171.

1908. Cypricardinia indenta. Kindle, Bull. Geol. Soc. America, yol. 19, 1908, p. 328.

1909. Cypricardinia indenta? Stauffer, Bull. Ohio Geol. Survey, 4th ser., No. 10, 1909, p. 165.

1911. Cypricardinia cf. indenta. Cleland, Bull. Wisconsin Geol. and Nat. Hist. Survey No. 21, 1911, p. 117, pl. 26, fig. 3. 


\section{This shell is described by Hall ${ }^{1}$ as follows:}

Shell of medium sizè, subrhomboid-ovate; length more than one-third greater than the height; basal margin nearly straight, slightly sinuate anterior to the middle. Posterior extremity abruptly rounded below and obliquely truncate above. Cardinal line straight, oblique. Anterior end very short, rounded below. Right valve convex, often extremely gibbous. Left valve usually depressed convex below and posteriorly, becoming moderately gibbous in the umbonal region. Beaks nearly anterior small and appressed, rising but little above the hinge line. Cincture distinct upon the right valve, less marked upon the left valve. Umbonal slope rounded and prominent on right valve, subangular on the left valve. Surface marked by extremely fine concentric striæ, and by unequally distant but somewhat regular, lamellose, imbricating, concentric undulations; and in well-preserved specimens the entire surface is marked by fine striæ which radiate from the apex of the shell, and in some conditions of preservation the surface shows a second set of stria vertical to the direction of the lamellæ. Four specimens measure, respectively, 11, 14, 18, and 20 millimeters in length and $7,8,11$, and 11 millimeters in height.

All the shells studied by the writer display prominently the peculiar characteristic criss-cross ornamentation characterizing the strongly lamellose surface, which is mentioned by Hall as an occasional feature of this shell. The sculpturing and the fine concentric lines mentioned by Hall have both been observed on but one specimen. The transverse sculpture is the coarser of the two, and when strongly developed tends to obliterate the very fine concentric striæ. The specimens studied are much smaller than those described by Hall but show no other differences from those of the New York fauna.

Distribution.-Mendota and Little Moccasin Gap, Va.

\section{Genus LEIOPTERIA Hall.}

\section{Leiopteria Lefevis Hall.}

Plate VIII, figure 5.

1843. Avicula lævis. Hall, Geol. Survey New York, Rept. Fourth District, 1843, p. 181.

1847. Avicula lavis. Owen (Hall), Am. Jour. Sci., 2d ser., vol. 3, 1847, p. 59, text fig. 6.

1859. Pteronites? lavis. Hall, Twelfth Rept. New York State Cab. Nat. Hist., 1859, p. 89.

1861. Avicula lavis. Lincklaen, Fourteenth Rept. New York State Cab. Nat. Hist., 1861, pl. 12, fig. 6 .

1883. Leiopteria lavis. Hall, Nat. Hist. New York, Paleontology, vol. 5, pt. 1, Lamellibr. (adv. copy), 1883, pl. 17, figs. 5-11.

1884. Leiopteria lævis. Hall, Nat. Hist. New York, Paleontology, vol. 5, pt. 1, Lamellibr., pt. 1, 1884, p. 158, pl. 17, figs. 5-11; pl. 20, fig. 5.

1884. Leiopteria levis. Hall, Thirty-fifth Rept. New York State Mus. Nat. Hist., 1884, p. 334.

1889. Pteronites lavis. Lesley, Rept. P4, Geol. Survey Pennsylvania, 1889, p. 817, text figs.

1903. Leiopteria l:xvis. Cleland, Bull. U. S. Geol. Survey No. 206, 1903, p. 67. 
This species is represented in the collection by a single left valve. Hall ${ }^{1}$ described the species as follows:

Shell small, subrhomboidal; body obliquely ovate; length and height nearly equal; greatest length below the middle; margins regularly rounded, somewhat extended on the postbasal side. Left valve more convex than the right; the greatest convexity in both valves is above the middle. Hinge line straight on the posterior side of the beak, turning abruptly downward in front; entire length greater than the length of the shell. Beaks obtuse, rounded, inclined forward, situated at the anterior third of the shell, that of the left valve quite prominent. Umbonal region of left valve prominent, subtending an acute angle. Ear triangular, nearly equilateral, with a strong angular fold along the middle, separated from the body of the valve by a distinct rounded sulcus and broad byssal sinus; margin rounded; extremity obtuse. Wing triangular, flat, limited by the postumbonal slope; margin concave; extremity acute. Test thin, marked with distinct concentric striæ of growth, which are crowded and conspicuous on the wings. There are often obscure traces of radii, which are more distinct on the wing in casts or exfoliated specimens. Ligamental area narrow, with a single distinct groove. Some specimens apparently indicate the existence of an oblique lateral tooth on the posterior side of the umbo.

The writer's specimen is smaller than those described by Hall, the height of the shell being only 5 millimeters and the length of the hinge line 6 millimeters.

Distribution.-Cumberland, Md.

Genus PANENKA Barrande.

Panenka cf. Dichotoma Hall.

Plate VII, figure 17.

1883. Cardiola? dichotoma. Hall, Nat. Hist. New York, Paleontology, vol. 5, pt. 1, Lamellibr. (adv. copy), 1883, pl. 70, fig. 21.

1885. Panenka dichotoma. Hall, Nat. Hist. New York, Paleontology, vol. 5, pt. 1, Lamellibr., pt. 2, 1885, p. 416, pl. 70, fig. 21; pl. 94, fig. 13.

1906. Panenka dichotoma. Grabau, Bull. New York State Mus. No. 92 (Fifty-eighth Ann. Rept., vol. 3, for 1904), 1906, p. 326.

The collection contains two specimens, which are probably identical with $P$. dichotoma, but owing to some imperfection in the material its identity can not be stated with certainty. Shell broadly ovate in outline, moderately convex in the anterior portion, depressed convex in the posterior portion. Surface marked by about 35 strong narrow radii in the anterior portion which become very broad and flattened in the posterior portion. Some of these on the posterior half of the shell split into three flattened radii near the center margin of the shell. Fine concentric striæ cross the radii.

Distribution.-Ridgeville, Va., and Oldtown, Md.

1 Natural history of New York, Paleontology, vol. 5, pt. 1, Lamellibr., pt. 1, 1884, pp. 158-159, pl. 17, figs. $5-11 ; \mathrm{pl} .20$, fig. 5 . 
Panenka ef. multiradiata Hall.

1883. Cardiola radians (pars). Hall, Nat. Hist. New York, Paleontology, vol. 5, pt. 1 (adv. copy), 1883, pl. 69, fig. 5 [non figs. 6-11].

1885. Panenka multiradiata. Hall, Nat. Hist. New York, Paleontology, vol. 5, pt. 1, Lamellibr., pt. 2, 1885, p. 417, pl. 69, fig. 5; pl. 94, fig. 18.

The collection contains one specimen which bears considerable resemblance to this species. The beak, however, appears to be much less prominent.

Distribution.-Blair County, Pa.

\section{Panenka alternata Hall.}

1885. Panenka alternata. Hall, Nat. Hist. New York, Paleontology, vol. 5, pt. 1, • Lamellibr., pt. 2, 1885, p. 416, text fig. p. 562.

1909. Panenka alternata. Stauffer, Bull. Ohio Geol. Survey, 4th ser., No. 10, 1909, pp. 166, 181.

This species is represented in the collections by a single specimen having about the same size as the one figured by Hall. It occurs in association with three other specimens of Panenka in a dark, slightly calcareous shale.

Distribution.-Oldtown, Md.

\section{GASTROPODA.}

\section{Genus PLATYostoma Conrad.}

\section{Platyostoma cf. euomphaloides Hall.}

1876. Cf. Platyostoma euomphaloides. Hall, Illus. Dev. Foss., 1876, pl. 9.

1879. Cf. Platyostoma euomphaloides. Hall, Nat. Hist. New York, Paleontology, vol. 5, pt. 2, 1879, p. 25, pl. 10, figs. 27-29.

A crushed specimen bearing considerable resemblance to this species occurs in the collection.

Distribution.-Cumberland, Md.

\section{Platyostoma turbinata Hall.}

\section{Plate VIII, figure 12 .}

1861. Platyostoma turbinata. Hall, Fourteenth Rept. Now York State Cab. Nat. Hist., 1861, p. 106.

1879. Platyostoma turbinata. Hall, Nat. Hist. New York, Paleontology, vol. 5, pt. 2, 1879, p. 27, pl. 9, figs. 12-24.

This species is represented by four specimens, all from a single locality, where it is rather common in one of the thin bands of dark limestone. The specimen figured is the largest of the four as well as the most completely exfoliated. These specimens represent the type of the shell with elevated spire. The surface is marked by fine transverse striæ which make an abrupt retral bend on the $20495^{\circ}-$ Bull. 508-12-7 
periphery of the last volution. No revolving striæ are preserved except a fine, threadlike line marking the retral angle of the transverse striæ on the periphery of the outer volution. Hall ${ }^{1}$ has described this species as follows in part:

Shell, subturbinate, sometimes approaching a subglobose form. Spire depressed, or more or less elevated above the outer volution, sometimes nearly on the same plane; volutions three or four, rapidly expanding, the last extremely ventricose, with the lower part projected in the direction of the columella, which is much extended. Aperture subovate, broader above, narrowing and often extended bellow. Surface marked by fine subequal concentric striæ, crossed by fine revolving striæ; thice former variously undulated upon the surface, indicating sinuosities in the aperture at different stages of growth. In older shells the striæ become lamellose and often crowded: in fascicles.

Distribution,-McVeytown, Pa.

\section{Platyostoma lineata Hall.}

1842. Platyostoma lineata. Conrad, Jour. Acad. Nat. Sci. Philadelphia, vol. 8, 1842, p. 276 , pl. 17, fig. 7 .

1879. Platyostoma lineata. Hall, Nat. Hist. New York, Paleontology, vol. 5, pt. 2, 1879, p. 21, pl. 10, figs. 1-21.

This species is represented by a small partly exfoliated shell 6 millimeters in diameter. It has been described by Hall ${ }^{2}$ as follows:

Shell subovate, approaching to subglobose. Spire elevated above the body whorl, ! though varying in degree; in some extreme varieties, on the same plane or below the outer volution.

The shell with four or five volutions when entire, but seldom preserving more than three, the apex being usually imperfect, the outer volution usually very ventricose and regularly convex, a little depressed below the suture line (but not caniculate). A perture suborbicular in perfect specimens, sometimes subrhomboidal outer lip thin, with sharp entire margin; columellar lip thickened; folded, and reflexed over the umbilicus, which in adult specimens is entirely closed.

Surface marked by firie, equidistant threadlike revolving striæ, which are cancellated by fine concentric striæ of about the same strength, but unequally distant; the latter sometimes bend abruptly backward upon the back of the shell, indicating a sinus in the lip at some period of growth and are frequently crowded in fascicles, giving a rugose character to the surface.

Distribution.-Blair County, Pa.

\section{Genus NATICOPSIS McCoy:}

Naticopsis sp. undet.

Plate VIII, figure 11.

Casts of a small species of Naticopsis of undetermined identity occur in the dark shale at some localities.

Distribution.-Blair County, Pa.; Ridgeville, W. Va.; and Cumberland, $\mathrm{Md}$.

1 Natural history of New York, Paleontology, vol. 5, pt. 2, 1879, p. 27.

2 Idem, p. 21. 


\section{Genus PLATYCERAS Conrad.}

\section{Platyceras thetis Hall.}

Plate VIII, figure 13.

1862. Platyceras thetis. Hall, Fifteenth Rept. New York State Cab. Nat. Hist., 1862, p. 32.

1879. Platyceras thetis. Hall, Nat. Hist. New York, Paleontology, vol. 5, pt. 2, 1879. p. 8, pl. 3, figs. 11-16.

This species is represented in the collection by a single specimen, which is here figured. The erect portion of the shell has been distorted and flattened by pressure. The description of the species, as given by Hall, ${ }^{1}$ is as follows:

Shell obliquely arcuate from the base, with the apex incurved, the nu ?leus making barely more than a single minute volution; gradually expanding from the apex to near the aperture, which is sometimes more abruptly spreading. The back of the body whorl is prominent, and a little flattened on the left side, while the right side from one-third to one-half the length is sometimes marked by two or three longitudinal folds, and often by more numerous, finer plications. Aperture a little oblique, nearly round or subquadrangular, with the peristome sinuous.

Surface marked by fine, closely arranged lamellose striæ, which are abruptly undulated on all parts of the body of the shell. In many, and perhaps nearly all, specimens the body of the shell along a line a little to the left of the dorsum is marked by an abrupt curvature of the striæ, indicating a notch in the margin of the peristome. This line is sometimes marked by a narrow prominent band not unlike that of Pleurotomaria.

Distribution.-New Bloomfield, Pa.

\section{Platyceras cf. rictum Hall.}

1862. Cf. Platyceras rictum. Hall, Fifteenth Rept. New York State Cab. Nat. Hist., 1862, p. 35.

1879. Cf. Platyceras rictum. Hall, Nat. Hist. New York, Paleontology, vol. 5, pt. 2, 1879 , p. 13, pl. 4, figs. 6, 12-17.

A small depressed shell, which may be a young specimen of this species, is found in one of the collections. The nucleus is very small, outer whorl abrupt and broadly expanded. Surface marked by fine transverse undulating striæ.

Distribution.-Schuylkill Haven, Pa.

\section{Platyceras sp. undet.}

The collection includes a third species of Platyceras, represented by fragmentary material. The shell is strongly arcuate with regular transverse striæ; aperture 16 millimeters in diameter.

Distribution.-Clifton Forge, Va.

1 Natural history of New York, Paleontology, vol. 5, pt. 2, 1879, p. 8. 
Genus LOXONEMA Phillips.

\section{LOXONEMA HAMILTONis Hall.}

Plate VIII, figures 9-10.

1862. Loxonema hamiltonis. Hall, Fifteenth Rept. New York State Cab. Nat. Hist., 1862 , p. 53.

1879. Loxonema Hamiltonix. Hall, Nat. Hist. New York, Paleontology, vol. 5, pt. 2, 1879, p. 45, pl. 13, figs. 15, 17.

This species has been described by Hall ${ }^{1}$ as follows:

Shell elongate, subulate. Volutions moderately convex, about thirteen in the largest specimens known, very gradually increasing in size from the minute apex, the last one ventricose. Aperture ovate, narrowing below; columella extended. Surface marked by longitudinal, sharp, curving striæ, which bend gently backward from the suture, and forwards toward the base of the volution, having the greatest curve near'the middle, those of the last volution curving abruptly backward to the columellar lip. Striæ separated by distinctly defined grooves which are a little wider than the ridges; the striæ increasing in distance as the shell grows older.

The specimens in the collection are all preserved in soft shales and somewhat flattened. The largest specimen observed has fourteen volutions and a length of nearly 2 inches. Average specimens have from 10 to 13 volutions.

Distribution.-Blair County, Pa.; Cumberlard, Md.; Ridgeville, W. Va.

\section{LoXonema cf. PEXATA Hall.}

1861. Cf. Loxonema pexata. Hall, Fourteenth Rept. New York State Cab. Nat. Hist., 1861, p. 104.

1879. Cf. Loxonema pexata. Hall, Nat. Hist. New York, Paleontology, vol. 5, pt. 2, 1879 , p. 42 , pl. 13 , figs. $16,18(11,12)$ ?

The loxonemas from one of the localities are all smaller, less elongate, and with less than half the volutions seen in $L$. hamiltonix. The specimens probably represent $L$. pexata. The species hàs been described by Hall ${ }^{2}$ as follows:

Shell elongate, terete or subfusiform. Volutions six or more, gradually expanding from the apex, somewhat flattened on the upper half, or a little concave just below the suture, and most convex below the middle; the last one moderately ventricose. Aperture subelliptical. Surface marked by strong, regular, elevated striæ, which cross the volutions in a gentle curve, turning backward from the suture and again forward, making the curve at about one-third of the distance from the upper side of the volution. On well-preserved specimens the striæ are sharply elevated, but are subject to considerable variation, which may be due to erosion or maceration before embedding.

Distribution.-Blair County, Pa., 2 miles west of Canal Creek. 


\section{Genus BELLEROPHON Montfort.}

Bellerophon sp. undet.

One of the specimens in the collection exhibits features of surface sculpture which I have not been able to identify with any described species, although it may represent a variety of Bellerophon leda. Surface marked by fine revolving striæ, 12 or more to a millimeter. Dorsal band without any elevation, with traces of indistinct revolving striæ limited by two threadlike striæ similar to the other revolving striæ on either side. Surface marked by lines of growth which make a strong retral curve in crossing the dorsal band.

Distribution.-Blair County, Pa.

\section{Belllerophon leda Hall.}

Plate VIII, figure 14.

1862. Bellerophon leda. Hall, Fifteenth Rept. New York State Cab. Nat: Hist., 1862, p. 58.

1879. Bellerophon leda. Hall, Nat. Hist. New York, Paleontology, vol. 5, pt. 2, 1879 , p. 110, pl. 23, figs. 2-16.

The few specimens of this species which have been observed are all much smaller than those figured by Hall. They are too fragmentary to show much more than the characteristic surface markings of the species. These include strong revolving striæ cancellated by nearly equally strong transverse striæ; a narrow concave and moderately elevated dorsal band. In crossing this the transverse striæ make an abrupt retral curve.

The following description of the species is drawn from Hall. ${ }^{1}$

Shell subglobose, often a little flattened upon the dorsum; body whorl ventricose, very rapidly expanding. Aperture abruptly spreading, broadly sinuate in front and sometimes with a deeper notch in the middle, the margin gently recurved, joining the volution a little on the ventral side, where it is thickened, somewhat abruptly curving over and partially inclosing the small umbilicus, and extends in a callus over the columellar lip, which is sometimes distinctly striato-pustulose.

Surface marked by strong longitudinal or revolving striæ, which alternate in size, are sometimes fasciculate, and often finer and more numerous on each side of the dorsal band than on the lateral portions of the shell. The revolving strix are cancellated by finer, subequal, threadlike transverse striæ. The dorsal band is narrow, rarely elevated or sometimes scarcely raised above the surface, and usually flat or slightly concave, the concentric striæ making an abrupt retral curve upon it in crossing. The band is likewise usually marked by one, two, three, or more revolving striæ finer than those on the sides of the shell, and sometimes quite obscure.

Distribution.-Schuylkill Haven, Pa., and Bells Valley, Va. 


\section{Bellerophon PELOPS Hall.}

1862. Bellerophon (Bucania) pelops. Hall, Fifteenth Rept. New York State Cab. Nat. Hist., 1862, p. 56.

1879. Bellerophon pelops. Hall, Nat. Hist. New York, Paleontology, vol. 5, pt. 2, 1879, p. 95, pl. 22, figs. 7-13.

In the collection this shell is represented only by casts of the interior and fragments of the exterior markings. The latter are too fragmentary for figuring, but clearly indicate this species by their correspondence to Hall's figures and original description, which follows.

Casts of this species occur in the limestone of the Upper Helderberg group.

The shell has been very rotund: the volutions, which have been three or four, were exposed in the umbilicus; the transverse diameter of the volution is about twice as great as the length or dorso-ventral diameter, rounded on the back, and abruptly bent into the umbilicus; the aperture expands laterally, and is somewhat reniform, with a sinus on the dorsal side; the back is distinctly carinate on the last volution, and the surface has apparently been marked by transverse striæ.

It is impossible to characterize the species fully from the materials possessed, but it may be distinguished by its similarity of form to $B$. expansus; but the dorsal carina on the crest of this one is more sharply marked, the volutions are less compressed in the dorso-ventral direction, and the umbilicus is more abruptly depressed.

Distribution.-Blair County, $\mathrm{Pa}$.

\section{Genus PLEUROTOMARIA De France.}

\section{Pleurotomaria cf. trilix Hall.}

1862. Cf. Pleurotomaria trilix. Hall, Fifteenth Rept. New York State Cab. Nat. Hist., 1862 , p. 45 , pl. 5 , fig. 1.

1879. Cf. Pleurotomaria trilix. Hall, Nat. Hist. New York, Paleontology, vol. 5, pt. 2,1879 , p. 79 , pl. 21, figs. 13-15.

Fragmentary and crushed material representing a single specimen bears some resemblance to this species. It is too incomplete, however, to be more than suggestive of the identity of the form represented.

Distribution.-Clifton Forge, Va.

\section{Pleurotomaria crassa n. $\mathrm{sp}$.}

Plate VIII, figures $7,8$.

The description of this species is of a single, somewhat fragmentary specimen which, however, shows in its surface sculpturing very distinctive specific characters.

Shell turbinate; spire erect, apparently higher than wide. Volutions about four, subangular on the periphery.

Surface marked by a revolving carina above and below the peripheral band on the second volution. Strong angular transverse striæ separated by spaces equal to twice their width cross these, making nodelike crenulations. These transverse lines swing sharply back- 
ward away from the aperture in approaching the slit band. The first volution has one revolving carina above the slit band and two below it. The two lower ones are placed near together, resembling a second peripheral band. The transverse lines in approaching these from the umbilicus are directed anteriorly, but cross them nearly at right angles, then swing backward to the peripheral band.

This shell resembles $P$. sulcomarginata in its strong, coarse sculpturing, but is distinguished from that species by having two carina instead of one below the peripheral band of the first volution.

Distribution.-Blair County, Pa., 2 miles west of Canoe Creek.

\section{PTEROPODA:}

\section{Genus STYLIOIINA Karpinisky.}

\section{Strliolina fissurella Hall.}

1843. Tentaculites fissurella. Hall, Geology New York, Survey Fourth Geol. Dist., 1843 , p. 180 , figs. 9 , 10 ; p. 222 , fig. 4.

1879. Styliola fissurella. Hall, Nat. Hist. New York, Paleontology, vol. 5, pt. 2, 1879, p. 178, pl. 31A, figs. 1-30.

These minute shells occur in great abundance in dark or drab shales at a few localities. Their average length is about 3 millimeters.

Distribution.-Blair County, Pa.; Cumberland, Md.; Sassin and Bells Valley, Va.

\section{Genus TENTACULITES Schlotheim.}

\section{Tentaculites gracilistriatus Hall.}

Plate IX, figure 4.

1879. Tentaculites gracilistriatus. Hall, Nat. Hist. New York, Paleontology, vol. 5, pt. 2,1879 , p. 173, pl. 31, figs 12, 13; pl. 31A, figs. 37-47.

This shell occurs in about the same abundance as the preceding and is associated with it. It is distinguished from Styliolina fissurella by its annulated and longitudinally striated surface.

Distribution.-Same as the preceding species.

\section{Tentaculites scalariformis Hall.}

Plate IX, figure 5 .

1876. Tentaculites scalariformis. Hall, Illus. Dev. Foss., 1876, pl. 26, figs. 3-11.

1879. Tentaculites scalariformis. Hall, Nat. Hist. New York, Paleontology, vol. 5, pt. 2, 1879, p. 167, pl. 31, figs. 3-11.

This specimen is represented in the collection by a single fragmentary individual. It is of the type represented in figures 3, 5, and 11 by Hall, ${ }^{1}$ suggesting a series of minute nested cups with pro- 
jecting rims. The posterior slope of the annulations is abrupt, and the anterior slope is more gentle. Four or five very fine transverse striæ mark the interval between each pair of annulations. The description of the species as given by Hall is as follows:

Form elongate conical, straight, somewhat more cylindrical in approaching the aperture; with the apex in well-preserved specimens extremely attenuate and quite solid from one-fourth to one-third the entire length of the shell. Annulations prominent, subangular, sometimes rounded on the larger part of the cone, closely arranged and sharply angular near the apex, gradually increasing their distance, becoming less angular with the increase in the size of the.shell, and obtuse and rounded toward the aperture; usually but little variation in character on the outer half of the length, where the spaces between are greater than the annulations. Interspaces and annulations, when well preserved, marked by fine, even transverse striæ, of which 9 or 10 may be counted in the furrows, and half as many on the summit and sides of the annulations.

Distribution.-Mendota, Va.

Tentaculites cf. Bellulus Hall.

1876. Cf. Tentaculites bellulus. Hall, Illus. Dev. Foss., 1876, pl. 26, figs. 15-18.

1879. Cf. Tentaculites bellulus. Hall, Nat. Hist. New York, Paleontology, vol. 5, pt. 2, 1879, p. 169, pl. 31, figs. 15-18; pl. 31A, figs. 48-51.

A few fragmentary specimens appear to represent this species. They show very prominent angular annulations of symmetrical type. Fifteen to twenty fine transverse striæ mark the angular interspace between each pair of these, extending up their sides nearly to their crests.

Distribution.-Schuylkill Haven, Pa.

\section{Genus BACTRITES G. Sandberger.}

\section{Bactrites aciculum Hall.}

Plate IX, figure 3.

1843. Orthoceras aciculum. Hall, Geology of New York, Survey Fourth Geol. Dist., 1843, p. 243.

1879. Coleolus aciculum. Hall, Nat. Hist. New York, Paleontology, vol. 5, pt. 2, 1879 , p. 187, pl. 32A, figs. 11-15 (16?).

This fossil occurs on the surface of slabs of dark or drab shaleas flattened acicular cones destitute of surface markings.

Distribution.-Cumberland, Md.; Hollidaysburg, Pa.; and Sas$\sin$, Va.

\section{Bactrites of. Tenuicinctum Hall.}

1876. Cf. Coleoprion tenuicinctum. Hall, Illus. Dev. Foss., 1876, pl. 27, figs. 1-4.

1879. Cf. Coleolus tenuicinctum. Hall, Nat. Hist. New York, Paleontology, vol. 5, pt. 2,1879, p. 185 , pl. 32 , figs. 5-9; pl. 32A, figs. 6-10.

A single small fragmentary specimen appears to be referable to this species.

Distribution.-Mendota, Va. 


\section{Genus COLEOLUS Hall.}

\section{Coleolus? curvatus n. sp.}

Plate IX, figures 1, 2.

Shell small, tubular, tapering regularly to the acicular extremity. Gently and regularly curved; surface smooth. Average specimen has a length of 10 millimeters and a diameter at the aperture of $1 \frac{1}{2}$ millimeters. This shell is closely allied to Coleolus gracilis but is rather more strongly curved and tapers more rapidly. Coleolus gracilis is also supposed to be transversely striate, while this species is smooth.

This small Dentalium-like shell has been observed at but one locality, where it is abundant in a soft drab shale.

Distribution.-Blair County, $\mathrm{Pa}$., in road 2 miles west of Canoe Creek.

\section{Genus HYOLITHES Eichwald.}

\section{Hyolithes cf. ACLIS Hall.}

1876. Cf. Hyolithes aclis. Hall, Illus. Dev. Foss., 1876, pl. 27, figs. 5, 6, 7, 10, 11.

1879. Cf. Hyolithes aclis. Hall, Nat. Hist. New York, Paleontology, vol. 5, pt. 2 , 1879 , p. 197, pl. 32 , figs. 22-30; pl. 32A, figs. 23-25.

The collections contain two small specimens in a poor state of preservation which are comparable to this species and may belong to it.

Distribution.-Blair County, Pa., and Ridgeville, W. Va.

\section{Hrolithes cf. PRINCIPALIS Hall.}

1876. Cf. Hyolithes principalis. Hall, Illus. Dev. Foss., 1876, pl. 27, figs. 17-20.

1879. Cf. Hyolithes principalis. Hall, Nat. Hist. New York, Paleontology, vol. 5, pt. 2, 1879, p. 196, pl. 32, figs. 17-21.

The collections contain a single specimen, which although fragmentary shows marked resemblance to this species. The specimen exhibits rapidly tapering sides and has a maximum breadth of 13 millimeters. Neither the anterior nor the posterior extremities of the shell are preserved.

Distribution.-Occurs in drab shale in Blair County, Pa.

Genus ENCHOSTOMA Miller and Gurley.

\section{Enchostoma?'sp.}

The collection contains specimens of a cylindrical rodlike fossil about a millimeter in diameter occurring in an earthy limestone. The specimens represent only fragments rather less than an inch in length, composed of hard chitaneous material. That these have had considerable length is indicated by the barely perceptible 
amount of tapering seen in the individual specimens. Provisionally they may be referred to Enchostoma.

Distribution.-Cumberland, Md.

\section{Genus CONULARIA Miller.}

Conularia sp. undet.

The collection includes six fragmentary specimens of Conularia representing different localities. These are all more or less completely flattened, making specific determination uncertain. One of the specimens at least is comparable and probably identical with C. undulata.

Distribution.-Cumberland, Md., and Mountain Grove, Va.

\section{CEPHALOPODA.}

\section{Genus ORTHOCERAS Breynius.}

Orthoceras cf. subulatum Hall.

1843. Cf. Orthoceras subulatum. Hall, Geology of New York, Survey Fourth Geol. Dist., 1843, p. 180, fig. 1.

1879. Cf. Orthoceras subulatum. Hall, Nat. Hist. New York, Paleontology, vol. 5, pt. 2 , 1879 , p. 283 , pl. 38 , fig. 3 ; pl. 84 , figs. $1,2,4,6-10$; pl. 86, figs. $1,2$.

The collection contains a few small fragmentary specimens of an Orthoceras which, so far'as the poor quality of the material permits of study, are comparable with Orthoceras subulatum.

Distribution.-Blair County, Pa., and Cumberland, Md.

Genus PAROdiceras Hyatt.

\section{Parodiceras discoideum (Conrad).}

1860. Goniatites discoideus. Hall, Thirteenth Rept. New York State Cab. Nat. Hist., 1860 , p. 97 ; figs. 4-6, p. 98 .

1879. Goniatites discoideus. Hall, Nat. Hist. New York, Paleontology, vol. 5, pt. 2, 1879, p. 441, pl. 71. figs. 1-13; pl. 74, figs. 4-5.

This is a rare species, having been recognized at but one locality, where it is represented by fragmentary material. It is possible, moreover, that the faunule with which this species is associated is of Marcellus instead of Onondaga age.

Distribution.-Sassin, Va. 
Genus AGONIATITES Meek.

\section{Agoniatites expansus (Vanuxem).}

Plate IX, figure 6.

1842. Goniatites expansus. Vanuxem, Geology of New York, Survey Third Geol. Dist., 1842, p. 146, fig. 1.

1879. Goniatites vanuxemi. Hall, Nat. Hist. New York, Paleontology, vol. 5, pt. 2, 1879, pp. 434-438, pls. 66-69, figs. 3-6; pl. 109, figs. 7-8.

This shell occurs in beds near the top of the Onondaga shale. The specimen figured has a maximum breadth of 47 milimeters and represents an individual of average size. The surface is covered with striæ having the direction shown in the figure. The septa are not preserved in the specimens observed. None of these approach in size some of the specimens of $A$. expansus figured by Hall.

Distribution.-Blair County, Pa.; Cumberland and Twenty-first Bridge, Md.

\section{TRILOBITA.}

\section{Genus PHACOPS Emmrich. \\ Phacops Rana (Green). \\ Plate $\mathrm{X}$, figures $1-5$.}

1832. Calymene bufo var. rana Green, Mon. Trilobites North America, 1832, p. 42.

1861. Phacops rana. Hall, Desc. New Sp. Fos., 1861, p. 65.

1862. Phacops rana. Hall, Fifteenth Rept. New York State Cab. Nat. Hist., 1862, p. 93, pl. 10, fig. 12.

This long-ranging species is represented by several specimens, which agree in all essential features with $P$. rana as it appears in the Hamilton. The simple annulations of the pygidium and the absence of genal spines distinguish them from $P$. cristata var. pipa. In New York this trilobite ranges more than a thousand feet above the top of the Hamilton; but its presence there in the Onondaga has been reported doubtfully.

Distribution.-Bells Valley, Va., and New Bloomfield, Pa.

\section{Phacops cristata Hall.}

Plate X, figures 6-8.

1861. Phacops cristata. Hall, Desc. New Sp. Fos., 1861, p. 67.

1888. Phacops cristata. Hall and Clarke, Nat. Hist. New York, Paleontology, vo.. 7, 1888, p. 14, pl. 6, figs. 1-31, 16-29; pl. 8A, figs. 1-4.

This species and the related form $P$. cristata var. pipa are probably the most abundant representatives of the trilobites in this fauna. Although $P$. cristata is readily distinguished from $P$. cristata var. pipa by tho axial row of spines and other less conspicuous differences in 
perfect specimens, the two are often difficult to discriminate in the fragmentary material representing them in the average collection. The g]abella figured is that of the largest individual observed, having a length and breadth, respectively, of 18 and 24 millimeters. The genal spines, though not shown in the figure, are indicated by , broken bases in the specimen.

Distribution.-Schuylkill Haven, Pa.; Alinda and New Bloomfield, Perry County, Pa.; Berkeley Springs and Ridgeville, W. Va.; Clifton Forge, Va.

Phacops cristata var. pipa Hall and Clarke.

Plate X, figures 9, 10.

1888. Phacops cristata var. pipa. Hall and Clarke, Nat. Hist. New York, Paleontology, vol. 7, 1888, p. 18, pl. 8A, figs. 5-18.

This species is often not easily distinguished from the preceding. It appears to be represented in the collections by numerous pygidia. It is probably a common species, but the difficulty of distinguishing specimens of this species without nearly perfect material from $P$. rana and $P$. cristata leaves the determination of fragmentary remains doubtful in many instances.

Distribution.-New Bloomfield, Alinda, Hollidaysburg, Pa.; Poplar Hill, Clifton Forge, and Mendota, Va.

\section{Genus CRYPHAUS Green.}

Cryphaus ef. boóthi var. calliteles (Kayser).

Plate X, figures 14, 15; Plate XI, figure 1.

1878. Cf. Cryphæus calliteles?. Kayser, Abhandl. z. Geol. Specialkarte von Pr. u. d. Thur. St., vol. 2, pt. 4, 1878, p. 32, pl. 3, fig. 10.

1888. Cf. Dalmanites (Cryphæus) Boothi var. Calliteles. Hall and Clarke, Nat. Hist. New

York, Paleontology, vol. 7, 1888, p. 45, pl. 16, figs. 5-22; pl. 16A, figs. 9-17.

The specimens referred provisionally to this species represent the glabella and a portion of the thorax of five individuals. The pearshaped glabella varies in length from 4 to 8 millimeters and shows three posterior lateral furrows. A conspicuous tubercle marks the axis of the occipital ring. The best of this fragmentary material is shown in the figures.

Distribution.-Ridgeville, W. Va.; Blair County and New Bloomfield, Pa. 
Genus DaImanites Emmerich.

\section{Dalmanites (Coronura) aspectans (Conrad)?.}

Plate $\mathrm{X}$, figures 12, 13.

1841. Cf. Asaphus aspectans. Conrad, Fifth Ann. Rept. Geol. Survey New York, 1841, p. 48 , fig. 9 .

1888. Cf. Dalmanites (Coronura) aspectans. Hall and Clarke, Nat. Hist. New York, Paleontology, vol. 7, 1888, p. 33, pl. 13, figs. 1-11, 13.

The specimens here provisionally referred to this species comprise two pygidia, two cephalons, and a detached eye, all from one locality, and one bed of argillaceous limestone. They are too fragmentary to permit certain identification with $D$. aspectans, but the features preserved are so strikingly like those of that species as to leave little doubt of their identity. They show the strongly tuberculose character of the cephalon, the great number of eye facets, and the tuberclecovered pygidium characterizing ' $D$. aspectans. A portion of the eye is not exposed, but about 250 corneal lenses may be counted on the portion that is visible.

Distribution.-Frankstown, Pa., station 32a.

\section{Genus ODONTOCEPHALUS Conrad.}

\section{Odontocephalus SELENURUS (Eaton).}

Plate XII, figure 6.

1832. Asaphus selenurus. Eaton, Geol. Text Book, 1832, p. 31, pl. 1, fig. 1.

1835. Calymene? odontocephala. Green, Mon. Trilobites North America, Sup., 1835, p. 9. 1876. Dalmanites selenurus. Hall, Illus. Dev. Foss. Crust., 1876, pl. 12, figs. 12-14.

1888. Dalmanites (Odontocephalus) selenurus. Hall and Clarke, Nat. Hist. New York,

Paleontology, vol. 7, 1888, p. 49, pl. 11B, figs. 15-21; pl. 12, figs. 1-13.

This species appears to be much less common than the closely related species $O$. æxgeria. It is represented by a pygidium and the anterior or border of a cephalon, both from the same locality. The latter has but eight or nine of the incisor-like processes on its anterior margin instead of the eleven processes which usually characterize O. xgeria. The terminal spines of the pygidium are inclined distinctly upward. There are nine annulations on the pleura, with indications of a tenth.

Distribution.-Occurs in black limestone at Falling Spring, on Sherman Creek, Perry County, Pa.

\section{Odontocephalus ageria Hall.}

Plate X, figure 11; Plate XI, figures 3-5; Plate XII, figures 1-5, 7, 8.

1861. Dalmania ægeria. Hall, Desc. New Sp. Foss., 1861, p. 57.

1862. Dalmania ægeria. Hall, Fifteenth Rept. New York State Cab. Nat. Hist., 1862, p. 85.

1868. Dalmanites (Odontocephalus) xgeria? Meek and Worthen; Geol. Illinois, vol. 3, 1868, p. 417, pl. 10, figs. 4 a, b, c. 
1876. Dalmanites ægeria. Hall, Illus. Dev. Foss. Crust., 1876, p. 12, figs. 3, 6, 8 [not figs. 1, 2, 7].

1888. Dalmanites (Odontocephalus) xgerna. Hall and Clarke, Nat. Hist. New York, Paleontology, vol. 7, 1888, p. 53, pl. 11B, figs. 1-11.

The collection includes, besides numerous pygidia and fragments of the cephalon, four nearly complete individuals of this species. The largest of these has a length of 86 millimeters. Comparison of these with the published description of the species and the types, ${ }^{1}$ though clearly indicating identity with $O$. æxeria, shows some previously undescribed features of the thoracic segments which could not be observed in the types. Hence the thorax and pygidium are here ibriefly described without specific reference to the anterior portion of the trilobite.

The thorax comprises 10 segments. The pleura are broad and conspicuously sulcate. They are flattened along their inner or proximal half and are abruptly deflected downward at the fulcrum. At the distal extremity they terminate in trowel-like or lanceolate processes, which are deflected backward, forming a fimbriate border, and which have a length of 2 to 5 millimeters in the specimens observed. These fimbriæ are concealed anteriorly, if present, by the genal spines, which extend to or beyond the middle of the thorax. The terminal process on the last pleuron of the thorax extends backward to the third segment of the pygidium on one specimen.

Through the courtesy of Dr. J. M. Clarke and the curator of the American. Museum of Natural History, Dr. E. O. Hovey, I have been able to compare my specimens with the types. The only one of the type specimens exhibiting the thoracic portion of the species evidently represents an immature individual and is about one-third the size of some of my specimens of this species. The thoracic fimbria would therefore scarcely be likely to be so prominently developed as on the fossils here figured. Examination of the type specimen, however, showed distinctly the presence of these posteriorly directed tips, which have been partly broken away, with the limestone matrix on four of the pleura adjacent to the pygidium on one side of the trilobite.

The annulations on the pleura of the pygidium, as shown both by the types and the Pennsylvania specimens, are entirely without these terminal processes. The ten or eleven annulations on the pygidium terminate on a smooth, gently rounded border. The axis has ten distinct and two or more indistinct annulations. Examination of the pygidia of the types, two of which are well preserved, fails to disclose any indication of the double axial row of tubercles on the axis,

1 Specimens 4258-4260, catalogue type specimens of Paleozoic fossils in Bull. New York State Mus. No. 65, 1903, p. 679 . Specimen 4067, catalogue of types, Bull. Am. Mus. Nat. Hist., vol. 11, pt. 3, 1900, p. 342. 
which is said to be one of the distinguishing features of this species. ${ }^{1}$ It may be, therefore, that they characterize a species distinct from 0 . $x$ geria. In the number of pleura on the pygidium the types show some differences. The original of Hall and Clark's figure 3, plate $11 \mathrm{~B},{ }^{1}$ has but nine pleura and eight annulations on the axis, whereas the other two of the types examined have each eleven pleura and nine annulations. The smaller number belongs to a much smaller individual and hence may be attributable to immaturity. In my collection the usual number of annulations on the pygidium is ten or eleven. One specimen, however, shows eleven, with traces of two others.

Distribution.-Alinda, New Bloomfield, and Blair County, Pa., and Clifton Forge, Va.

\section{Genus PHATHONIDES Angelin.}

Phethonides gemmaeus Hall and Clarke.

Plate XIII, figures 11,12 .

1888. Phæthonides gemmæus. Hall and Clarke, Nat. Hist. New York, Paleontology, vol. 7,1888 , p. 136, pl. 24, figs. $32-36$.

This species is represented by a portion of a pygidium having a length of about 3 millimeters: The comparatively small posterior limb of each annulation terminates at the inner margin of the broad, somewhat flattened border, whereas the anterior limb extends beyond the border and terminates in a spine. From four to six blunt spines or tubercles mark the surface of each anterior limb of the annulations.

Distribution.-Mendota, Va.

\section{Genus CONOLICHAS Damer.}

Conolichas cf. hispidus Hall and Clarke.

1876. Cf. Acidaspis (Teratapsis) Eriopsis. Hall, Illus. Dev. Foss., 1876, pl. 19, figs. 8, 9. 1888. Cf. Lichas (Conolichas) hispidus. Hall and Clarke, Nat. Hist. New York, Paleontology, vol. 7, 1888, p. 77, pl. 19A, figs. 14, 17, 18.

The collection contains one imperfect pygidium which probably belongs to this species.

Distribution.-Ridgeville, W. Va.

\section{Genus CYPHASPIS Burmeister.}

Cyphaspis cf. stephanophora Hall and Clarke.

Plate XIII, figure 2.

1888. Cf. Cyphaspis stephanophora. Hall and Clarke, Nat. Hist. New York, Paleontology, vol. 7, 1888, p. 142, pl. 24, figs. 2-6.

The specimens which are closely related to if not identical with this species include a glabella and one of the free cheeks. They occur in a 
soft, blocky black shale. Their appearance is sufficiently indicated by the figures.

Distribution.-Berkeley Springs, W. Va.

\section{Genus LICHAS Dalman.}

Lichas (Arges) contusus Hall and Clarke var.

Plate XIII, figure 1.

1888. Cf. Lichas (Arges) contusus. Hall and Clarke, Nat. Hist. New York, Paleontology, vol. 7,1888 , p. 83 , pl. 19B, figs. 3-6.

This species is represented by a single glabella. It does not differ very materially from the specimens figured by Hall and Clarke except in its much smaller size. The length of the specimen figured is only 2 millimeters.

Distribution.-Mendota, Va.

\section{Genus ACIDASPIS Murchison.}

Acidaspis callicera Hall and Clarke.

Plate XIII, figures 3-10.

1888. Acidaspis callicera. Hall and Clarke, Nat. Hist. New York, Paleontology, vol. 7, 1888 , p. 69 , pl. 16B, figs. 1-13.

This small but characteristic Onondaga trilobite is represented in the collection by free cheeks, with short marginal and long genal spines, from a number of localities ranging from central Pennsylvania to southwestern Virginia. These generally show about 12 marginal spines and a strong lateral spine branching from near the base of the genal spine. Spinelike tubercles mark the upper surface. Representatives of the glabella and pygidium of this species are comparatively rare. The best specimens are shown by the figures.

Distribution.-Alinda and New Bloomfield, Pa.; Fort Seybert, W. Va.; and Mendota, Va.

\section{Genus DALMaNITES Barrande.}

\section{Dalmanites sp. undet.}

Plate XI, figure 2.

The collection includes a single cephalon (here figured) of uncertain specific affinities but somewhat resembling Dalmanites anchiops. The cephalon shows the crenulated border at the anterior margin of the glabella, the right free cheek, and the facial suture. Most of the remainder of the cephalon is wanting.

Distribution.-Rees Tannery; south of Keyser, W. Va. 
OSTRACODA. ${ }^{1}$

\title{
Genus BOLLIA Jones and Holl.
}

\section{Bollia ungula Jones.}

\author{
Plate IX, figures 9, 10.
}

1889. Bollia ungula. Jones, Am. Geologist, vol. 4, 1889, pp. 338-339, pl. opp. p. 242, figs. 10-13, 1889.

Jones's original description follows:

Prof. Claypole's specimens are well-preserved casts in buff-colored, noncalcareous shales from the Marcellus limestone of Perry County, Pa. (near New Bloomfield). There are several, and they vary from 1 to $2 \frac{1}{2}$ millimeters in length. The cproportions of some of the best are given in the figures 10 to 13 , magnified 15 diameters. In some respects they resemble Bollia lata Hall; ${ }^{2}$ but they are larger, and the central curved ridge is much thinner at its curve, whereas in the specimens from New York State the curve is thicker just there, and is not so symmetrical throughout as in the Pennsylvania specimens. Hence I prefer to regard the latter as specifically distinct, and to adopt Prof. Claypole's manuscript specific name ${ }^{3}$ (having reference to the hoof-like ridge), than to refer them to Bollia lata. A hollow cast of the outside and one presumably perfect valve give evidence of a smooth exterior.

The slight variations in the shape and proportions of the curved subcentral ridge and of the marginal ridge are well shown in the figures.

This species is one of the most abundant ostracodes found in the fauna. My collection contains numerous specimens of the species; from the type locality at New Bloomfield, which are identical in every respect with the specimens found in Maryland, Virginia, and West Virginia. The reference of the species to the Marcellus limestone by Jones is, of course, based on Claypole's opinion as to the horizon of the beds which furnished this and other ostracodes described by Jones from New Bloomfield. It is significant that all stratigraphic records of the New Bloomfield specimens made since their description places the species lower than the Marcellus shale. Ulrich ${ }^{4}$ has figured it from the horizon of the Onondaga limestone at the Falls of the Ohio, and in an unpublished paper Ulrich and Bassler have recorded it from the lower Oriskany in Maryland.

Distribution.-Hollidaysburg, New Bloomfield, McVeytown, Pa.; Cumberland and Tonoloway, Md.; Rees Tannery, south of Keyser, W. Va.; Bells Valley and Clifton Forge, Va.

\footnotetext{
1 In connection with questions of correlation, with which this paper is primarily concerned, the old and better-known species are of more interest than the new ones. The former alone will be considered. The collection contains some new species and several specimens of doubtful specific or generic identity. These new and doubtful forms will be referred to special students of this group and will not be taken up in this paper. Since the original descriptions of the figured species are widely scattered in publications not easily accessible to most students, it has seemed desirable to quote them in full.

2 Natural history of New York, Paleonto'ogy, vol. 2, 1852, p. 301, pl. A 66, figs 10a, b, d (not figs. c and e), also some in British Museum. Jones says: "I may here mention that I have to refer lata and symmetrica to Bollia, and spinosa to Achmina."

8 This name was never published by Claypole.

\Jour. Cincinnati Soc. Nat. Hist., vol. 13, 1891, p. 188, pl. 14, figs. $6 \mathrm{a}, \mathrm{b}$.
} $20495^{\circ}-$ Buil. $508-12-8$ 


\title{
BOLLIA OBESA Ulrich.
}

\author{
Plate IX, figure 8.
}

1891. Bollia obesa. Ulrich, Jour. Cincinnati Soc. Nat. Hist., vol. 13, 1891, p. 189, pl. 14, figs. 5a, b, c.

Ulrich's original description follows:

Size of valve: Length, 1.52 millimeters; height, 0.98 millimeter; thickness, 0.5 millimeter. Carapace subpentagonal, ends nearly equal, strongly curved, back straight, short, dorsal angles obtuse, ventral edge produced in the middle. Marginal portion of valves thick, causing them to appear unusually ventricose. Horseshoe ridge unsymmetrical, with bulbous extremities, the anterior knob oval and reaching the dorsal edge, the posterior one larger, more nearly round, and terminating a short distance within the dorsal margin. This species is not likely to be mistaken for any other known to me. Though clearly a true Bollia, it is very different in its general appearance from the associated $B$. ungula Jones. Position and locality: Devonian Bryozoa bed, Falls of the Ohio.

This species is associated with $B$. ungula but is less abundant.

Distribution.-Blair County, Pa.; Cumberland and Tonoloway, Md.; Ridgeville, W. Va.; Bells Valley and Little Moccasin Gap, Va.

\section{Genus BYTHOCYPRIS Brady.}

\section{Bythocypris Favulosa Jones.}

Plate IX, figures 13-15.

1889. Bythocypris favulosa. Jones, Am. Geologist, vol. 4, 1889, p. 338, pl. opp. p. 342, figs. 1 and $2 \mathrm{a}, \mathrm{b}, \mathrm{c}$.

Jones's original description follows:

These small specimens are only casts, and are doubtfully referred to Bythocypris, as the genus most convenient to receive them according to their subovate-oblong shape. ${ }^{1}$ The hollow cast and another similar but imperfect cast show a coarsely reticulate or honeycomb-like structure, which holds the place of the external surface of the valve. This is not an unusual ornament of some ostracodous valves; but it is here very coarse in proportion to the area of the valve, and it is unusual in such simple cypridiform species as the Bythocypris, etc. One specimen is about 1 millimeter, and the other a little more in length. From buff-colored noncalcareous shale of the Marcellus limestone, ${ }^{2}$ Perry County, Pa., near New Bloomfield.

The figures represent specimens from the same locality which supplied the types of the species. The peculiar honeycomb-like surface markings of this species serve to distinguish it from any other ostracode in the fauna.

Distribution.-This is a common and widely distributed form. It is represented in the collections from the following localities: New Bloomfield and Blair County; Pa.; Bells Valley, Clifton Forge, Little Moccasin Gap, and Mendota, Va.

1 For some other Paleozoic ostracodes referable to this genus, see Annals and Mag. Nat. Hist., 5th ser., vol. 18,1886 , p. 250 , etc.; vol. 19,1887 , p. 184 , etc.

2 In the Hamilton group of the Upper Helderberg (Middle Devonian of the United States). 
Genus ULRICHIA Jones.

\section{UlRichia CONRADI Jones.}

Plate IX, figure 12.

1.890. Ulrichia conradi. Jones, Quart. Jour. Geol. Soc. London, vol. 46, 1890, p. 544, fig. 2.

Jones's original description follows:

Length, 0.8 millimeter; height, 0.46 millimeter. A small left valve, suboblong, straight on the back, obliquely curved below, rounded at the ends, the posterior higher and fuller than the anterior. Two largish prominent knobs, oval in section and obliquely peaked (much too neatly oval in the figure), divide the dorsal region in three nearly equal portions; the front tubercle is smaller than the other. The surface of the valve is faintly reticulated, and has along the free borders a neat marginal ridge.

This species is represented in the collections by a mold of a single individual, which shows the two dorsolateral knobs of unequal size and the reticulated surface characterizing the species.

Distribution.-McVeytown, Pa.

\section{Genus OCTONARIA Jones.}

\section{Octonaria stigmata Ulrich.}

Plate IX, figure 11.

1891. Octonaria stigmata. Ulrich, Jour. Cincinnati Soc. Nat. Hist., vol. 13, 1891, p. 193, pl. 16, figs. 8 a, b.

Ulrich's original description follows:

It is very difficult to distinguish the back from the ventral edge, and the anterior from the posterior end in species of this peculiar genus. Species variable, valves with a raised and longitudinally ridged area occupying most of the surface. Ridges more or less irregularly thickened at intervals, or united by a greater or less number of crossbars, producing a coarse network. The typical form is ovoid or subrhomboidal in shape, with the anterior extremity the narrowest; posterior end strongly curved in the lower half, sloping forward in the upper half; ventral edge gently convex, curving neatly up into the anterior curve which is the most prominent above the middle; back straight, without cardinal angles. Counting the marginal ridge of the elevated area, there are five longitudinal ridges in the anterior half. In the posterior half they become irregular. Size: Length, 0.88 millimeter; height, 0.53 millimeter.

Distribution.-Comparatively rare, having been found in only one locality 2 miles west of Canoe Creek, Blair County, $\mathrm{Pa}$.

Genus LEPERDITIA Rouault.

LEPERDITIA? cf. SUBROTUNDA Ulrich.

Plate IX, figure 7.

1891. Leperditia ? subrotunda. Ulrich, Jour. Cincinnati. Soc. Nat. Hist., vol. 13, 1891, p. 181, pl. 16, figs. $1 \mathrm{a}, \mathrm{b}$; c.

Ulrich's original description follows:

Size of left valve: Length, 0.68 millimeter; thickness, 0.21 millimeter. Carapace emall, short, rounded, uniformly convex, encircled, except at the strongly convex 
ventral edge, by a flattened border, widest in the posterodorsal region. Dorsal edge scarcely straight, gently curving into the ends. Ventral overlap distinct. Surface smooth and even, without eye tubercle or muscle spot. The development of a flange at the dorsal border is a very unusual feature in this genus. $L$. sinuata Hall has nearly the same shape, but is without a flange, and so far as known its valves do not overlap at the ventral margin. I am-inclined to believe that species of this character cught to be arranged with Aparchites rather than Leperditia. Position and locality: Devonian Bryozoa bed, Falls of the Ohio. Rare.

A circular or subcircular ostracode occurs sparingly as casts of the shell at three or four localities represented by the collections. These agree with Ulrich's figures of $L$. subrotunda, except that the projecting flattened border feature appears to be developed but slightly or not at all; the form here compared with $L$. subrotunda may represent a closely related species.

Distribution.-Hollidaysburg and Upper Reese, Blair County, Pa.; Berkeley Springs, W. Va.; and Little Moccasin Gap, Va. 
PLATE II.

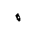




\section{PLATE II. \\ ZAPHRENTIS cf. SIMPLEX (p. 66).}

Figure 1. Lateral view. New Bloomfield, Pa.

Cystiphyllum americanum (p. 67).

Fiqure 2. Lateral view of specimen with exfoliated epitheca. Big Stone Gap, Va.

Pleurodictrum sp. undet. (p. 66).

Figure 3. Natural cast, showing filling of intramural pores between the cells. Clifton Forge, Va.

\section{BLOTHEROPHYLLUM DECORTICATUM (p. 67).}

Figure 4. Lateral view of specimen with eroded epitheca. Big Stone Gap, Va.

Polygnathus sp. undet. (p. 67).

Figure 5. Incomplete jaw. The tips of four or five teeth which were discernible on the specimen are not brought out in the illustration. Tonoloway, Md.

Lingula cf. Ligea (p. 69):

Fraure 6. Pedicle (?) valve. Blair County, Pa.

Pholidops cf. areolata (p. 70).

Figure 7. Natural mold of the exterior of the pedicle valve.

8. Natural cast of the interior of the pedicle valve. The slender impressed median line of the figure has about twice the proper length. It is conspicuous only near the apex of the crescent-shaped depression, $\times 5$. Bells Valley, Va.

Orbiculoidea lodiensis var. media (p. 69).

FIquine 9. Exterior of a partly exfoliated brachial valve. Bells Gap, Va.

10. Interior of a partly exfoliated pedicle valve. The more exfoliated portions are smooth, not striated, as indicated by figure. Bells Gap, Va.

11. Natural cast of the exterior of pedicle valve, showing concentric striæ. East of Cumberland, Md.

\section{Leptostrophia perplana (p. 75).}

Figure 12. Natural cast of interior of pedicle valve. New Bloomfield, Pa.

13. Exterior of pedicle valve of a small specimen. Schuylkill Haven, Pa. 118 


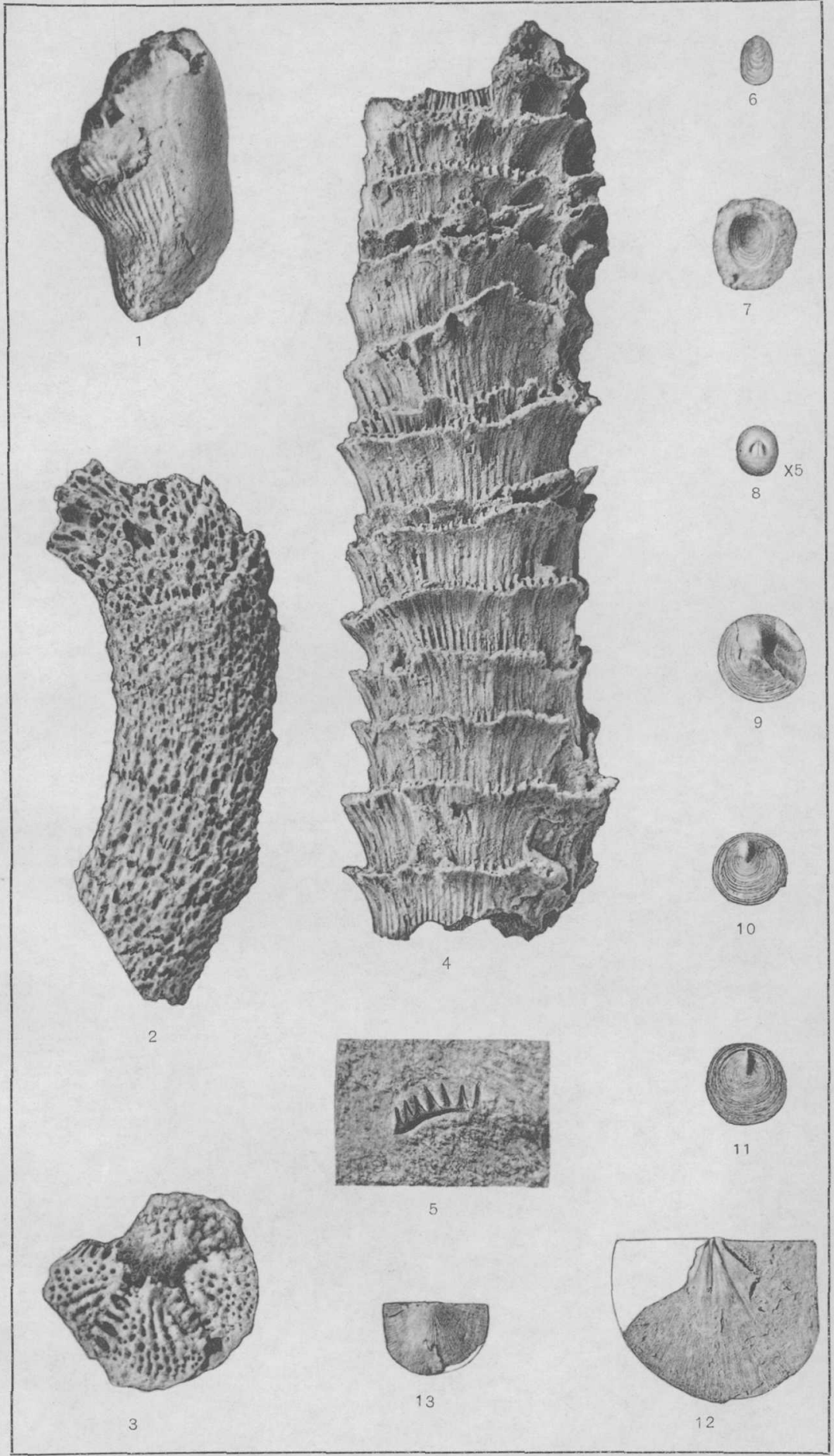

ONONDAGA FAUNA 
PLATE III. 


\section{PLATE III.}

\section{Leptostrophia Perplana (p. 75).}

Figure 1. Enlargement of part of the surface of a brachial valve, showing fine concentric striæ, $\times 4$. Schuylkill Haven, $\mathrm{Pa}$.

Stropheodonta INequistriata (p. 76).

FIGURE 2. Natural cast of interior of a fragmentary pedicle valve, which has been slightly compressed laterally, $\times 3$.

3. Partly exfoliated pedicle valve. Blair County, $\mathrm{Pa}$.

4. Gutta-percha cast of the exterior, $\times 3$.

Figures 2 and 4 illustrate the interior and exterior of the same individual. New Bloomfield, Pa.

\section{Stropheodonta patersoni (p. 75).}

Figure 5. Fragment of a pedicle valve, $\times 2$. Mendota, Va.

6. Fragmentary brachial valve, $\times 3$. Little Moccasin Gap,. Va.

Schuchertella pandora (p. 76).

Figure 7. Pedicle valve of a small shell. Little Moccasin Gap, Va.

8. Brachial valve. Mendota, Va.

\section{Chonetes arcuatus (p. 73).}

Figure 9. Exterior of a partly exfoliated pedicle valve.

Figures 10, 11. Natural cast of the interior of a pedicle valve, showing hinge teeth, area, etc. Little Moccasin Gap, Va.

FIgURe 12. Natural mold of the exterior of part of a brachial valve.

\section{Chonetes mucronatus (p. 71).}

Figure 13. Small pedicle valve, $\times 3$. Cumberland, Md.

14. A pedicle valve of average size and appearance, showing the long spines, $\times 2$. Cumberland, $M d$.

\section{Chonetes Hemisphericus (p. 70).}

Figure 15. Pedicle valve, $\times 2$.

16. Lateral profile of same specimen, $\times 2$. Schuylkill Haven, $\mathrm{Pa}$.

\section{ChONETES cf. SETIGERUS (p. 71).}

Figure 17. Pedicle valve, $\times 2$. Selinsgrove Junction, Pa. 


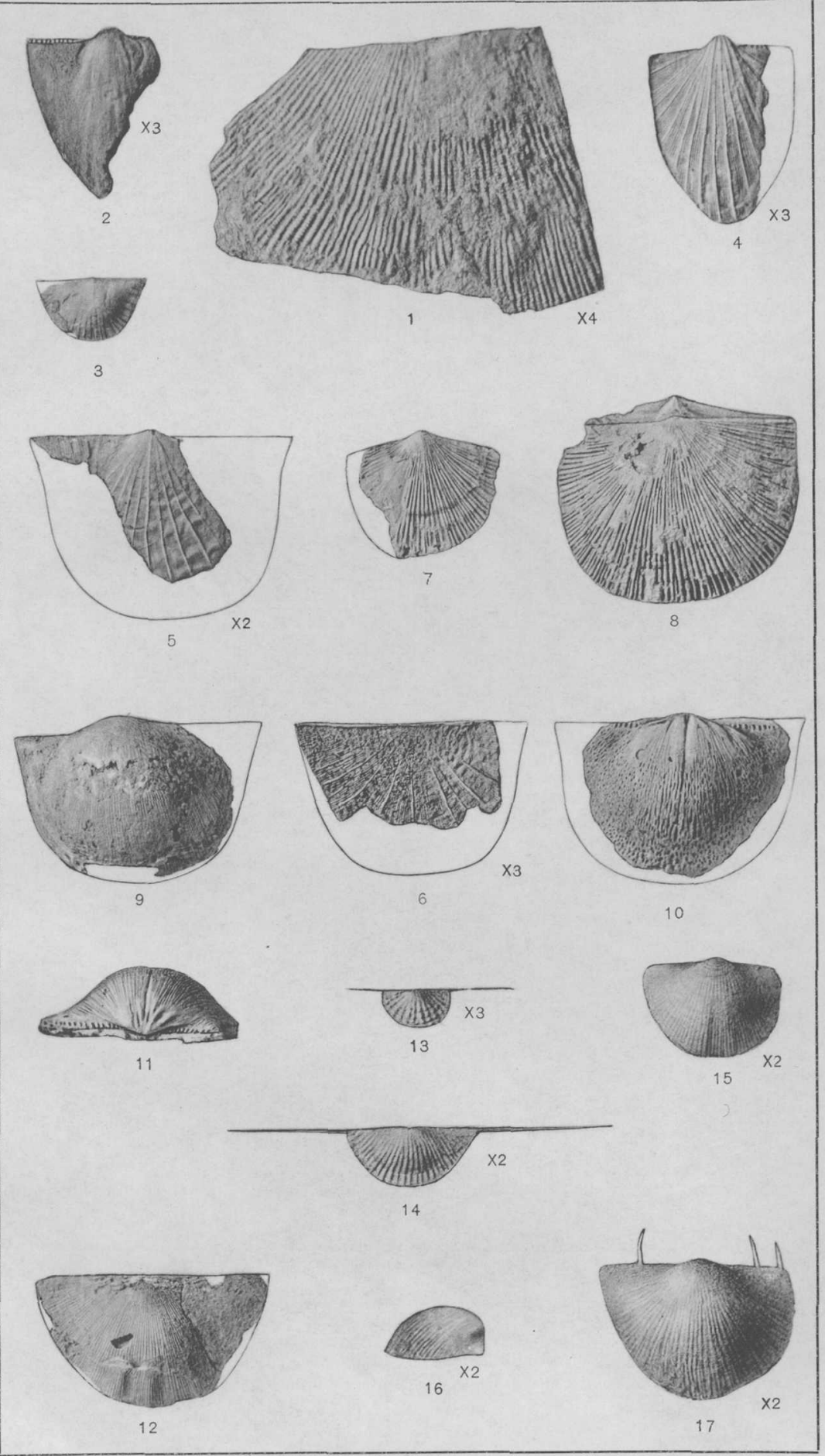

ONONDAGA FAUNA 
PLATE IV.

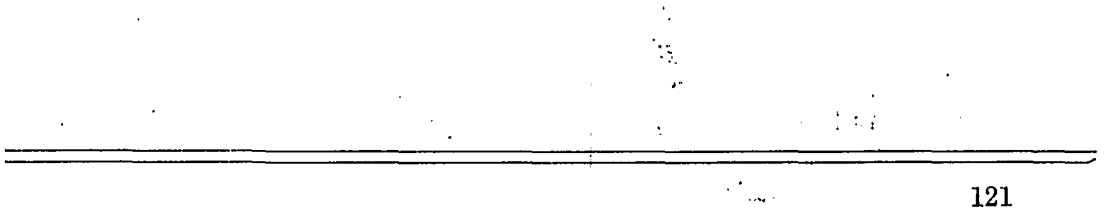




\section{PLATE IV.}

Chonetes Buttsi n. sp. (p. 72).

Frgure 1. Brachial valve, $\times 2$. Blair County, $\mathrm{Pa}$.

2. Surface of a brachial valve, $\times 2$. Blair County, $\mathrm{Pa}$.

3. Pathologic pedicle valve in which the left side of the hinge line has failed to develop normally, but which shows the normal number of spines, $\times 2$. Blair County, $\mathrm{Pa}$.

4. Pedicle valve of type specimen, $\times 2$. A natural mold of Bollia ungula forms a small depression in the surface of the shell. Blair County, $\mathrm{Pa}$.

Chonetes rugosus n. sp. (p. 72).

Fraure 5. Exfoliated pedicle valve, showing imperfectly the subtended processes of the mucronate spines, $\times 2$. Three miles east of Cumberland, Md.

6. Type, showing a pedicle valve with the peculiar spines attached laterally to the hinge line, $\times 2$. Three miles east of Cumberland, Md.

7. Natural mold of the exterior of a pedicle valve, $\times 2$. Three miles east of Cumberland, Md.

LEPT aENISCA aUstralis n. sp. (p. 78).

Fraure 8. Natural mold of exterior of a pedicle valve, showing imperfectly fine radiating striæ and rugose concentric striæ, $\times 2$. Berkeley Springs, W. Va.

9, 10. Two natural casts of pedicle valves. Berkeley Springs, W. Va.

11. Type specimen, showing natural mold of a pedicle valve, $X 2$. Berkeley Springs, W. Va.

12. Natural mold of the interior of a brachial valve. New Bloomfield, $\mathrm{Pa}$. 


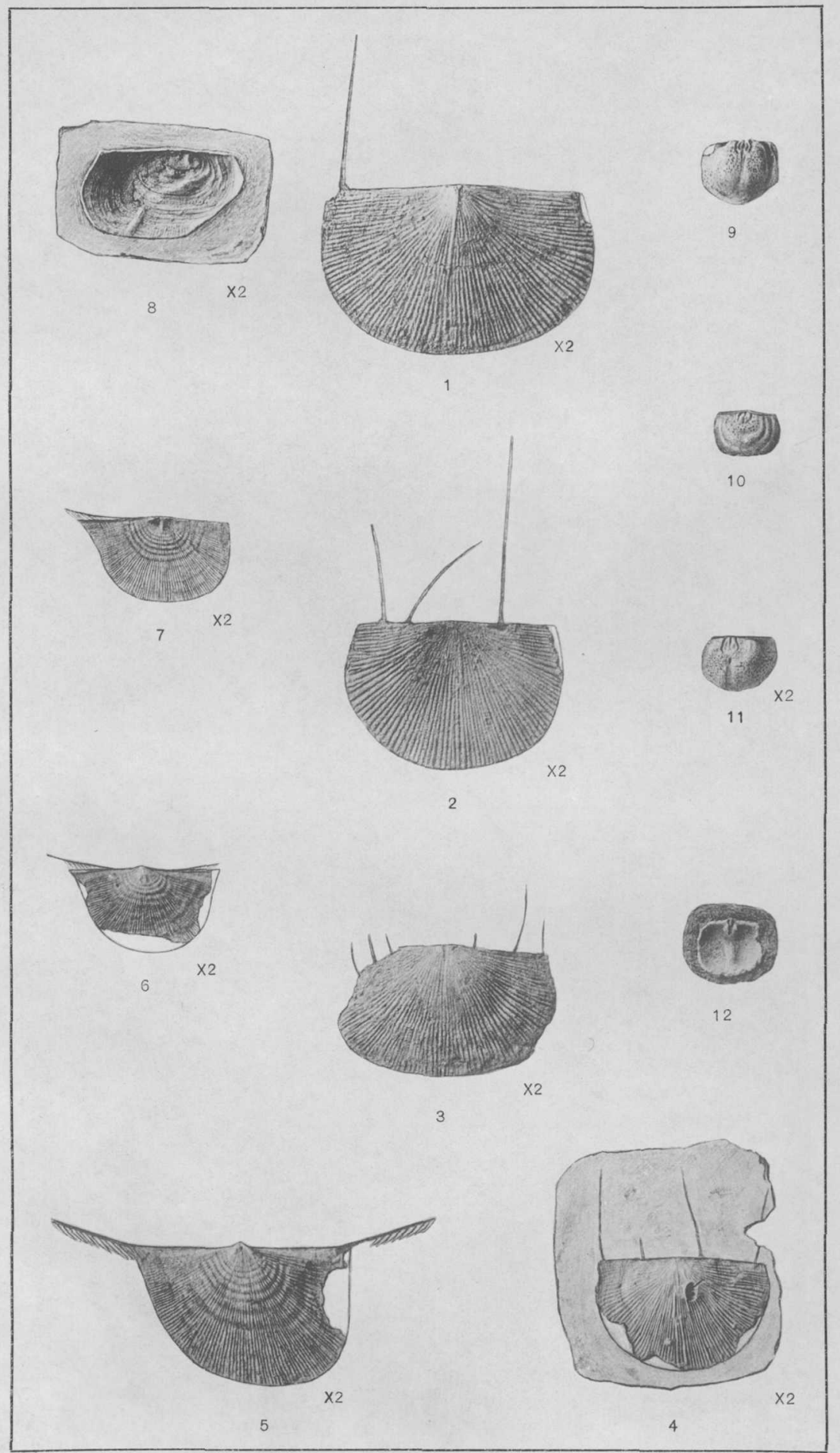

ONONDAGA FAUNA 
PLATE V. 


\section{PLATE V.}

Pholidostrophia pennsyldanica n. sp. (p. 74).

Frgure 1. Type specimen; pedicle valve, $\times 3$. East of Cumberland, Md.

2. Natural cast of the interior of a pedicle valve, showing short and very slender median septum. Berkeley Springs, W. Va.

Productella navicella (p. 78).

Figure 3. Anterior of a pedicle valve. Schuylkill Haven, $\mathrm{Pa}$.

Cyrtina hamiltonensis (p. 81).

Figure 4. Brachfal view of a natural cast. New Bloomfield, Pa.

Strophalosia truncata (p. 77).

Figure 5. Natural cast of the interior of a brachial valve, showing crenulated hinge line and very slender septum, $\times 2$. Ridgeville, $W$. Va.

6. Pedicle valve, showing truncated umbone, $\times 2$.

7. Exterior of brachial valve, showing crenulated margin at hinge line, $\times 2$. Ridgeville, W. Va.

\section{ANoplia nucleata (p. 73).}

Figures 8,11 . Views of natural molds of two pedicle valves, showing two types of median septum, one terminating anteriorly in an indistinct $Y$-shaped process, $\times 3$. Mendota, Va.

Fraure 9. Cardinal view of natural cast of pedicle valve, showing filling of oblique cardinal tubes, $\times 5$. Mendota, Va.

10. Pedicle view. Mendota, Va.

\section{Dalmanella lenticularis (p. 79).}

Fraure 12. Brachial view, $\times 2$.

13, 16. Natural molds of the interior of two brachial valves.

14, 15. Two fragmentary natural molds of pedicle valves.

All the specimens are from Berkeley Springs, W. Va.

Rhipidomella vaNuXemi (p. 79).

Figures 17, 18. Two natural casts of brachial valves. New Bloomfield, Pa.

19. Exfoliated pedicle valve. Mendota, Va.

Ambocelia ef. nana (p. 83).

Figure 20. Pedicle valve, $\times 2$. McVeytown, $\mathrm{Pa}$.

21-23. Pedicle, brachial, and lateral views of another specimen, $X 2$. McVeytown, $\mathrm{Pa}$.

Atrypa Reticularis (p. 80).

Frgures 24, 25. Brachial and anterior profiles of exfoliated shell. New Bloomfield, Pa. 


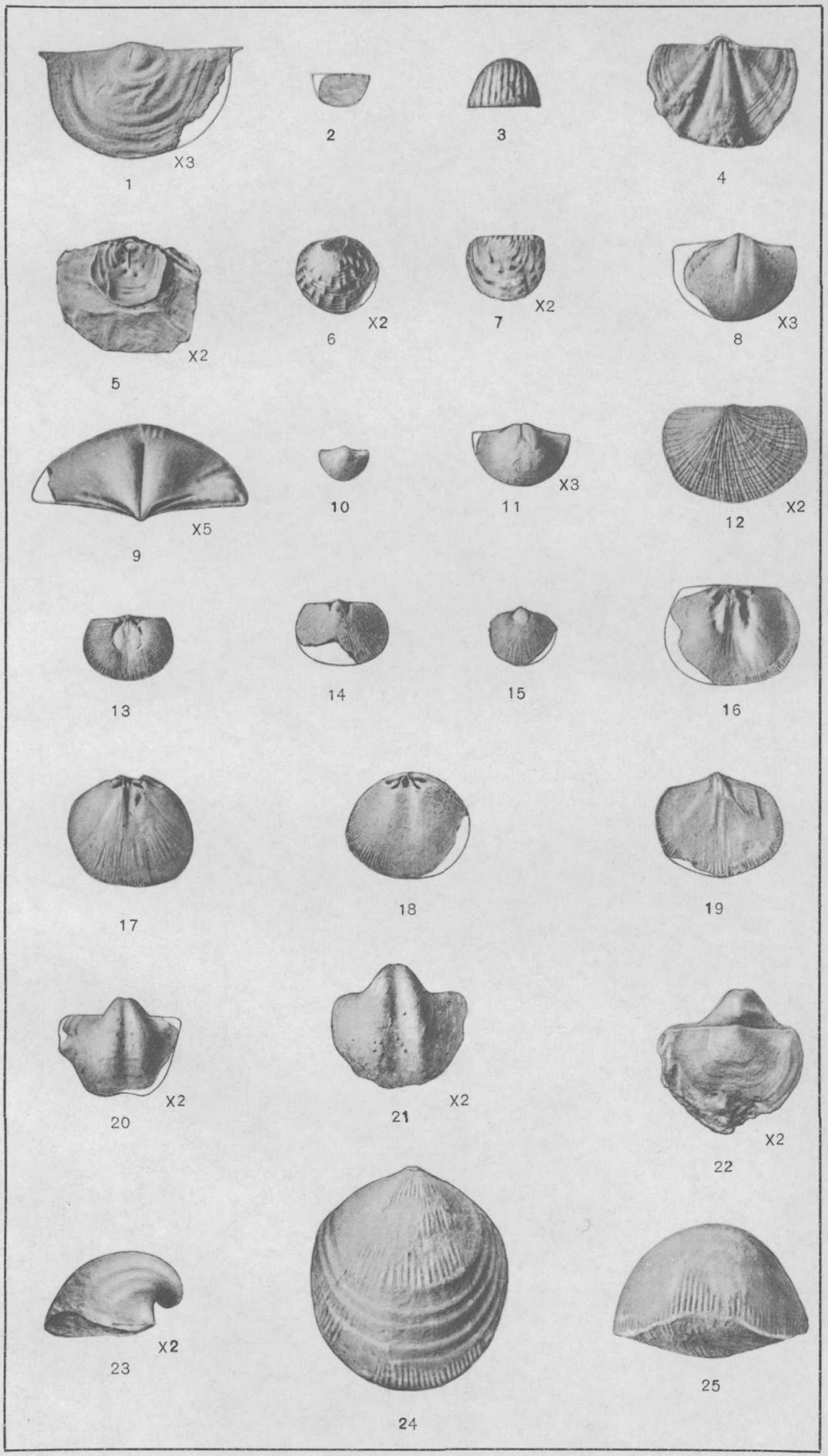

ONONDAGA FAUNA 
PLATE VI. 


\section{PLATE VI.}

\section{Anoplotheca acutiplicata (p. 84).}

Frgures 1-3. Brachial, anterior, and pedicle views of one of the types. Photographic reproductions of the specimen illustrated by Hall, Nat. Hist. Paleontology, vol. 4, pl. 57, figs. 34-37.

4-6. Brachial, anterior, and pedicle views of an exfoliated shell. Blair County, $\mathrm{Pa}$.

7-9. Three specimens showing variation in anterior profile. These are exfoliated specimens, hence do not show the characteristic rugose concentric striæ. Blair County, $\mathrm{Pa}$.

10, 11. Brachial and pedicle views of a slightly distorted and partly exfoliated shell having concentric striæ. New Bloomfield, $\mathrm{Pa}$.

12. Brachial view of another individual. Clifton Forge, Va.

13. Interior of brachial valve from an artificial cast: Ridgeville, W. Va.

14. Natural cast of the interior of a brachial valve. Three miles east of Cumberland, Md.

15. Natural mold of the interior of a brachial valve, $\times 2$. East of Cumberland, $\mathrm{Md}$.

\section{SPIRIFER VARICOSUS (p. 82),}

Figure 16. Fragmentary brachial valve. Mendota, Va.

\section{SPIRIFER ACUMINatus (p. 81).}

Figures 17, 18. Anterior and lateral profiles of a partly exfoliated shell. The figures fail to show the fine transverse strix in the sinus and the bifurcating plications exhibited by the specimen. Schuylkill Haven, $\mathrm{Pa}$. 


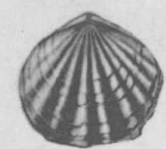

1
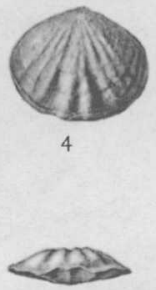

7

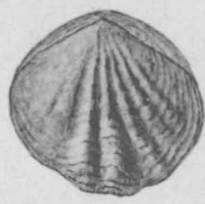

10

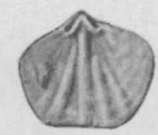

13
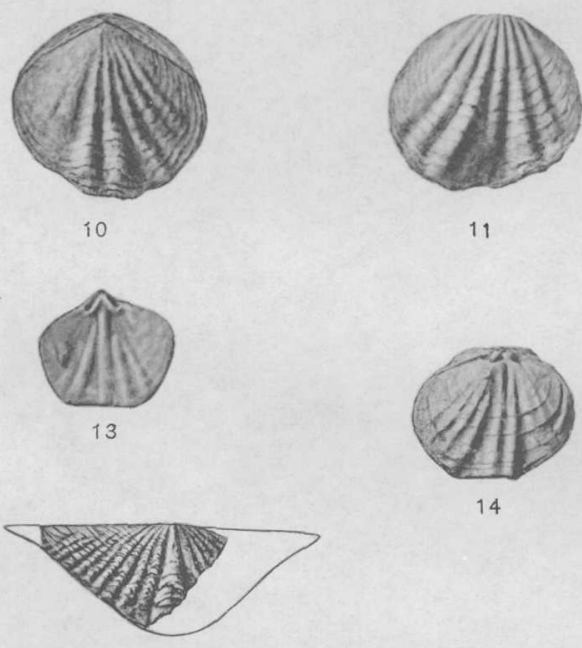

11

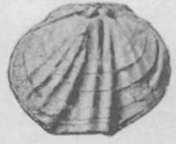

14

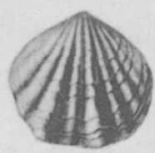

3

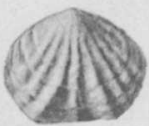

6

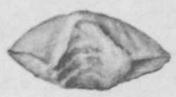

9

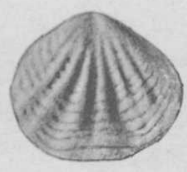

12

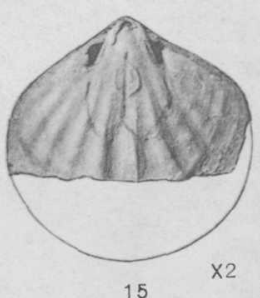




\section{PLATE VII.}




\section{PLATE VII. \\ Crantena cf. romingeri (p. 86).}

Figures 1, 2. Two individuals showing interior aspect of brachial and pedicle valves, $\times 2$. Ridgeville, W. Va.

Nucleospira concinina (p. 86).

Figure 3. Pedicle view, $\times 3$. Mendota, Va.

4, 5. Natural casts of the interior of pedicle valves. Mendota, Va.

Reticularia cf. modesta (p. 82).

- Fiqure 6. Brachial valve, $\times 2$. Mendota, Va.

Meristella nasuta (p. 85).

Fraure 7. Exfoliated pedicle valve showing muscular impression. Mendota, Va.

Pterochenia fragilis (p. 90).

Figure 8. Fragmentary right valve, $\times 2$. Poplar Hill, Va.

9. Left valve, $\times 2$. Poplar Hill, Va.

Paleoneilo cf. constricta (p. 87).

Figure 10. Left valve. New Bloomfield, Pa.

Cypricardinia indenta (p. 94).

Fraure 11. Fragmentary right valve, $\times 3$. Little Moccasin Gap, Va.

12. Fragment of natural mold of a valve, showing surface marking, $\times 5$. Mendota, Va.

Nuculites modulatus n. sp. (p. 89).

Figure 13. Type specimen. Ridgeville, W. Va.

.14. Another individual. Ridgeville, W. Va.

NucUla cf. CORBULIFormis (p. 88).

Figure 15. Fragmentary right valve, $\times 2$. Berkeley Springs, W. Va.

LUNULICARDIUM CURTUM (p. 89).

Figure 16. Right valve. Ridgeville, W. Va.

Panenka cf. Dichotoma (p. 96).

Figure 17. Fragmentary right valve. Ridgeville, W. Va. 

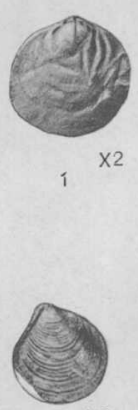

9

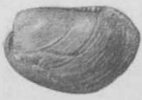

10

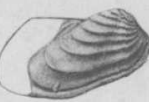

$\times 3$

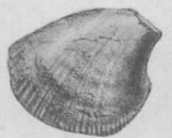

16

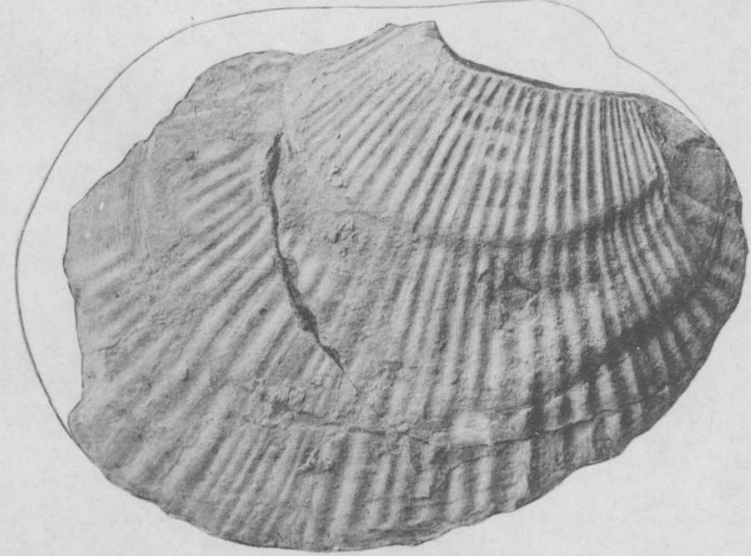

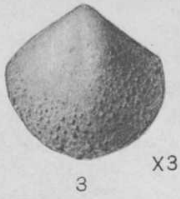
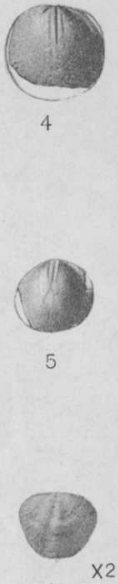

6
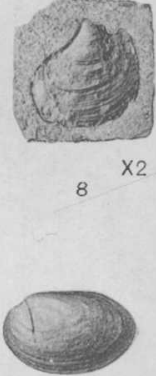

13

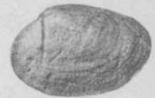

14

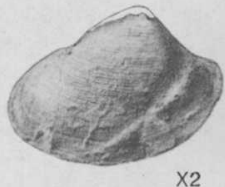

15 


\section{PLATE VIII.}

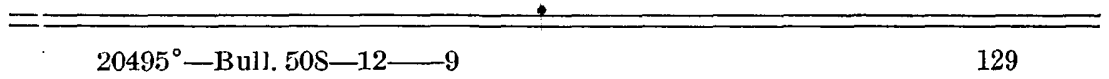




\section{PLATE VIII.}

\section{Modiomorpha subalata (p. 93).}

Figure 1. An imperfect right valve.

Aviculopecten equilatera (p. 93).

Frgures 2 to 3 . Two left valves showing variation in erectness of the shell, $\times 2$. Blair County, Pa., and Ridgeville, W. Va.

Pterinea sp. undet. (p. 91).

Figure 4. Left valve showing surface ornamentation. Little Moccasin Gap, Va.

$$
\text { Leiopteria Latis (p. 95). }
$$

Figure 5. Left valve, $\times 2$. 3 miles east of Cumberland, Md.

ACtinopteria muRicata (p. 92).

FiaUre 6. Left valve showing radiating and concentric striæ.

Pleurotomaria crassa n. sp. (p. 102).

Fraures 7, 8. Type specimen showing ornamentation on opposite sides, $\times 2$. Blair County, $\mathrm{Pa}$.

$$
\text { Loxonema hamiltonia (p. 100). }
$$

Figure 9. Flattened specimen showing transverse striæ. Ridgeville, W. Va.

10. Small specimen of the same species. New Bloomfield, Pa.

$$
\text { Naticopsis sp. undet. (p. 98). }
$$

Fiqure 11. Lateral view, $\times 4$. Ridgeville, W. Va.

$$
\text { Platyostoma turbinata (p. 97). }
$$

Figure 12. Exfoliated shell. The figure fails to show the revolving band and transverse striæ, traces of which are preserved by the specimen. McVeytown, Pa.

$$
\text { Platyceras thetis (p. 99). }
$$

Figure 13. Compressed specimen, in which the anterior margin of the shell is broken away.

BELLEROPHON LEDA (p. 101).

Figure 14. View showing revolving and fine transverse lines, $\times 3$. Schuylkill Haven, $\mathrm{Pa}$. 


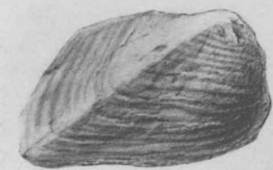

1

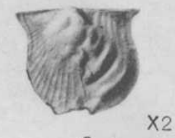

2

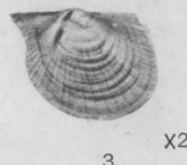

3
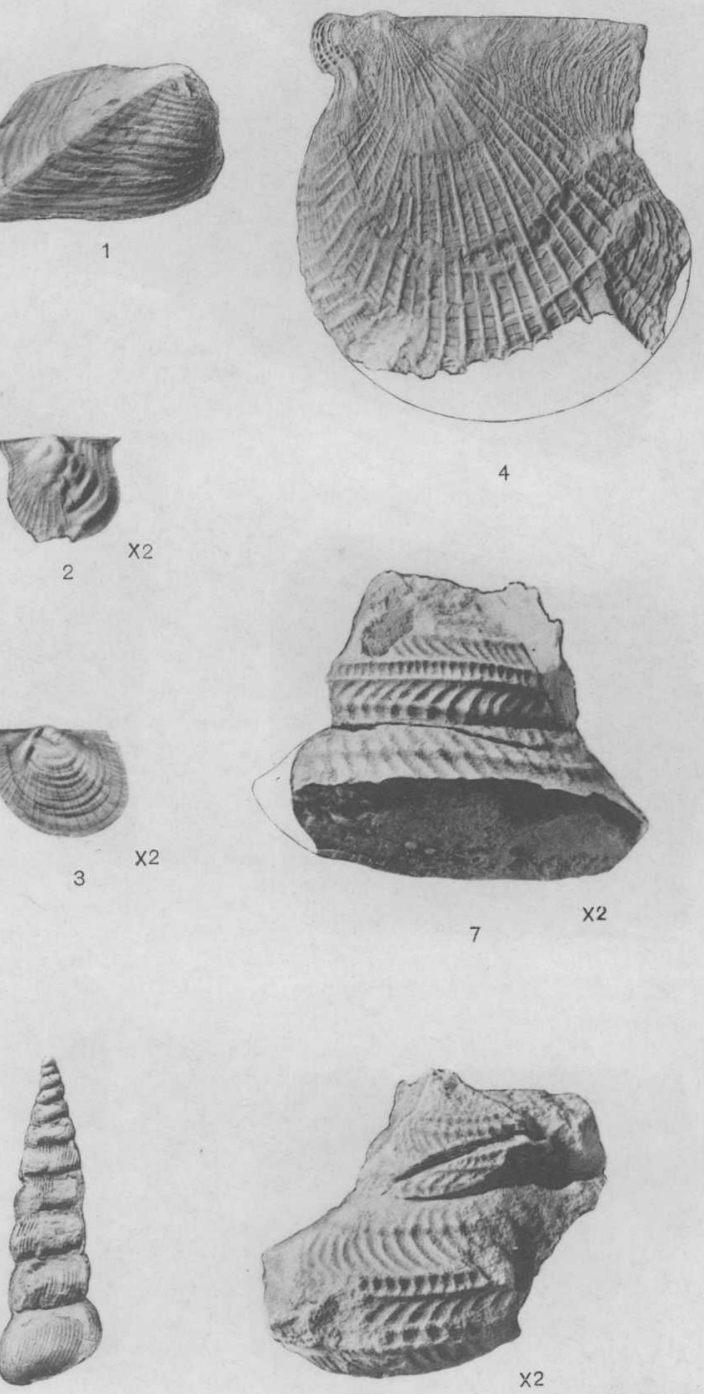

9

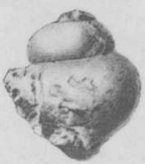

12
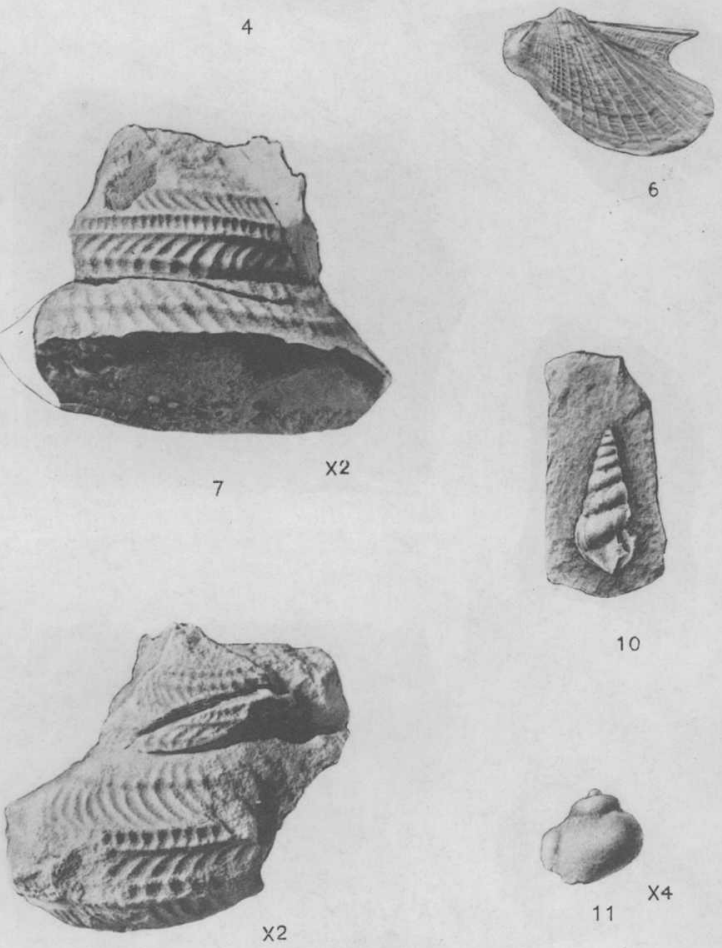

10

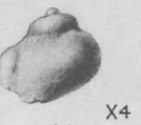

8
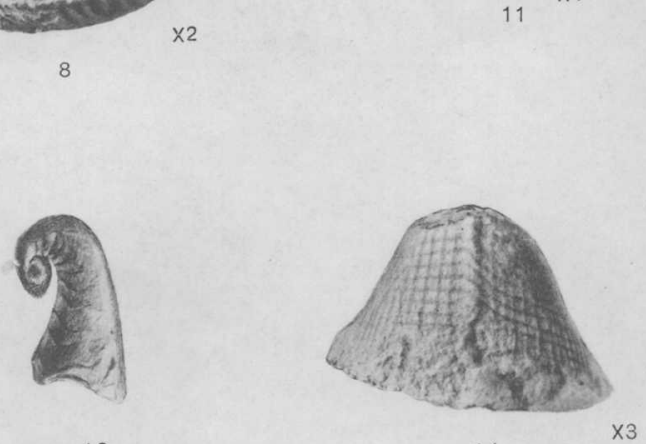

13

14 
PLATE IX. 


\section{PLATE IX.}

Coleolus? CuRvatus n. sp. (p. 105).

Figure 1. Type specimen. New Bloomfield, Pa.

2. Another individual, $\times 2$. Blair County, $\mathrm{Pa}$.

BaCtrites aCiculum (p. 104).

Figure 3. Fragmentary tube. Sassin, Va:

Tentaculites gracmistriatus (p. 103).

Figure 4. External impression of a specimen in shale, $\times 5$. Bells Valley, Va.

Tentaculttes scalariformis (p. 103).

Figure 5. Fragmentary specimen, $\times 4$. Mendota, Va.

\section{Agoniatites expansus (p. 107).}

Figure 6. Outline figure showing character of surface striæ. Cumberland, Md.

LEPERDITIA? cf. SUBROTUNDA (p. 115).

Figure 7. Right (?) valve, $\times 20$. Little Moccasin Gap, Va.

Bollia obesa (p. 114).

Figure 8. Natural cast of a left valve, $\times 20$. New Bloomfield, Pa.

Bollia ungula (p. 113).

Figure 9. Natural cast of a left valve, $\times 20$. Rees Tannery, Mineral County, W. Va. 10. Dorsal view of a slightly distorted specimen, $\times 20$. Ridgeville, W. Va.

Octonaria stigmata (p. 115).

Figure 11. Right valve, $\times 20$. New Bloomfield, Pa.

\section{ULRICHIA CONRADI (p. 115).}

Figure 12. Natural mold of the exterior of a left valve, $\times 20$. McVeytown, Pa.

\section{BYTHOCYPRIS. FAVULOSA (p. 114).}

FIGURE 13. Natural mold of the exterior of one of the valves, $\times 20$. New Bloomfield, Pa.

14. Natural mold of exterior of another individual. New Bloomfield, $\mathrm{Pa}$.

15. Natural cast of the interior of a left valve, $\times 20$. New Bloomfield, $\mathrm{Pa}$. 


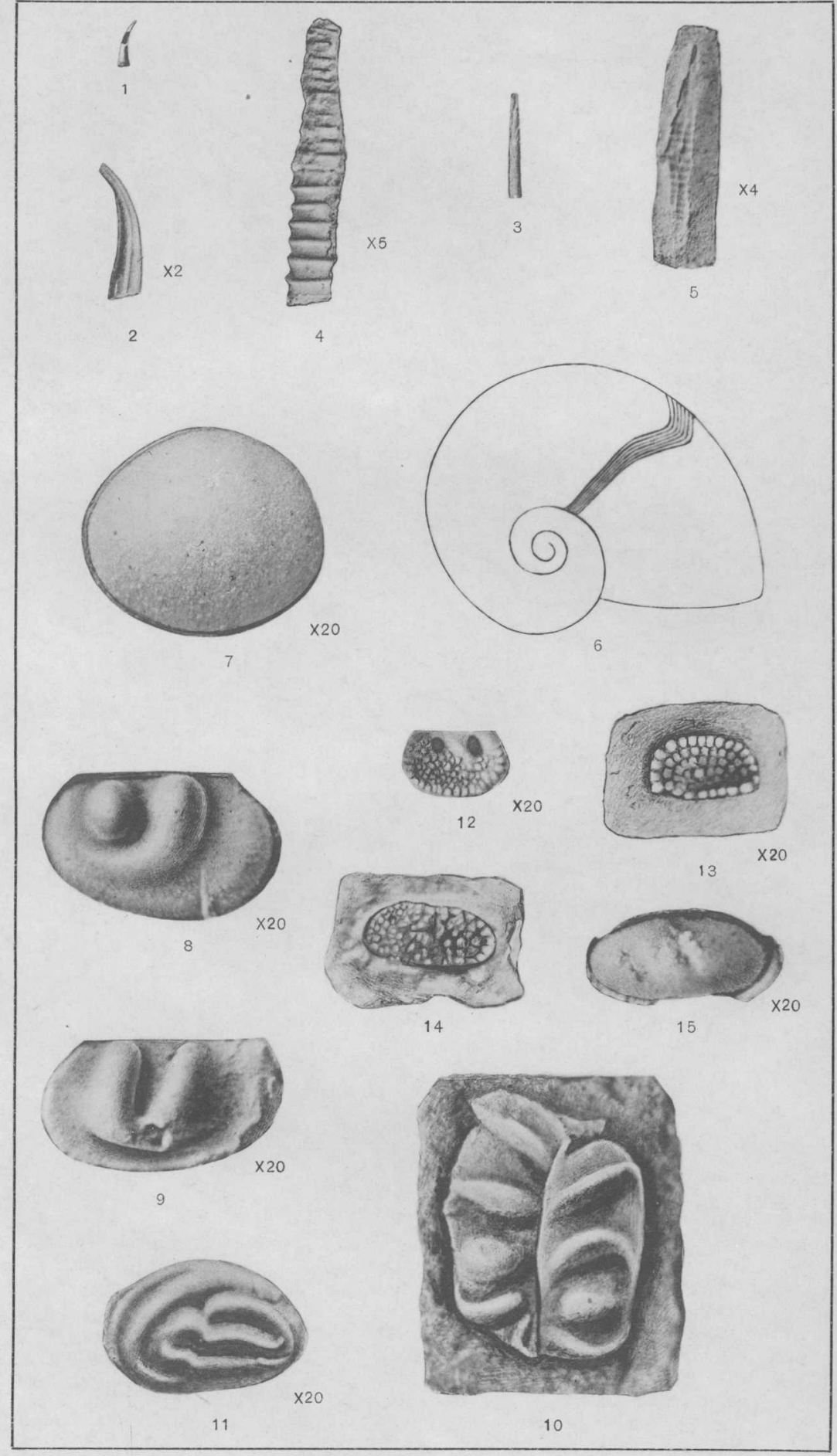

ONONDAGA FAUNA 


\section{PLATE X.}




\section{PLATE X. \\ Phacops Rana (p. 107).}

Frgure 1. Internal cast of a cephalon. Bells Valley, Va.

2. Natural cast of a pygidium and a part of a thorax. Bells Valley, Va.

3. View of a small cephalon. Blair County, $\mathrm{Pa}$.

4. View of another specimen. Blair County, $\mathrm{Pa}$.

5. Natural cast of a fragmentary specimen, showing thorax, pygidium, and part of cephalon. New Bloomfield, Pa.

\section{Phacops cristata (p. 107).}

Fraure 6. Cephalon and part of the thorax of an enrolled specimen, showing axial and genal spines. Alinda, $\mathrm{Pa}$.

7. Lateral view of an enrolled specimen with a partly crushed glabella, showing genal spine base. Alinda, Pa.

8. Fragmentary thorax and pygidium, showing axial spines. Ridgeville, W. Va.

Phacops cristata var. Pipa (p. 108).

Frgure 9. Fragmentary enrolled thorax referred to this species. Alinda, Pa.

10. Pygidium, showing duplicate character of pleural annulations. New Bloomfield, Pa.

Odontocephalus Rgeria (p. 109).

Frgure 11. Natural cast of a fragmentary specimen. The anterior and right marging of the cephalon have been broken away, and the left cheek has been laterally compressed. Alinda, Pa.

Dalmanites (Coronura) aspectans (p. 109).

Figure 12. Left cheek.

13. Part of a detached eye on same slab and closely adjacent to the preceding specimen, to which it probably belonged. Blair County, $\mathrm{Pa}$.

Cryphaus cf. Boothi var. Calliteles (p. 108).

FIGURE 14. Cast of the interior of a fragmentary cephalon. Ridgeville, W. Va.

15. Another fragmentary cephalon, $\times 2$. Blair County, Pa. 


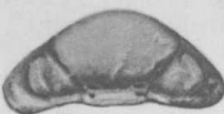

1

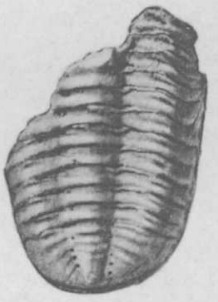

2

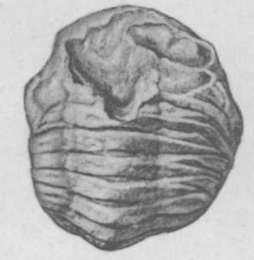

9
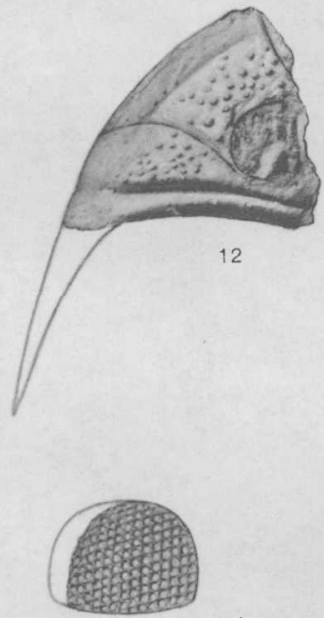

13

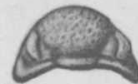

3

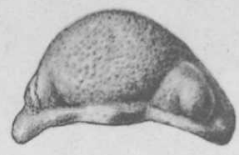

4

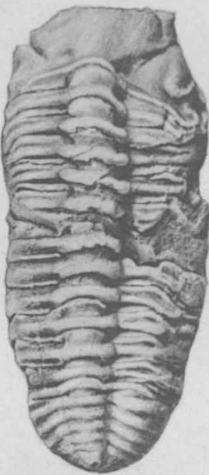

5

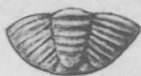

10

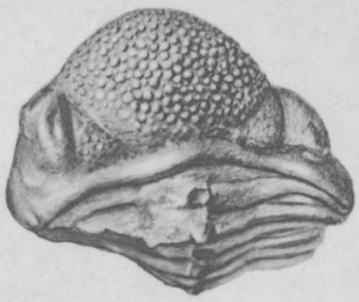

6

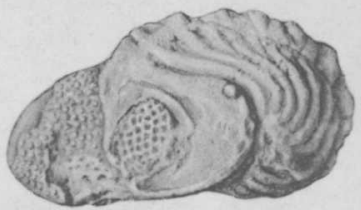

7

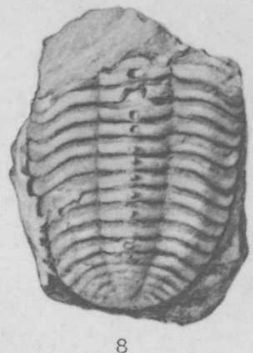

8

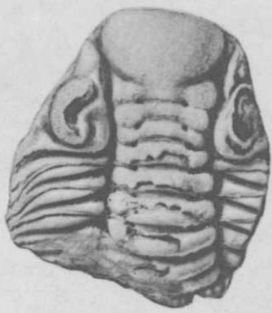

11

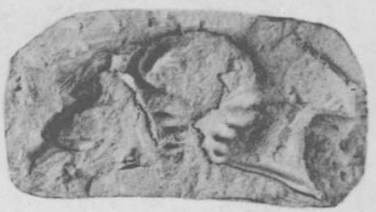

15 


\section{PLATE XI.}




\section{PLATE XI.}

Cryphates ef. Boothi var. calliteles (p. 108).

Figure 1. Natural cast of a fragmentary cephalon and thorax. The impression of the spine of the left cheek, which is not seen in the figure, extends on the specimen to the third annulation or beyond. The pygidium near the posterior end of thorax probably belongs to another species. New Bloomfield, Pa.

Dalmanites sp. undet. (p. 112).

Figure 2. Fragmentary natural mold of a cephalon showing crenulated anterior border in the median portion, $\times 2$. Rees. Tannery, Keyser County, W. Va.

\section{ODONTOCEPHALUS AGERIA (p. 109).}

FIgURE 3. Natural cast of the interior of a fragmentary individual, showing the lanceolate processes at the ends of the pleura below the spine. Alinda, $\mathrm{Pa}$.

4,5. Posterior portions of two individuals with distorted pygidia, showng the posteriorly directed processes at the outer extremities of the pleuræ. These specimens represent in the main casts of the interior. Alinda, $\mathrm{Pa}$. 


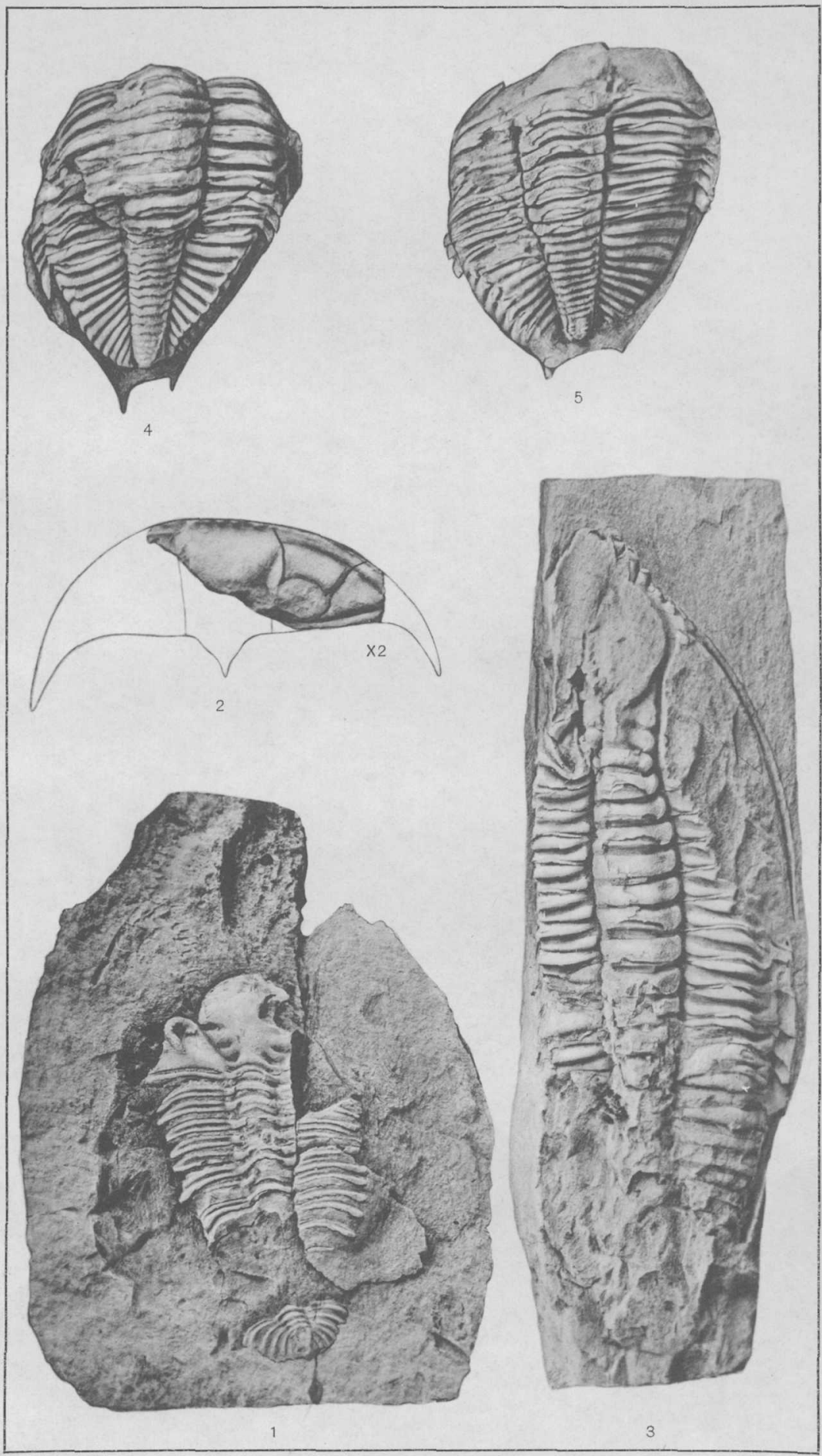


PLATE XII. 


\section{PLATE XII.}

ODONTOCEPHALUS TEGERIA (p. 109).

Figure 1. A partly exfoliated individual, distorted and somewhat shortened by pressure. Alinda, $\mathrm{Pa}$.

2,3 . Two views of an individual having the tail doubled under the thorax. With the exception of the anterior.portion of the pygidium the specimen is mainly a cast of the interior. New Bloomfield, Pa.

4-5. Two specimens of the denticulated frontal doublure, showing some of the variations in its outline. Figure 4 shows the second from the left of the toothlike processes imperfectly developed. The localities represented are: No. 4, McVeytown; No. 5, Blair County.

7, 8. Large individuals in which the test is but slightly exfoliated. Alinda, Pa.

Odontocephalus Selenurus (p. 109).

Figure 6. View of portion of denticulated frontal doublure. Falling Spring, Perry County, Pa. 


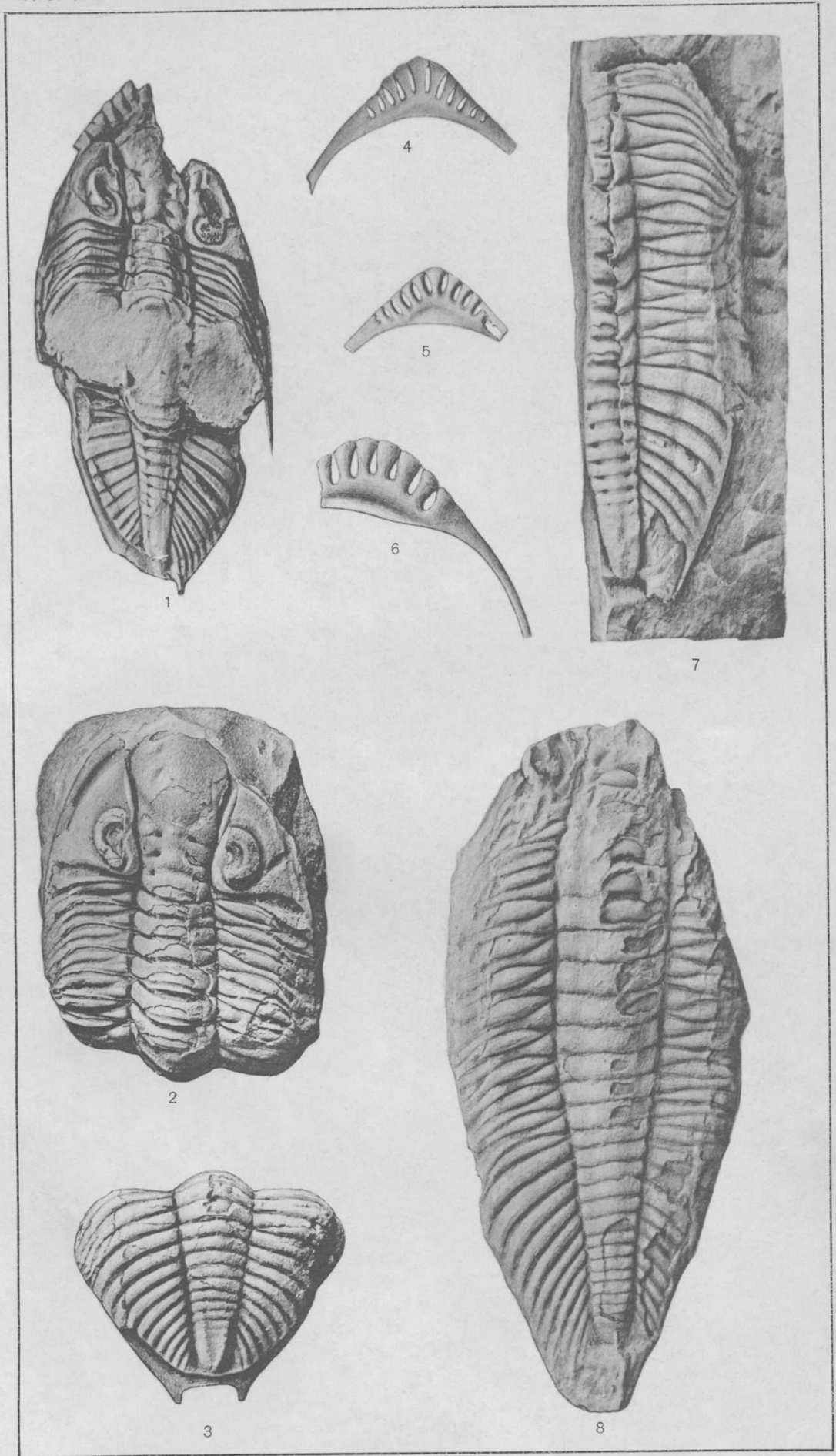

ONONDAGA FAUNA 
PLATE XIII. 


\section{PLATE XIII. \\ Lichas (ARges) contusus var. (p. 112).}

Figure 1. Fragmentary cephalon, $\times 5$. Mendota, Va.

CyPhaspis cf. STephanophora (p. 111).

Figure 2. Fragmentary glabella, $\times 5$. Berkeley Springs, W. Va.

\section{ACIDASPIS CALLICERA (p. 112).}

Figure 3. Fragmentary glabella, showing imperfectly the notched anterior margin, $\times 5$. Blair County, $\mathrm{Pa}$.

4. Nearly complete glabella, $\times 3$. Blair County, Pa.

5. Natural cast of a portion of the free cheek, showing spinose margin, $\times 3$. Mendota, Va.

6. Natural mold of the interior of a free right cheek, $\times 3$. Berkeley Springs, W. Va.

7. Natural cast of the interior of a right cheek, showing bases of marginal spines and a portion of the long genal spine. New Bloomfield, Pa.

8. Genal spine and a part of the cheek. New Bloomfield, Pa.

9. Wax cast of a pygidium, showing spines but not the tuberculous surface, $\times 2$. New Bloomfield, Pa.

10. Fragmentary pygidium, showing tuberculous surface, $X 5$. Mendota, Va.

\section{Phathonides gemmeus (p. 111).}

FIG URE 11. Fragmentary pygidium. The light-colored portion is restored, $\times 5$. Mendota, Va.

1.2. Natural cast of the interior of a pygidium doubtfully referred to this species, $\times 2$. New Bloomfield, Pa.

140 

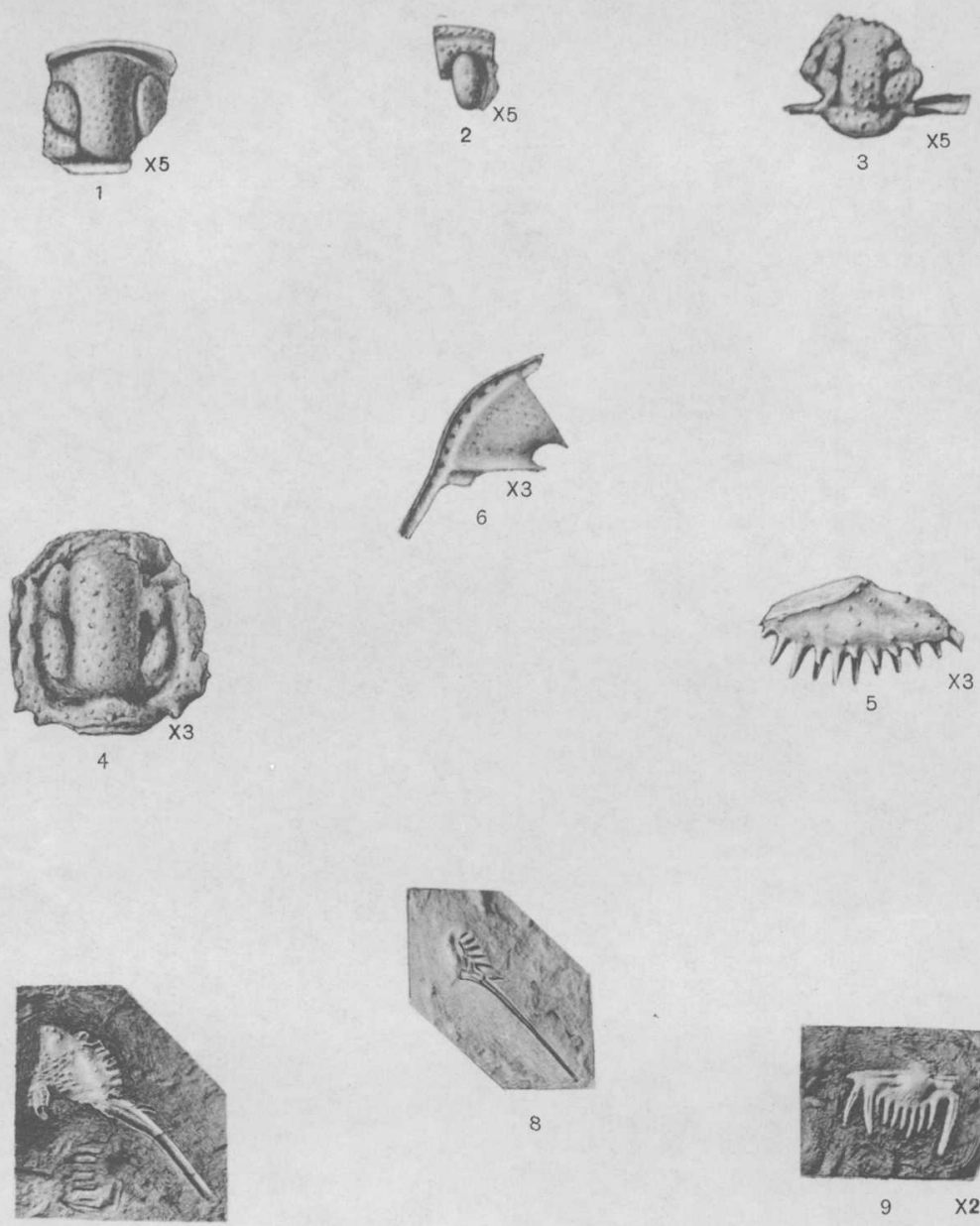

8

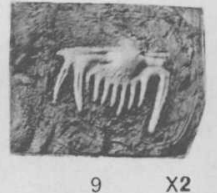

7

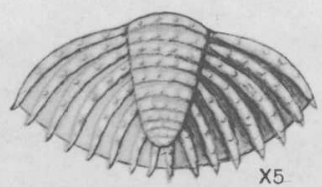

11
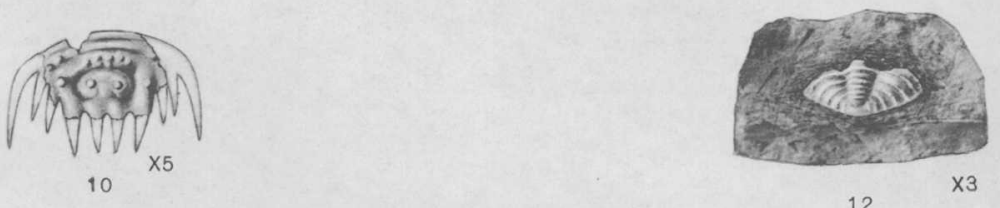


\section{INDEX.}

[Names in italic are synonyms; figures in italic denote fllustrations; figures in black face denote descriptions.]

Acidaspis callicera.

( Teratapsis) eriopsis. sp.

Actinopteria muricata. sp.

Agoniatites expansus................ 37, 107, 182

Alinda, Pa., section at.................. 30

Ambocœlia nana.............. 31, 40,47,56,83,124 umbonata...................... 7,27 , $30,31,33,34,36,37,39,41,44,45,49,56,83$

Anomia reticularis.

80

Anoplia nucleata. $30,33,36,40,41,44,45,49,56,73-74,124$ sp....

Anoplotheca acutiplicata.............. 7,10, $22,23,28,31,33,34,35,37,39,40$, $41,42,43,44,45,46,47,56,84,126$ camilla................... 33, 34, 37, 44,56, 85 concava.

A parchites.

A saphus aspectans. selenurus.

Ashburner, C A.

A trypa acutiplicata.

concinna........................... 86

impressa............................ 29

nasuta............................ 85

reticularis......................... 7 , $21,23,27,30,33,34,49,56,80,124$

spinosa............................. 21

unisulcata............................ 85

Aulopora sp........................ 47,52

A vicula equilatera........................ 93

fragilis.............................. 90

lxvis............................... 95

muricata........................... 92

Aviculopecten equilatera............ 39, 58, 93, 180 fragilis.

B.

Bactrites aciculum. 27,32, 34,37, 39, 44, 47, 54, 104, 138 sp................................ 33 tenuicinctum........................ 104

Baker, Luke, acknowledgement to......... 29 Bassler, R. S., reference to.......... 10, 36, 52, 60

Bellerophon expansus................... 102 leda........................ 28,44,101,180 pelops........................... 34,59,102 sp................................ 34, 101

Bells Valley, Va, section at .
Berkeley Springs, w. Va., section at........ $\quad 40$

Big Stone Gap, sections at.............. 50-53

Blothrophyllum americanum.............. 52 decorticatum.................... 52,67,118

Bollia lata ........................... 113 obesa........ 33, 34, 36, 37,39,44, 49, 60, 114, 198 symmetrica......................... 113 ungula......................... 30 ,

$31,33,34,36,37,40,42,44,45,47,60,113,192$

Brachiopoda.................. 20,56-57,69-86 Bryozoa.......................... 55,68-69

Buchiola halli.................. 44, 47, 48, 58, 88 retrostriata....................... 37,44 sp.............................. 40,44 speciosa........................ 43,48,88 Bythocypris favulosa.... 30,32,44, 45, 49,60, 114, 192

\section{C.}

Calymene bufo var. rana ................. 107 odontocephala........................ 109

Camarotœchia sp...................... 27,49 Campbell, M. R., reference to......... 9, 18, 49, 50 Canoe Creek, section near................. 34

Cardiola dichotoma....................... 96 ratians............................. 97

Catawba Mountain, section on............. 46-47 Cephalopoda...................... 59, 106-107 Chonetes arcuata......................... 73 buttsi..................... 33, 34,56, 72, 182 carinatus.......................... 48 (Eodevonaria) arcuatus......... 49,56, 73, 120 hemispherica........................ 70 hemisphericus.............. 27, 31,56, 70,120 laticosta............................ 71 lineata............................. 49 mucronatus...................... 24, $27,28,32,34,37,44,47,48,49,56,62,71,120$ rugosus.................... $37,56,72-73,128$ scitulus............................. 40 setigerus.................. 34, 40,56,71, 120 sp..................24,29,31,33,34,39,41

Cladopora bifurca........................ 52 crassa............................... 52 expiata............................. 52 sp............................. 24, 45,47

Clarke, J. M., acknowledgment to......... 110 reference to............... 17,60,63,88,91,111 Claypole, E. W., quotation from.......... 6,7 reference to........................ 15,29, 31

Clifton Forge, Va., sections at. ............ 45

Coelenterata........................... 66-67 


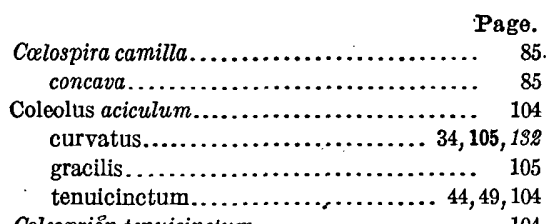

Coleoprion tenuicinctum.................. 104

Conchita rhomboidalis................... 77

Conocardium cuneus var. nasutum ... 49, 58,91-92 nasutum............................. 91 sp........................ 49

Conodonts $\ldots \ldots \ldots \ldots \ldots \ldots \ldots \ldots \ldots .36,59,67,118$

Conolichas hispidus................ 39,61, 111

Conularia sp . ................ 32,33,45,106 undulata .......................... 106

Corals . ........................... 20

Coscinium sp.................... 55,68 striaturum ....................... 27

Cranæna romingeri.......... 29,39,44,56, 86, 128

Craniella hamiltoniæ. . . . . . . . . . . . . . 39,41

Craterellina ...................... 36,60

Crinoidea........................ 45,49,55

Cryphæus boothi var. calliteles..... 39, 108, 134,186 calliteles.

108

Cumberland, Md., section at............. 36-38

Cyphaspis stephanophora...... 41,61,111-112,140

Cypricardella bellistriatus. ............. 59,63

Cypricardinia indenta........ 49,58,94-95, 128

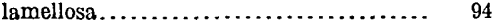

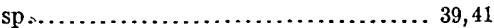

Cypricardites indenta.................... 94 subalata......................... 93

Cyrtia hamiltonensis.................. 81

Cyrtina hamiltonensis .......... 24, 30,56, 81, 124

Cyrtoceras sp......................... 21

Cystiphyllum americanum . ......... 52, 67, 118 cylindricum..................... 67 sp........................... 24 sulcatum....................... 52

Cystodictya gilberti: .............. 55,68

D.

Dälmanella lenticularis

30 , $31,36,39,40,41,42,45,47,56,79,124$

Dalmania ægeria...................... 109

Dalmanites 2 geria.................... 110

anchiops........................ 112

aspectans............................ 21

(Coronura) aspectans......... 34,61, 109, 194

(Cryphæus) boothi var. calliteles.... 33, 61, 108 myrmecaphorus.................. 7

(Odontocephalus) ægeria.............. 109 selenurus. ......................... 109

selenurus....................... 109

sp. . . . ............... 31,40,61, 112, 186

Darton, N. H., reference to .......... 9, $16,38,39$

Davidsonia bouchardiana............... 78

Davis, W. J., reference to ............... 66

Delthyris acuminata.................... 81 fimbriatus ...................... 82 prora ........................... 81

Dendropora neglecta $\ldots \ldots \ldots \ldots \ldots \ldots \ldots \ldots . \ldots 2$

Devonian formations, differentiation of changes in.

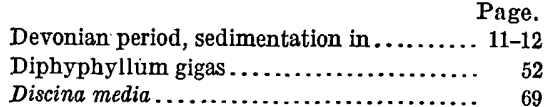

E.

Eaton, Amos, quotation from ............ 5

Echinodermata........................ 67

Enchostoma sp .................... 37, 105-106

Euomphalus sp....................... 37

Euthydesma......................... 37

\section{F.}

Falling Spring, Pa., section at............. 28-29

Favosites canadenses.................... 52 emmonsi.......................... 52

epidermatus........................ 52

hemisphericus....................... $\quad 52$

turbinatus.......................... 52

Fenestella biseriata..................... 21 parallella.......................... 68

(Polypora) distans................... 27,68 hexagonalis....................... 69

sp ........................... 24, 27,55,68 Fort Seybert, W. Va., Onondaga limestone at. 41-42

\section{G.}

Gastropoda..................... 59,97-103

Glyptocardia speciosa.................... 88

Goniatites discoideus..................... 106

expansus......................... 107

sp $\ldots \ldots \ldots \ldots \ldots \ldots \ldots \ldots \ldots \ldots \ldots \ldots \ldots \ldots \ldots, 47,44$

vanuxemi .......................... 107

Grabau, A. W., reference to.. $10,21,22,50,56,58,61$

Grammysia sp ....................... 37, 58, 87

subarcuata $. \ldots \ldots \ldots \ldots \ldots \ldots \ldots \ldots . . . \ldots \ldots$

Grimsley, G. P., reference to ............. 38

H.

Hall, James, quotation from............. 95,

$96,98,99,100,101,102,104$

reference to ...................... $58,83,111$

Hancock, Md., section at............... 35-36

Hayfield, Va., outcrops at................ 42-43

Hederella sp ......................... 55, 68

Elelderberg Mountains; Onondaga limestone

in, section of ................ 20-21

Heliophylium annulatum................ 52

halli.............................. 52

Hollidaysburg, Pa., section at.............. 33

Hovey, Dr. E. O., acknowledgment to...... 110

Hyolithes aclis ...................... 34, 39, 105

principalis ....................... 34,105

I.

Iron-ore beds, section in $30-31$

J.

Jones, T. Rupert, quotation from...... 113, 114, 115 reference to

K.

Kindle, E. M., reference to ......... 10,18, 19, 50

Klœdenella clarkei...................... 52 
L.

Lehigh River, sections on ................ 26-27

Leiopteria bigsbyi. lævis. $37,58,95-98,180$

Leiorhynchus limitare nysius.....

$27,28,35,37,40,44,80$

reperditia alta. subrotunda......... 33, 34,41, 49, 60, 115-116, 182

Leptæna nucleata. rhomboidalis............21, 23, 24, 28,56,77,78

Leptænisca australis..... 30,36,41,47,56,78-79, 128 concava............................. 79 rugata............................. 78

Leptodesma sp.......................... 44

Leptostrophia perplana......... 30,41, 75, 118,120

Lesley, J. P., reference to . . ...... 7, 23, 24, 25, 26, 27

Lichas (Arges) contusus. . ......... 49,61,112,140 (Conolichas) hispidus.................. 111

Lingula ligea................ $34,39,53,56,69,118$ sp.............................. 23,33

Little Moccasin Gap, section at............ 48-49

Little Walker Creek, section near........... 47-48

Loxonema hamiltonix............ 37,39, 100, 130 pexata........................... 34,100 sp.............................. 3i, 33

Lunulicardium curtum........... 39,58,89-90,128 fragile.

M.

McVeytown, Pa., section at. ............. 31-32 Martinia sp........................... 32,86

Maryland, Onondaga limestone in........ 14, 15-16 Onondaga limestone in, stratigraphy of. . 35-38

Maysville, W. Va., Onondaga limestone at. . $\quad 41$

Mendota, Va., outcrop at................ 49-50

Meristella nàsuta.................. 49, 56, 85, 128 unisulcata.......................... 21

Modiomorpha myteloides................. 59,63 subalata.................. 37, 58,93-94, 130 sp................................. 33

Moorefield, W. Va., Onondaga limestone at.

Mountain Grove, Va., section at.

N.

Naticopsis sp ..............34,37,39,47, 98, 180 New Bloomfield, $\mathrm{Pa}$., sections near ......... 29-30 New Jersey, Onondaga limestone in, stratigraphy of

New York, Onondaga limestone in, stratigraphy of.................. 20-22

Nucleospira concinna.. $30,36,37,40,41,44,56,86,128$

Nucula bellatula. corbuliformis........ 31, 39,41, 44, 58, 88-89, 128 sp................................ 34

Nuculites constricta..................... 87 modulatus............. 31, 37, 39, 44, 56, 89, 128 oblongus.

0 .

Octonaria stigmata.......... 31, 34, 43, 60, 115, 192 Odontocephalus ægeria................. 23, $33,45,47,49,61,109-111,134,186,198$ cristata........................... 33 selenurus...............23,29, 32,61,109,198 sp. 30
O'Harra, C. C., reference to $P a g e$.

Onondaga fauna, age of.................. 53-63

biologic groups in................... $54-62$ paleogeographic significance of.......... 63-65

Onondaga limestone, distribution of ........ 5-11 importance of, as a datum plane........ 5 recognition of....................... 14-19 stratigraphic relations of................ 11-19

Orbicula lodensis ........................... 70 lodiensis.......................... 56, 70

Orbiculoidea lodiensis var. media............ 32 , $34,37,39,40,44,45,46,56,69,118$ sp............................ 30,34,45

Oriskany sandstone, distribution of, in Pennsylvania .................... 23-34

Orthis lenticularis ......................... 79

limitaris........................... 80

perversa............................ 76

umbonata............................ 83

vanuxemi........................... $\quad 79$

Orthisina alternata....................... 76

Orthoceras aciculum....................... 104

subulatum............................ 34, 106

sp.............................. 31,39

Orthonota sp......................... 44

Ostracoda............... 21, 30,34, 45, 60,113-116

P.

Palæoneilo constricta.......... 34, 37, 58, 87-88, 128

Panenka alternata...................... 58, 97 dichotoma.................... 39, 58,96,128 multiradiata....................... 58,97 Paracardium doris....................... 48

Pararca............................. 43

Parodiceras discoideum............... 47,48, 106

Pelecypoda..................... 58-59;87-97

Pennsylvania, Onondaga limestone in ...... 14-15

Onondaga limestone in, stratigraphy of. . 23-34

Pentagonia unisulcata .......... 24,28, 49,56,57,85

Pentamerella arata..................... 21

Phacops cristata...................... 30 , $36,39,40,42,43,45,61,107-108,194$ cristata var. pipa.................... 21 $23,28,30,34,41,47,48,49,61,108,194$ rana....................... 44,61, 107,194 sp.............................. 36 Phæthonides gemmæus...........49,61,111, 140 Pholidops areolata....... 33, 34, 37, 39, 49,56,70, 118 sp.............................. 45 Pholidostrophia pennsylvanica........... 37 $39,41,56,74-75,124$

Platyceras dumosum.................... 21 rictum............................ sp.................... 23, 28, 34,39, 45,99 thetis............................. 99, 180

Platyostoma euomphaloides............... 97 lineata.............................. 98 turbinata...................... 97-98,190

Pleurodictyum sp.................66-67, 118

Pleurotomaria crassa............. 34, 102-103, 130

sp................................ 44 sulcomarginata.................... 103 trilix .......................... 45, 102 Polygnathus sp..................... 36,67,118 
Page.

Polypora distans...................... 55,68 hexagonalis...................... 27,55, 69

Procteria papillosa...................... $\quad 66$ sp................................. 45

Productella navicella............... 27,56, 78, 124 sp............................... 33

Productus navicellus..................... $\quad 78$ pustulosus.......................... 77

Prosser, C. S., quotation from ............ 16 reference to............... 8, 10,17, 20,24, 35

Pterinea consimilis..................... 91 flabella........................... 59 sp...................... 49,58,91,180

Pterochænia fragilis..........47,48,58,90-91,128 Pteronites lævis....................... 95

Pteropoda....................... 59, 103-106

Ptilodictya (Stictopora) gilberti............. 68

R.

Rees Tannery, W. Va., section at

Reticularia fimbriata.

(1)......... 40 modesta.

$37,56,82$

Rhipidomella vanuxemi................ 23, $30,31,36,39,49,56,79-80,124$

Ridgeville, $W$. Va., section at............ 39-40 Romney, W. Va., section at............... 41

Romney formation, Onondaga shale member of, description of.............. 14

Romney shale, lithologic character of ....... 15-18 relations of......................... 35 stratigraphy of, in Virginia............ 42

Rowe, R. B., reference to............... 20,21

\section{S.}

Saylorsburg, Pa., section at.............. 25-26 Schizobolus concentricus............. 48,49,50,53 truncatus.

Schizodus sp.

schuchert, Charles, reference to.

8,10 $17,50,52,57,78$

Schuchertella pandora $23,49,56,76,120$ perversa................... 28,34,56,76-77 Schuylkill River, section on ..............27-28 Selinsgrove, Pa., section near............. 31 Shenandoah Alum Springs, section at...... 43

Shively, J. W., acknowledgment to ......... 30 Spirifer acuminatus............ 28, 56,57, 81, 126 audaculus.

$28,56,57,81,126$ disparalis............................ 49 duodenaria........................... 21

fimbriata.......................... 49

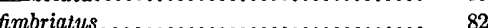

modestus............................ 82

macra.............................. 21

varicosa........................... 82

varicosus............... $23,28,49,56,82,126$

Spirophiton cauda-galli................. 20

Stevenson, J. J., reference to............... 9

Stictopora gilberti........................ 27

sp.................................. 49

Streptorhynchus pandora.................. $\quad 76$

Stribling Springs, Va., exposure at......... 43

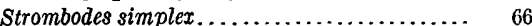

Strophalosia truncata ................ 27, 29, $31,32,34,36,37,39,40,44,45,49,56,77,124$ tropheodonta concava.................... 21 inequistriata................. 30,34, 56,76,120 patersoni..................... 49,56,75, 180 perplana......................... 27,56 sp................................. $\quad 49$

textilis............................. 21

Strophomena inæquistriata ................. $\quad 76$

mucronata.......................... $\mathbf{7 1}$

perplana........................... 75

- (Strophodonta) patersoni............... 75 pustulosa........................... $\quad 77$

rugata............................ 78

setigera............................. $\quad 71$

undulosa............................ $\quad 77$

Stroudsburg, Pa., section at.............. 24-25

Styliola fissurella......................... 103

Styliolina fissurella..................... 27,

$28,30,31,32,33,34,35$,

$36,40,41,44,45,49,54,103$

Swartz, C. K., acknowledgment to.......... 36

Swatara Creek, section on................. 28

Syringopora hisingeri.................... 52

maclurei...............................

T.

Taff, J. A., reference to $\ldots \ldots \ldots \ldots \ldots \ldots \ldots, 16,38$

Tentaculites.......................... 21,34

bellulus........................ 24,28, 104

fissurella........................... 103

gracilistriatus................ 44,47,103,132

scalariformis.............. 49,59, 103-104,132

sp................................. 49

Terebratula acuminatissima............... $\quad 81$

romingeri........................... 86

Tonoloway, Md., section at................ 36

Trilobita............. 30,33,34,54,60-62, 107-112

Tropidoleptus carinatus ............. $38,40,59,63$

U.

Ulrich, E. O., quotation from............. 114,115 reference to $\ldots \ldots \ldots \ldots \ldots \ldots \ldots \ldots \ldots, 36,60$

Ulrichia conradi.................. 31, 60,115,198

Upper Reese, Pa., section near............ 32-33

$$
\mathrm{V} \text {. }
$$

Van Ingen, Gilbert, reference to.......... 22, 61

Vermes............................... 67-68

Vermipora fasciculata................... 52

Virginia, Onondaga fauna in.............. 42-53

Onondaga limestone in............. 14, 15-19

W.

Weller, Stuart, reference to........ 11, 22, 23, 53,63 West Virginia, Onondaga limestone in, strati-

graphy of................... 38-42

White, I. C., reference to................ 15, 24, 26, 31

Williams, H. S., quotation from........... 9 reference to...................... 10, 18,50

Willis, Bailey, reference to................ 8

Wood, Elvira, reference to................. 50,63

Z.

Zaphrentis cornicula.................. 21,52

gigantea.......................... 21

prolifica........................... 52

simplex................. 24, 30, 45, 47,66, 118

sp.................. $23,27,34,40,45,47,49$ 